\title{
EPIGENOMIC ACTIONS OF ENVIRONMENTAL ARSENICALS
}

by

\author{
Paul Leamon Severson
}

A dissertation Submitted to the Faculty of the

DEPARTMENT OF PHARMACOLOGY AND TOXICOLOGY

In Partial Fulfillment of the Requirements

For the Degree of

DOCTOR OF PHILOSOPHY

In the Graduate College

THE UNIVERSITY OF ARIZONA

2013 


\section{THE UNIVERSITY OF ARIZONA GRADUATE COLLEGE}

As members of the Dissertation Committee, we certify that we have read the dissertation prepared by Paul Leamon Severson, titled Epigenomic Actions of Environmental Arsenicals and recommend that it be accepted as fulfilling the dissertation requirement for the Degree of Doctor of Philosophy.

Date: June 20, 2013

Bernard W. Futscher, Ph.D.

Date: June 20, 2013

Mark A. Nelson, Ph.D.

Date: June 20, 2013

Walter T. Klimecki, Ph.D.

Date: June 20, 2013

Catharine L. Smith, Ph.D.

Date: June 20, 2013

Yin Chen, Ph.D.

Final approval and acceptance of this dissertation is contingent upon the candidate's submission of the final copies of the dissertation to the Graduate College.

I hereby certify that I have read this dissertation prepared under my direction and recommend that it be accepted as fulfilling the dissertation requirement.

Dissertation Director: Bernard W. Futscher, Ph.D.

Date: June 20, 2013 


\section{STATEMENT BY AUTHOR}

This dissertation has been submitted in partial fulfillment of the requirements for an advanced degree at the University of Arizona and is deposited in the University Library to be made available to borrowers under rules of the Library.

Brief quotations from this dissertation are allowable without special permission, provided that an accurate acknowledgement of the source is made. Requests for permission for extended quotation from or reproduction of this manuscript in whole or in part may be granted by the head of the major department or the Dean of the Graduate College when in his or her judgment the proposed use of the material is in the interests of scholarship. In all other instances, however, permission must be obtained from the author. 


\section{ACKNOWLEDGEMENTS}

Thank you to my mentor Dr. Bernard Futscher. Your good character made each of our talks enjoyable and made me glad to come to the lab each day. My life has changed immensely since I joined your lab, and you always gave me the flexible support that I needed. Thank you for helping me to see things that I could not see before, even when they weren't the prettiest.

To my graduate committee, thank you for listening, caring and supporting me as I progressed through the graduate school process. I would also like to thank all the members of the Futscher Lab for their support and help throughout the years. It was a pleasure to work with you and I am proud to be a part of the lab family. In particular, to Dr. Lukas Vrba, thank you for spending your time and energy to teach me new skills that I would have never acquired without your assistance and for giving me a new perspective on science.

To my parents, thank you for working so hard to give me a wonderful life. I am so happy to be your son. To all the other Seversons and Weeds, there are many of you, but each of you has influenced me for the better. Thank you for being my dream family.

To my dear wife and children, thank you for being with me, laughing with me, and loving me. I believe that knowledge is power, and knowing that I have you to share my life with gives me motivation and power to confront life's challenges. I want to make the world a better place for you because you make it a much better place for me. 


\section{TABLE OF CONTENTS}

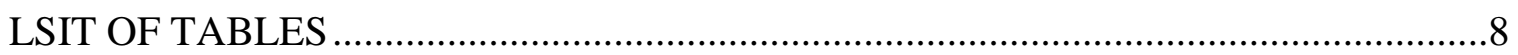

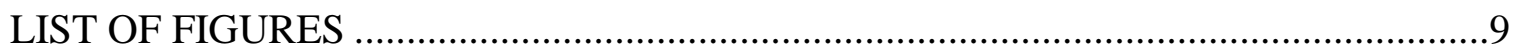

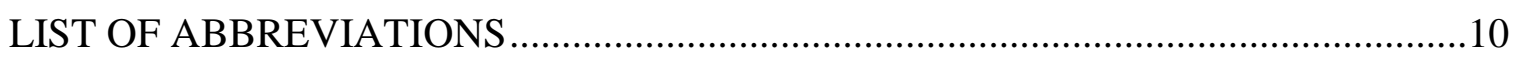

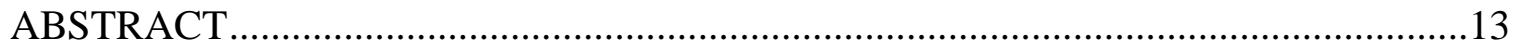

CHAPTER 1: INTRODUCTION TO EPIGENETIC RESEARCH WITH

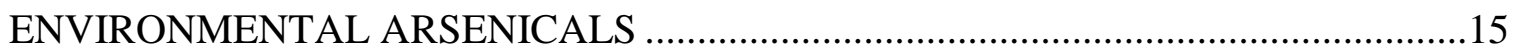

Basic Background on Arsenic ...........................................................................15

Arsenicals in Relation to Human Health .....................................................................

Arsenical Mechanisms of Action ...........................................................................18

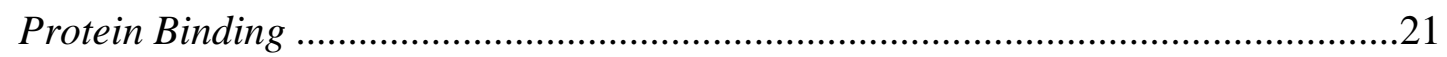

Reactive Oxygen Species (ROS) ………………………..............................22

DNA Damage ..............................................................................................22

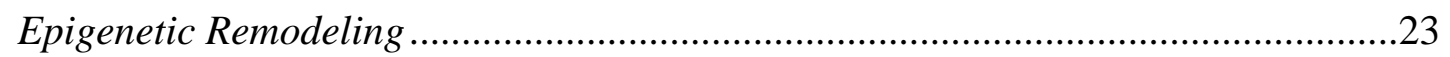

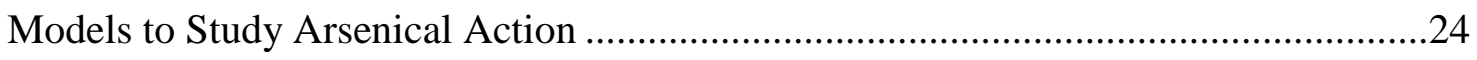

Epigenetic Mechanisms and their Roles ...............................................................26

Epigenetic Effects of Arsenicals .............................................................................

Research Questions of the Present Studies and their Rationale ....................................39

CHAPTER 2: AGGLOMERATES OF ABERRANT DNA METHYLATION ARE ASSOCIATED WITH TOXICANT-INDUCED MALIGNANT

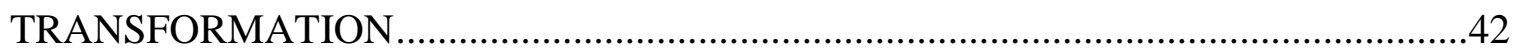

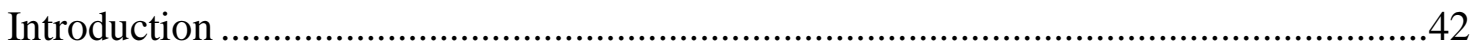

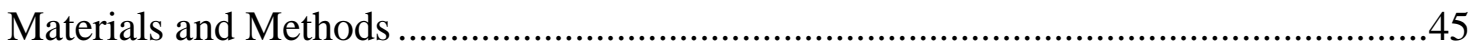

Cell culture and sample acquisition …………………………...............................45

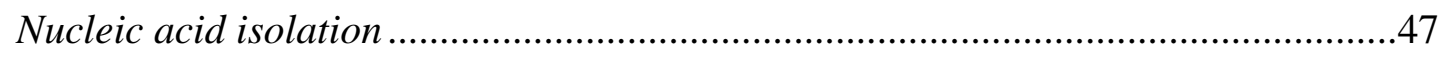

MeDIP coupled to microarray (MeDIP-on-Chip) ……………………………....47

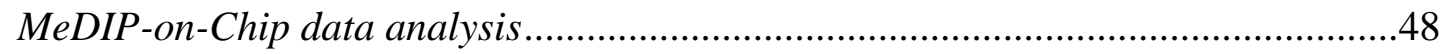

Detection of agglomerates and regions enriched with stem cell domains ..................49

MassARRAY EpiTYPER ${ }^{T M}$ DNA methylation analysis..............................................

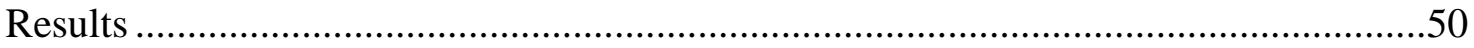




\section{TABLE OF CONTENTS - Continued}

Malignant transformation produces hundreds of DMRs in distinct models ..............50

Agglomerates of aberrant DNA methylation in toxicant-transformed models...........61

Association of agglomerative DMRs with hESC histone modification domains........68

Discussion

CHAPTER 3: COORDINATE H3 LYSINE 9 AND DNA METHYLATION

SILENCING OF ZNF CLUSTERS DURING TOXICANT-INDUCED

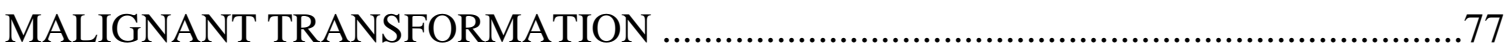

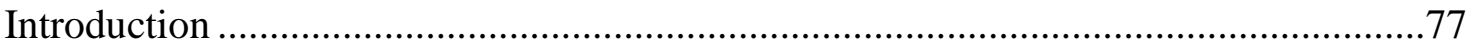

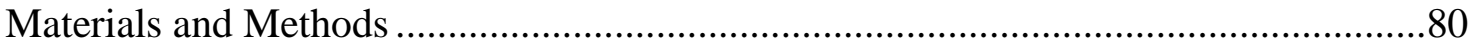

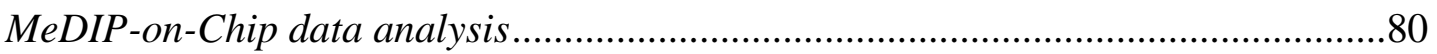

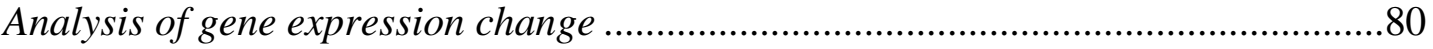

Merging DNA methylation data with gene expression data ....................................81

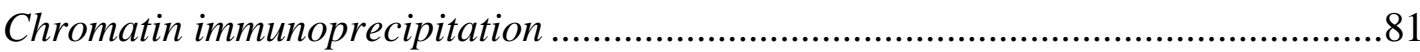

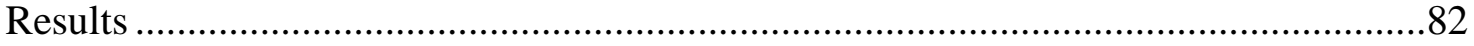

Hypermethylated genes share common ontologies ................................................84

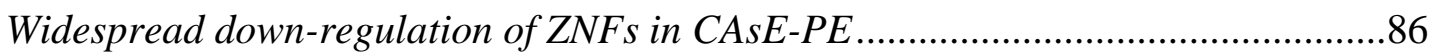

A negative correlation between DNA methylation and gene expression is driven by hypermethylation of ZNF gene promoters ..........................................................8

H3K27me3 domains are silent targets of aberrant DNA methylation ......................91

ZNF gene clusters associate with hESC H3K9me3 domains and are silenced by

DNA hypermethylation

Aberrant spreading of $H 3 \mathrm{~K} 9 \mathrm{me} 3$ is linked to DNA methylation and gene silencing

Discussion 101

CHAPTER 4: CURRENT PERSPECTIVES AND FUTURE DIRECTIONS ..............105

Current Perspectives on Arsenical-Associated Epigenetic Dysfunction......................105

Critical Processes Altered by Arsenical Exposure ...................................................106

Diverse diseases with potentially common targets ..................................................106

Energy deregulation, mitochondrial dysfunction and ROS ..................................107 


\section{TABLE OF CONTENTS - Continued}

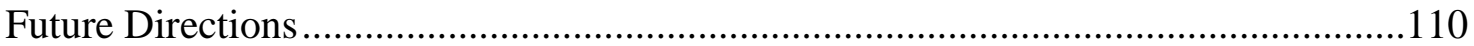

ChIPs to identify and characterize H3K9me3 boundaries within ZNF genes .........110

Challenging the H3K9me3 boundaries to identify probable targets.......................111

Investigating potential outcomes of widespread ZNF gene silencing .....................112

APPENDIX A: SUPPLEMENTAL INFORMATION FOR CHAPTER 2 ...................114

APPENDIX B: SUPPLEMENTAL INFORMATION FOR CHAPTER 3 ...................119

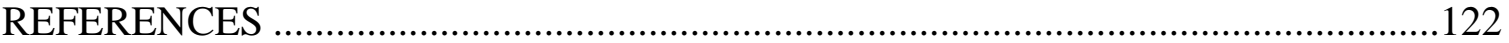




\section{LIST OF TABLES}

Table 1.1 Summary of studies testing the epigenetic effects of arsenical exposure in human populations and human cell lines........................................................ 32

Table 2.1 Cell lines and samples analyzed by MeDIP-on-ChIP ….................................51

Table 2.2 Genomic regions of arsenic-induced agglomerative DNA

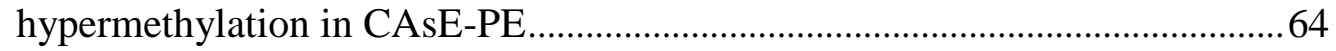

Table 2.3 Hypermethylated gene family clusters in malignant samples ...........................65 


\section{LIST OF FIGURES}

Figure 2.1 Origins of the toxicant-transformed cell lines and their relative DNA methylation profiles assessed by multidimensional scaling..... .52

Figure 2.2 Overlap of hyper or hypomethylated probes between groups ......................57

Figure 2.3 Number of differentially methylated regions between groups .....................60

Figure 2.4 Agglomerative DMRs and hESC H3K9me3 domains in CAsE-PE..............62

Figure 2.5 Heatmap view of the DNA methylation changes in the PCDHG cluster of CAsE-PE

Figure 2.6 Percent of hypermethylated probes occurring within hESC H3K27me3 or hESC H3K9me3 domains

Figure 3.1 Distribution of MeDIP-on-Chip probes relative to the nearest TSS and Venn diagram showing the overlaps of hESC H3 K27/K9 trimethylated domains with hypermethylated genes

Figure 3.2 Confirmation of DNA methylation changes by MassARRAY ${ }^{\mathrm{TM}}$

Figure 3.3 Plot of the Affymetrix human gene expression dataset and confirmations by QRT-PCR

Figure 3.4 Gene expression change by DNA methylation change in CAsE-PE relative to RWPE-1

Figure 3.5 Chromatin immunoprecipitation of H3K27me3 target genes

Figure 3.6 Venn diagram of hypermethylated or down-regulated ZNF genes in cluster 19.13

Figure 3.7 Gene expression and DNA methylation changes plotted across chromosome 19 and part of chromosome 5

Figure 3.8 Chromatin immunoprecipitation of 5' and 3' ends of ZNF genes in ZNF gene cluster 19.13.

Figure 3.9 Chromatin immunoprecipitation at ZNF560, ZNF300 and ZNF454 .100

Figure 3.10 TCGA prostate adenocarcinoma expression and methylation datasets .104 


\section{LIST OF ABBREVIATIONS}

\begin{tabular}{|c|c|c|}
\hline$\mu \mathrm{g} / \mathrm{L}$ & - & micrograms per liter \\
\hline$\mu \mathrm{M}$ & - & micro molar \\
\hline $5 \mathrm{hmc}$ & - & 5-hydroxymethylcytosine \\
\hline $5 \mathrm{mc}$ & - & 5-methylcytosine \\
\hline As PM & - & arsenic particulate matter \\
\hline $\mathrm{As}_{2} \mathrm{O}_{3}$ & - & arsenic trioxide \\
\hline $\mathrm{As}^{\mathrm{III}}$ & - & arsenite \\
\hline $\mathrm{As}^{\mathrm{V}}$ & - & arsenate \\
\hline BPE & - & bovine pituitary extract \\
\hline $\mathrm{C} 2 \mathrm{H} 2$ & - & Cys2 His2 zinc finger motif \\
\hline $\mathrm{Cd}^{\mathrm{II}}$ & - & cadmium \\
\hline $\mathrm{CpG}$ & - & cytosine guanine dinucleotide \\
\hline CTCF & - & CCCTC-binding factor (zinc finger protein) \\
\hline DAPK & - & death-associated protein kinase 1 \\
\hline DBCCR1 & - & deleted in bladder cancer chromosome region candidate 1 \\
\hline $\mathrm{DMA}^{\mathrm{III}}$ & - & dimethylarsinous acid \\
\hline $\mathrm{DMA}^{\mathrm{V}}$ & - & dimethylarsinic acid \\
\hline DMEM & - & Dulbecco's modified eagles medium \\
\hline DMR & - & differentially methylated region \\
\hline DNMT & - & DNA methyltransferases \\
\hline EGF & - & epidermal growth factor \\
\hline FDA & - & Food and Drug Administration \\
\hline FDR & - & false discovery rate \\
\hline G0S2 & - & G0/G1switch 2 \\
\hline G9a & - & euchromatic histone-lysine N-methyltransferase 2 or EHM] \\
\hline
\end{tabular}




\section{LIST OF ABBREVIATIONS - Continued}

\begin{tabular}{|c|c|c|}
\hline $\mathrm{H}_{2} \mathrm{AXPO}_{4}$ & - & histone $\mathrm{H} 2 \mathrm{AX}$ phosphorylation \\
\hline $\mathrm{H} 3 \mathrm{Ac}$ & - & histone $\mathrm{H} 3$ acetylation \\
\hline H3K27me3 & - & histone $\mathrm{H} 3$ lysine 27 trimethylation \\
\hline $\mathrm{H} 3 \mathrm{~K} 4 \mathrm{me} 2$ & - & histone $\mathrm{H} 3$ lysine 4 dimethylation \\
\hline $\mathrm{H} 3 \mathrm{~K} 4 \mathrm{me} 3$ & - & histone $\mathrm{H} 3$ lysine 4 trimethylation \\
\hline H3K9Ac & - & histone $\mathrm{H} 3$ lysine 9 acetylation \\
\hline H3K9me2 & - & histone H3 lysine 9 dimethylation \\
\hline H3K9me3 & - & histone $\mathrm{H} 3$ lysine 9 trimethylation \\
\hline $\mathrm{H} 3 \mathrm{~S}_{10 P O}$ & - & histone $\mathrm{H} 3$ serine 10 phosphorylation \\
\hline H4K16Ac & - & histone $\mathrm{H} 4$ lysine 16 acetylation \\
\hline HBSS & - & Hank's balanced salt solution \\
\hline HERV & - & human endogenous retrovirus \\
\hline hESC & - & human embryonic stem cells \\
\hline HMEC & - & human mammary epithelial cells \\
\hline HPV18 & - & human papilloma virus 18 \\
\hline KAP1 & - & KRAB-associated protein 1 or TRIM 28 or TIF1B \\
\hline KRAB & - & krüppel associated box \\
\hline K-SFM & - & keratinocyte serum free media \\
\hline LRES & - & long range epigenetic silencing \\
\hline MDS & - & multidimensional scaling \\
\hline MeDIP & - & methyl-DNA immunoprecipitation \\
\hline MMA $^{\text {III }}$ & - & monomethylarsonous acid \\
\hline $\mathrm{MMA}^{\mathrm{V}}$ & - & monomethylarsonic acid \\
\hline MNU & - & $\mathrm{N}$-methyl-N-nitrosourea \\
\hline P16 & - & cyclin-dependent kinase inhibitor $2 \mathrm{~A}$ \\
\hline
\end{tabular}




\section{LIST OF ABBREVIATIONS - Continued}

$\begin{array}{lll}\text { PBL } & - & \text { peripheral blood leukocytes } \\ \text { PBMC } & - & \text { peripheral blood mononuclear cells } \\ \text { ppb } & - & \text { parts per billion } \\ \text { PRSS3 } & - & \text { protease, serine, } 3 \\ \text { Q-PCR } & - & \text { quantitative or real-time PCR } \\ \text { QRT-PCR } & - & \text { quantitative, reverse transcription PCR } \\ \text { RASSF1A } & - & \text { Ras association (RalGDS/AF-6) domain family member 1 } \\ \text { Rb } & - & \text { retinoblastoma 1 gene } \\ \text { ROS } & - & \text { reactive oxygen species } \\ \text { SEM } & - & \text { standard error of the mean } \\ \text { SETDB1 } & - & \text { SET domain, bifurcated 1 or ESET } \\ \text { SUV39H } & - & \text { suppressor of variegation 3-9 homolog 1 } \\ \text { SV40 } & - & \text { Simian virus 40 } \\ \text { TCA } & - & \text { - }\end{array}$




\begin{abstract}
Epigenetic dysfunction is a known contributor in carcinogenesis, and is emerging as a mechanism involved in toxicant-induced malignant transformation for environmental carcinogens such as arsenicals. In addition to aberrant DNA methylation of single genes, another manifestation of epigenetic dysfunction in cancer is agglomerative DNA methylation, which can participate in long-range epigenetic silencing that targets many neighboring genes and has been shown to occur in several types of clinical cancers. Using in vitro model systems of toxicant-induced malignant transformation, we found hundreds of aberrant DNA methylation events that emerge during malignant transformation, some of which occur in an agglomerative fashion. In an arsenitetransformed prostate epithelial cell line, the protocadherin (PCDH), HOXC and HOXD gene family clusters are targeted for agglomerative DNA methylation. Aberrant DNA methylation in general occurred more often within $\mathrm{H} 3 \mathrm{~K} 27 \mathrm{me} 3$ stem cell domains. We found a striking association between enrichment of $\mathrm{H} 3 \mathrm{~K} 9 \mathrm{me} 3$ stem cell domains and toxicant-induced agglomerative DNA methylation. Global gene expression profiling of the arsenite-transformed prostate epithelial cells showed that gene expression changes and DNA methylation changes were negatively correlated, but less than $10 \%$ of the hypermethylated genes were down-regulated. These studies confirm that a majority of the DNA hypermethylation events occur at transcriptionally repressed, H3K27me3 marked genes. In contrast to aberrant DNA methylation targeting H3K27me3 premarked silent genes, we found that actively expressed ZNF genes marked with H3K9me3 on their 3' ends, are preferred targets of DNA methylation linked gene silencing.
\end{abstract}


H3K9me3 mediated gene silencing of ZNF genes was widespread, occurring at individual ZNF genes on multiple chromosomes and across ZNF gene family clusters. At ZNF gene promoters, H3K9me3 and DNA hypermethylation replaced H3K4me3, resulting in a widespread down-regulation of $\mathrm{ZNF}$ gene expression which accounted for $8 \%$ of all the down-regulated genes in the arsenical-transformed cells. In summary, these studies associate arsenical exposure with agglomerative DNA methylation of gene family clusters and widespread silencing of ZNF genes by DNA hypermethylation-linked H3K9me3 spreading, further implicating epigenetic dysfunction as a driver of arsenicalinduced carcinogenesis. 


\section{CHAPTER 1: INTRODUCTION TO EPIGENETIC RESEARCH WITH ENVIRONMENTAL ARSENICALS}

\section{Basic Background on Arsenic}

Arsenic is a naturally occurring toxicant, ranking as the $20^{\text {th }}$ most common element in the earth's crust. It can be found in a variety of natural compounds in which the arsenic pertains to one of four valence states $(-3,0,+3$, and +5$)$. Arsenicals are found in rock, soil, water and the tissues of plants and animals (IARC 2004).

Humans are exposed to arsenic primarily via their drinking water and food, with other routes of exposure such as from air, soil and medications playing a minor role in the total human exposure. The most common forms of arsenic found in water are the pentavalent arsenate $\left(\mathrm{As}^{\mathrm{V}}\right)$ and trivalent arsenite $\left(\mathrm{As}^{\mathrm{III}}\right)$ (IARC 2004). Partly due to their common occurrence, these arsenical species pose the greatest threat to human health. Most of the arsenic that enters the body is As ${ }^{\mathrm{III}}$, which has been reported to enter cells through cell membrane glucose transporters and aquaporins (Liu 2002, Liu 2006), while $\mathrm{As}^{\mathrm{V}}$ enters cells through phosphate transporters (Villa-Bellosta and V. Sorribas 2010, Huang and T. C. Lee 1996). Humans are able to enzymatically metabolize the inorganic arsenicals through a series of reduction and methylation reactions which give rise to monomethyl and dimethylarsenic acids (MMA ${ }^{\text {III \& V }}$ and DMA ${ }^{\text {III \& V }}$ (Thomas 2007). Cytotoxicity assays have shown that the metabolite $\mathrm{MMA}^{\mathrm{III}}$ is up to 20 times more toxic than inorganic arsenite (Petrick 2000).

Arsenic is perhaps the world's most well recognized poison, used repeatedly throughout history for the intentional poisoning of people in all stations. This has earned 
it the title "Poison of Kings and King of Poisons (Vahidnia 2007)." In contrast to its toxic effects, various forms of arsenic have been used for centuries as therapies for a wide range of illnesses, including syphilis, malignancies, malaria, asthma, chorea, eczema and psoriasis (Foster and George $\mathrm{H}$. Rohe1896). Today, arsenic trioxide $\left(\mathrm{As}_{2} \mathrm{O}_{3}\right)$ is an FDA approved therapy to treat acute promyelocytic leukemia and also shows promising anticancer activity in laboratory models of other human cancers (Yeh 2011, Wu 2010a, Ai 2011, Ahn 2010). Despite being widely known as toxic, human exposure to arsenic remains as one of the most serious environmental health threats worldwide, due to its prevalence in the environment and diverse negative health impacts.

\section{Arsenicals in Relation to Human Health}

Arsenic toxicity can be split into two categories; one resulting from acute high level exposure and the other from chronic low level exposure. Acute high level exposures to arsenic cause multisystem organ toxicities and often death. High level exposures to arsenic are rare when compared to the estimated 100 million humans worldwide exposed chronically to low levels through the environment (IARC 2004). Exposure to arsenic is drastic in certain places of the world where high levels of environmental arsenic overlap highly populated regions such as in Bangladesh where an alarming 1 in 5 deaths may be related to arsenic exposure (Argos 2010, Flanagan 2012, Smith 2000).

Human exposure to environmental arsenic is associated with many distinct toxicities, including cancer, neurotoxicity, cardiovascular disease, developmental abnormalities, and lung disease (Smith 1998, Chen 2007a, Vahidnia 2007, Vahter 2008, 
Grandjean and K. Murata 2007, Smith 2006, Smith 2011). Of note are the characteristic effects of arsenic on the skin. Low level exposure to arsenic for a prolonged period of time leads to a buildup of keratin (hyperkeratosis) and discoloration in the skin cells. Arsenic has also been linked to a variety of vascular disorders such as hypertension, ischemic heart disease, arteriosclerosis and blackfoot disease (Tseng 1977, Chen 1996, Chen 1988, Chen 1995, Chiou 2005). Recent studies suggest that prenatal exposures to arsenic may result in impaired fetal growth, fetal loss, and an increased rate of post-birth infant mortality (Vahter 2008, Rahman 2010). In the case where an infant survives, prenatal exposures may be involved in delayed toxicities such as development of various malignancies later in life (Waalkes 2008, Smith 2012, Steinmaus 2013). There is even accumulating evidence that long term memory and hormonal regulation are altered by exposure to environmental arsenic (Kapaj 2006).

Of all the toxicities associated with long-term arsenic exposure, cancer is the most widely studied and is the cause of substantial arsenic-linked human mortality. Arsenic was first suspected as a carcinogen at the end of the $19^{\text {th }}$ century by Mr. Jonathan Hutchinson when he noted corny skin lesions and internal tumors in patients who had been taking arsenic to treat psoriasis (Hutchinson 1887). Within the past 50 years, many epidemiological studies have convincingly linked human arsenic exposure with various types of cancer. These studies have established a relationship between elevated arsenic exposure and cancers of the lung, urinary-tract and skin in countries such as Taiwan, Japan, Chile, Argentina and Finland (IARC 2004). Studies also suggest that arsenic associated urinary tract tumors are more advanced and have a poorer prognosis than those 
not associated with arsenic (Tan 2008, Chen 2010). Prostate, kidney and liver cancers are also associated with arsenic, but these associations have less supporting data (Straif 2009).

Most of the arsenical related epidemiological data correlates a disease frequency with the levels of arsenic in the subjects' environment (IARC 2004). These ecological correlations cannot indisputably connect a specific arsenical exposure level with cancer since the amount of arsenic ingested by the subjects in these scenarios is unknown. In some studies, measurements of arsenic are made from toenail clippings or urine samples. These measurements offer a more direct connection between arsenic exposure level and cancer risk; however, the concentration and duration of arsenic exposure required to cause cancer remain unknown.

Based on the vast epidemiological data, the International Agency for Research on Cancer (IARC) has classified arsenic and inorganic arsenic compounds as group 1 human carcinogens. Informed by the epidemiological data connecting urinary tract tumors with low level arsenic exposure (Chen 1992), the world health organization has set a guideline advising that arsenic concentrations in drinking water should not exceed $10 \mathrm{ppb}$ or $10 \mathrm{ug} / \mathrm{L}$ (WHO 1993). This 10ppb limit was adopted by the United States Environmental Protection Agency in 2001 as the maximum contaminant level (US Environmental Protection Agency 2001). While regulations to limit human arsenic exposure are improving, it remains debated whether the current arsenic standards provide adequate protection.

\section{Arsenical Mechanisms of Action}


Despite decades of study, a single central mechanism for arsenic's toxic action has not been identified. Instead, research has identified a complex network of mechanisms which appear to contribute to various facets of arsenical toxicity. These multiple mechanisms of arsenical toxicity may be interconnected with each contributing in additive or synergistic fashions, and specific pathways of toxicity may predominate at specific doses or in specific tissues.

While human epidemiological studies are important to progress in toxicology, the fact that study participants live in uncontrolled environments leaves many open ended questions. One issue that arises in such studies is how to accurately determine the subjects' exposure levels to various toxicants. In the case of arsenic, most of the epidemiological studies rely on measurements of arsenic in the environment to predict a subject's exposure, although this may not always reflect their actual exposure. This vagueness surrounding arsenical dosage in humans makes it difficult to tie arsenic to a specific biological effect when there are so many additional factors in a subject's lifestyle and environment that may be contributing. For example, tobacco is a complete carcinogen and its use, like arsenic exposure, is linked to bladder cancer. To complicate things even more, a concrete pharmacokinetic profile for arsenic in humans is still lacking (El-Masri and E. M. Kenyon 2008, Kenyon 2008). In summary, while the epidemiological evidence clearly correlates arsenic exposure with increased disease incidence and progression, it tells us little about the exact role of arsenic in producing these effects. 
Laboratory experiments are critical in determining the role of arsenic in producing toxicity because they allow for control of parameters that affect arsenical toxicity. By isolating the variables that are uncontrollable in epidemiological studies, it may be possible to identify predominant or common pathways of toxicity induced by arsenical exposure. In practice, altering experimental parameters has revealed many distinct facets of arsenical induced toxicity. For example, the effects of arsenic are dose dependent. Rather than amplifying the effects of a low dose, high dose arsenic can produce a unique effect (Gentry 2010). The various arsenical species and metabolites add even more pieces to the puzzle that is arsenic toxicity. Most perplexing are the model specific effects of arsenic. In short, laboratory studies have provided much insight about the role of arsenic in human toxicity although they have not yet clarified a single predominant mechanism.

Through all the studies, several prominent mechanisms have emerged to describe how arsenic exposure leads to toxicity. As reactive and toxic molecules, the primary action of arsenicals is to bind proteins, especially at sulfhydryls. The broad interaction between arsenicals and many diverse cellular proteins is likely the underlying driver of most other mechanisms of arsenical induced toxicity reported in the literature. Another early effect of arsenic exposure is the production of reactive oxygen species. Together, prolonged protein binding by arsenic and oxidative stress may lead to epigenetic remodeling, which has a pivotal role among the mechanisms of arsenic induced carcinogenesis because it can stabilize the aberrant cellular behaviors. Other prominent mechanisms which may also be secondary to protein binding and oxidative stress are 
DNA damage and signaling perturbation. The secondary mechanisms mentioned here are not exclusive and they may be working in concert, sequentially or at different exposure levels. It is clear that secondary to protein binding, no single mechanism will be able to fully describe the toxic effects of arsenic.

\section{Protein Binding}

It has been shown in several systems that certain arsenicals have an affinity for many proteins especially in their ability to bind sulfhydryls (Miller 2002, Ralph 2008). When arsenicals bind to active proteins their function is altered or abolished. This in turn has numerous downstream effects. For example, the DNA methyltransferase enzymes are rich in sulfhydryl groups which might be bound by arsenic, disrupting the enzymes' functions (Reichard and A. Puga 2010). This is one possible way in which arsenical protein binding could directly lead to epigenetic dysfunction. Furthermore, arsenic has been shown to replace specific ions from their protein binding pockets, thus altering the activities of transcription factors and other enzymes which depend on ionic cofactors. For instance, arsenic has been found to replace zinc ions in certain zinc finger DNA binding motifs (Zhou 2011). Overall, protein binding by arsenic provides a general stress on cells, which have to replace damaged proteins that served a variety of functions. If the arsenic burden on a cell is too high, it will not be able to repair all the damage and may initiate apoptosis, autophagy, or another cell-death pathway. The non-specific interaction of arsenicals with cellular proteins is one possible contributor to the tissue and dose specific toxicity of arsenicals since the toxicity will depend on the unique levels and types of proteins present in each particular cell type. 
Reactive Oxygen Species (ROS)

Cellular ROS increase following arsenic exposure, and are known culprits of DNA damage and altered signaling. Human keratinocytes and urothelial cells both showed elevated ROS after exposure to As ${ }^{\mathrm{III}}$ or $\mathrm{MMA}^{\mathrm{III}}$ and this oxidative stress was reversible with enzymatic and non-enzymatic anti-oxidants (Eblin 2006, Shi 2004, Ding 2005, Eblin 2008). Superoxide anion and its secondary radicals cause DNA strand breaks which if not repaired may lead to chromosomal deletions. Although the DNA damage produced by ROS is an attractive mechanism to explain arsenical mediated carcinogenicity, there is evidence that arsenic can induce malignant transformation and DNA hypomethylation independent of DNA damage (Kojima 2009, Tokar 2011b). ROS are also thought to be important factors in the developmental establishment of normal epigenetic profiles (Hitchler and F. E. Domann 2007), which emphasizes their potential role in arsenical induced epigenetic dysfunction.

\section{DNA Damage}

Arsenic exposure is frequently associated with DNA damage on the micro and macro scale. On the micro scale, arsenic exposure is associated with oxidation of bases and single strand breaks (Kessel 2002, Mouron 2006). This type of damage is reparable if a cell has intact DNA repair mechanisms. On a macro scale, arsenic exposure is associated with micronuclei induction and chromosomal aberrations (Paton and A. C. Allison 1972, Beckman 1977). For example, in bladder tumors, there is an increasing trend of chromosomal gains and losses as arsenic exposure increases (Moore 2002). Unlike many other carcinogenic DNA damaging agents, arsenic does not directly interact 
with DNA or produce point mutations (Rossman 1980, Kligerman 2003). Its ability to cause DNA damage might be contingent upon its ability to induce ROS (Kitchin and S. Ahmad 2003, Nesnow 2002).

\section{Epigenetic Remodeling}

A number of observations regarding the effects of long-term arsenic exposure suggest epigenetic remodeling may play an important role in human oncogenesis and perhaps other arsenic-linked chronic diseases. The facts that most arsenicals on their own are unable to cause cancer in standard animal assays (IARC 2004) and that arsenic doesn't appear to cause point mutations (Rossman 1980) suggest a potential importance of epigenetic remodeling in arsenic induced carcinogenicity. Arsenic has also been shown to increase the carcinogenicity of other chemicals which lead to its classification as a co-carcinogen (Rossman 2001), providing further evidence that DNA damage may not be its primary mechanism. Since arsenic is not a complete carcinogen or a strong mutagen at environmentally relevant concentrations (reviewed in (Rossman 2003)), epigenetic remodeling may be a major mechanism of stable phenotypic change in arsenic induced malignant transformation. All this suggests that epigenetic remodeling may play a major role in chronic arsenic induced toxicity and that it warrants in depth discussion with respect to arsenical toxicity.

Long-term arsenic exposure alters chromatin structure via changes to DNA methylation and post-translational histone modifications. Globally, DNA becomes hypomethylated with regions of hypermethylation often localized near $\mathrm{CpG}$ island gene promoters. These arsenic induced epigenetic changes are linked to functional changes in 
gene expression, appear stable, and are maintained even after removal of arsenic exposure.

\section{Models to Study Arsenical Action}

Many different experimental models have been used to study arsenic's mechanisms of toxicity. These models span a range from bacteria and yeast to rodents and primates. Each of these models has distinct strengths and weaknesses with respect to experimenting with arsenical toxicity. Human cell lines are especially useful when studying arsenic toxicity because of their relevance to arsenic induced carcinogenesis in vivo.

Non-mammalian model organisms may provide insights into the general epigenetic mechanisms involved in arsenical induced toxicity. Bacteria and yeast are useful models because of their simplicity and may allow for the identification of fundamental mechanisms involved in arsenical toxicity. These models offer convenient genetic manipulation which has been used to discover mechanisms of arsenic sensitivity and resistance (Paez-Espino 2009, Jo 2009). However, their biological simplicity may limit the applicability of the resulting data to human toxicity. Complex organisms such as fruit flies and fish offer toxicologists multicellular organisms that contain internal organs and have been successfully used to study the effects of arsenic exposure (Bagnyukova 2007, Muniz Ortiz 2011).

Mammals are a traditional choice for toxicological studies because they are closely related to humans. However, the effects of arsenic in various mammalian species are paradoxical which has limited their usefulness in modeling human arsenical toxicity. 
For instance, arsenicals by themselves do not cause cancer in most mammalian species (IARC 2004). This is in contrast to the epidemiological data which strongly associates arsenic exposure with human cancers. It is now known that arsenic consistently produces tumors in mice which are exposed transplacentally, and that the carcinogenic effects of arsenic in rodents are dependent on developmental stage (Waalkes 2003, Tokar 2011a). Species such as guinea pigs, marmosets and chimpanzees are unable to methylate arsenic (Goering 1999, Healy 1997, Vahter 1995, Vahter and E. Marafante 1985) which results in an exposure profile that is dramatically different from our own. The variability of arsenical metabolism between distinct mammalian models and humans may contribute to the inter-species variability to arsenic induced toxicity. Even among humans there is evidence that the extent to which we metabolize arsenic varies and that this variation influences our susceptibility to arsenic toxicity (Yu 2000, Valenzuela 2005, GomezRubio 2010, Schlawicke Engstrom 2009). Despite differences between humans and other mammals with respect to arsenic toxicity, animal models have contributed much to our understanding of arsenical induced toxicity and will continue to be valuable tools to model arsenical toxicity in humans.

Since the effects of arsenic in animal models have been unpredictable, human cell lines also play an important role in determining the mechanisms of arsenical induced toxicity and carcinogenesis. Human cell lines have proven useful because they are relevant to in vivo human toxicity and can originate from the various target tissues of arsenical induced toxicity. For instance, it is known that arsenic exposure is associated with cancers of the skin, lung and bladder. From each of these human tissues there exist 
cell lines which are used to model environmental arsenical exposure in vitro (Pi 2003, Wang 2011, Sens 2004). While in vitro systems still lack the complexity of an entire organism, cell lines provide an experimentally tractable system. For example, to account for the inter-tissue variability of arsenical metabolism, individual metabolites or combinations of them can be used in vitro to mimic the in vivo exposures of various tissues. One complication with using normal cell strains is that they have a limited lifespan once they are removed from their donors, and arsenic has not proven capable of immortalizing finite lifespan cells. As a result, most of the cells which are used for chronic arsenical exposures have been genetically immortalized beforehand in order to extend their lifespan in culture. This is convenient for the sake of chronic toxicity studies, but leaves the cells in a pre-malignant state rather than an entirely normal one. As it turns out, these genetic immortalization events may be prerequisites to arsenical induced malignant transformation. This is supported by the lack of evidence for arsenic alone as a complete carcinogen in normal cells and most animal models. In summary, while immortalized human cell lines are useful models in general, they may be particularly valuable when studying chronic arsenical exposure as they may provide an accurate reflection of the role of arsenic in human tumorigenesis.

\section{Epigenetic Mechanisms and their Roles}

Epigenetics is the study of mechanisms that can produce a stable and heritable phenotypic change without any change to the genetic sequence. Epigenetic mechanisms are responsible for the establishment and maintenance of cellular identity, producing different cell types that share the same genetic sequence (Suzuki and A. Bird 2008, 
Kouzarides 2007, Futscher 2002, Jiang and B. F. Pugh 2009, Ringrose and R. Paro 2007). While both genetic and epigenetic information are heritable, only the epigenetic mechanisms are reversible. These mechanisms include DNA methylation, posttranslational histone modifications, nucleosome remodeling, RNA interference, and nuclear localization. Epigenetic mechanisms are known to play major roles in many normal biological processes such as development, differentiation, $\mathrm{X}$ chromosome inactivation, transcriptional regulation and silencing of endogenous retroviral elements (Jiang and B. F. Pugh 2009, Augui 2011, Minard 2009, Rowe and D. Trono 2011). Since epigenetic marks are reversible, they provide a mechanism of genomic plasticity which allows cells to respond to a changing and potentially harmful environment. Not surprisingly, disruption of normal patterns and levels of DNA methylation and posttranslational histone modifications have been implicated in a variety of complex human diseases (Portela and M. Esteller 2010).

One of the best characterized mechanisms of epigenetic regulation is that of DNA methylation. This DNA modification occurs at the 5-carbon position of cytosines, primarily those which are immediately upstream of a guanine nucleotide. This sequence of nucleotides, a cytosine immediately followed by a guanine in the 5' to 3' direction, is referred to as a $\mathrm{CpG}$ dinucleotide or $\mathrm{CpG}$ site. $\mathrm{CpG}$ dinucleotides are not spread evenly throughout the human genome. Rather, they tend to cluster into short stretches of DNA known as $\mathrm{CpG}$ islands. One definition of a $\mathrm{CpG}$ island is a region of the genome with an observed/expected CpG ratio greater than 0.6, which is 3 times greater than the overall genome, and GC content greater than $50 \%$. These islands occur in approximately $60 \%$ of 
gene promoters and tend to overlap transcriptional start sites, leaving them in a position to regulate gene transcription. In normal cells, $\mathrm{CpG}$ islands contain mostly unmethylated CpGs. In general, methylation of CpGs in a $\mathrm{CpG}$ island is directly linked to long-term transcriptional silencing of its associated gene. In normal embryonic stem cells, most of the $\mathrm{CpG}$ dinucleotides spread throughout the genome are methylated while those $\mathrm{CpG}$ dinucleotides which are clustered into islands remain unmethylated, permitting expression of the corresponding genes (Atkinson and L. Armstrong 2008). As normal stem cells differentiate, the pattern of DNA methylation largely stays the same on a global level but specific regions change in association with their gene expression state, such as pluripotency genes. Thus a tissue specific pattern of DNA methylation develops which permits expression of tissue specific genes and represses expression of stem cell specific or pluripotency genes (Minard 2009).

Another important mechanism of epigenetic regulation is that of post-translational histone modifications. The core histone proteins $(\mathrm{H} 2 \mathrm{~A}, \mathrm{H} 2 \mathrm{~B}, \mathrm{H} 3, \mathrm{H} 4)$ are the targets of numerous covalent modifications such as acetylation, methylation, phosphorylation, sumoylation and ubiquitination with each contributing to the overall chromatin state. Compared to DNA methylation, these histone modifications display greater plasticity and each has a role in regulating gene expression. For example, acetylation of the core histones at various lysine residues is associated with gene expression. Methylation of lysine residues can be permissive or repressive of gene transcription depending on the specific lysine residue. For instance, H3 lysine 9 dimethylation (H3K9me2) is associated with tightly condensed chromatin, DNA methylation and repression of gene expression 
(Wen 2009). Similarly, H3 lysine 27 trimethylation (H3K27me3), which is deposited by a Polycomb Repressive Complex, acts to silence promoters of differentiation specific genes and can function independently of DNA methylation (Ringrose and R. Paro 2007). $\mathrm{H} 3$ lysine 4 trimethylation $(\mathrm{H} 3 \mathrm{~K} 4 \mathrm{me} 3)$ is found at the promoters of actively transcribed genes. Bivalent domains are those promoters which are marked with both the permissive $\mathrm{H} 3 \mathrm{~K} 4 \mathrm{me} 3$ and the repressive $\mathrm{H} 3 \mathrm{~K} 27 \mathrm{me} 3$. Such regions are tightly regulated in stem cells to either maintain pluripotency or induce differentiation of progeny cells (Bernstein 2006).

The combination of DNA methylation with various post-translational histone modifications regulates the structure and activity of our genes, without altering the genes themselves. Together, these epigenetic mechanisms establish a unique epigenetic landscape for each cell type which leaves accessible a specific subset of genes while repressing others which are not used by the particular cell type. In short, the epigenetic landscape of a cell is tightly linked to its phenotypic capabilities. Aberrations to this tightly controlled landscape are a ubiquitous event in human cancer that plays a participative role in the carcinogenic process.

While aberrant epigenetic mechanisms were first widely-studied in cancer, it is likely that they are applicable to many chronic diseases. All cancer cells harbor a dramatically altered epigenetic profile when compared to their normal tissue counterparts. The aberrant epigenome of cancer cells accounts for a significant portion of their malignant phenotype. Since cancer is the disease most often associated with chronic arsenic exposure, the epigenetic effects of arsenic have mostly been studied in the context 
of carcinogenesis. But, as the epigenetic mechanisms behind arsenic induced cancer are unraveled, they should certainly be considered as potential mechanisms in other arsenic associated chronic diseases.

\section{Epigenetic Effects of Arsenicals}

Many studies from different research disciplines now support the hypothesis that epigenetic remodeling plays an important role in arsenical induced toxicity. The human subject and human cell line data which support this hypothesis are summarized in Table 1.1. Tumor and blood samples collected from human subjects living in The United States, Taiwan, China and India have all correlated arsenic exposure with gene specific DNA hypermethylation in the promoters of genes such as DAPK, p16, RASSF1A and PRSS3 (Chanda 2006, Chen 2007b, Marsit 2006, Zhang 2007). Whether or not the DNA methylation status of DNA from blood cells is a useful biomarker of arsenic toxicity remains to be determined (Terry 2011). These human subject studies suggest that environmental arsenic exposure is associated with hypermethylation in promoters of genes with tumor suppressor functions.

To date, there are only a few studies that investigate altered histone modifications in human subjects exposed to arsenic. Cantone et al sampled peripheral blood leukocytes (PBLs) and measured global increases in H3 lysine 9 acetylation (H3K9Ac) and H3 lysine 4 dimethylation (H3K4me2), but it is not known where these changes occur within the genome (Cantone 2011). Similarly, Chernova et al sampled peripheral blood mononuclear cells (PBMCs), but they found a positive correlation between total urinary arsenic and H3K9me2 and a negative correlation with H3K9Ac (Chervona 2012). 
Evaluating histone modifications in samples from human subjects presents many technical challenges. In order to obtain high resolution and meaningful data from such samples requires a large sample size. Since DNA methylation is more stable and more straightforward to probe than histone modifications, it may prove a more robust biomarker of human arsenic exposure. 
Table 1.1 Summary of studies which test the effects of arsenical exposure on epigenetic marks in human subjects and cell lines. Abbreviations used: PBL-peripheral blood leukocytes, PBMC - peripheral blood mononuclear cells, $\uparrow$--increase, $\downarrow$--decrease, $5 \mathrm{mc}$ 5-methylcytosine, As PM-arsenic particulate matter, H3K9Ac-histone H3 lysine 9 acetylation, H3K4me2 - histone H3 lysine 4 dimethylation, H3Ac-Histone H3 acetylation, H4K16Ac-Histone $\mathrm{H} 4$ lysine 16 acetylation, $\mathrm{H}_{3} \mathrm{~S} 10 \mathrm{PO}_{4}$ - Histone $\mathrm{H} 3$ serine 10 phosphorylation, $\mathrm{H}_{2} \mathrm{AXPO}_{4}$ - Histone $\mathrm{H} 2 \mathrm{AX}$ phosphorylation

\begin{tabular}{|c|c|c|c|c|}
\hline Model & Arsenical & Genes & Mark & References \\
\hline \multicolumn{5}{|l|}{ Human Subjects } \\
\hline PBL & $\mathrm{As}^{\mathrm{III}}$ & Global & $\uparrow 5 \mathrm{mc}$ & $\begin{array}{l}\text { (Pilsner 2007, } \\
\text { Majumdar 2010) }\end{array}$ \\
\hline PBL & $\mathrm{As}^{\mathrm{III}}$ & $\begin{array}{l}\text { Global (in skin lesion } \\
\text { patients) }\end{array}$ & $\downarrow 5 \mathrm{mc}$ & (Pilsner 2009) \\
\hline Whole blood & $\mathrm{As}^{\mathrm{III}}$ & p53 \& p16 & $\uparrow 5 \mathrm{mc}$ & (Chanda 2006) \\
\hline Bladder tumors & $\mathrm{As}^{\mathrm{III}}$ & RASSF1A \& PRSS3 & $\uparrow 5 \mathrm{mc}$ & (Marsit 2006) \\
\hline Urothelial carcinomas & $\mathrm{As}^{\mathrm{III}}$ & DAPK & $\uparrow 5 \mathrm{mc}$ & (Chen 2007b) \\
\hline PBL & $\mathrm{As}^{\mathrm{III}}$ & p16 & $\uparrow 5 \mathrm{mc}$ & (Zhang 2007) \\
\hline PBL & As PM & Global & $\begin{array}{l}\uparrow \mathrm{H} 3 \mathrm{~K} 9 \mathrm{Ac} \\
\uparrow \mathrm{H} 3 \mathrm{~K} 4 \mathrm{me} 2\end{array}$ & (Cantone 2011) \\
\hline PBMC & & Global & $\begin{array}{l}\uparrow \mathrm{H} 3 \mathrm{~K} 9 \mathrm{me} 2 \\
\downarrow \mathrm{H} 3 \mathrm{~K} 9 \mathrm{Ac}\end{array}$ & (Chervona 2012) \\
\hline \multicolumn{5}{|l|}{ Human Cells } \\
\hline Urothelial, UROtsa & $\begin{array}{l}\mathrm{As}^{\mathrm{III}} \text { or } \\
\text { MMA }^{\mathrm{III}}\end{array}$ & $\begin{array}{l}\text { DBC1, FAM83A, } \\
\text { ZSCAN12, } \\
\text { C1QTNF6, G0S2, } \\
\text { EREG, KRT7 } \\
\text { Global } \\
\text { WNT5A } \\
\text { WNT5A } \\
\text { WNT5A } \\
\text { WNT5A } \\
\text { WNT5A } \\
\text { Global }\end{array}$ & $\begin{array}{l}\downarrow 5 \mathrm{mc} \\
\downarrow 5 \mathrm{mc} \\
\uparrow \mathrm{H} 3 \mathrm{Ac} \\
\uparrow \mathrm{H} 3 \mathrm{~K} 4 \mathrm{me} 2 \\
\downarrow \mathrm{H} 3 \mathrm{~K} 27 \mathrm{me} 3 \\
\downarrow \mathrm{H} 3 \mathrm{~K} 9 \mathrm{me} 2 \\
\downarrow \mathrm{H} 4 \mathrm{~K} 16 \mathrm{Ac}\end{array}$ & $\begin{array}{l}\text { (Jensen 2008, Wnek } \\
\text { 2010) } \\
\text { (Jensen 2009a) } \\
\text { (Jensen 2009b) }\end{array}$ \\
\hline $\begin{array}{l}\text { Prostate Epithelial, } \\
\text { RWPE1 }\end{array}$ & $\mathrm{As}^{\mathrm{III}}$ & Global & $\downarrow 5 \mathrm{mc}$ & $\begin{array}{l}\text { (Coppin 2008, } \\
\text { Benbrahim-Tallaa } \\
\text { 2005a) }\end{array}$ \\
\hline Keratinocytes, $\mathrm{HaCaT}$ & $\mathrm{As}^{\mathrm{III}}$ & Global & $\downarrow 5 \mathrm{mc}$ & (Reichard 2007) \\
\hline Urothelial, SV-HUC & $\mathrm{As}^{\mathrm{III}}$ & DAPK & $\uparrow 5 \mathrm{mc}$ & (Chai 2007) \\
\hline Myeloma, U266 & $\mathrm{As}^{\mathrm{III}}$ & p16 & $\uparrow 5 \mathrm{mc}$ & $\begin{array}{l}\text { (Fu and J. Z. Shen } \\
\text { 2005) }\end{array}$ \\
\hline Lung adenocarcinoma, & $\mathrm{As}^{\mathrm{III}}$ & p53 & $\uparrow 5 \mathrm{mc}$ & (Mass and L. Wang \\
\hline
\end{tabular}




\begin{tabular}{|c|c|c|c|c|}
\hline A549 & $\mathrm{As}^{\mathrm{III}}$ & Global & $\begin{array}{l}\uparrow \mathrm{H} 3 \mathrm{~K} 9 \mathrm{me} 2 \\
\downarrow \mathrm{H} 3 \mathrm{~K} 27 \mathrm{me} 3 \\
\uparrow \mathrm{H} 3 \mathrm{~K} 4 \mathrm{me} 3\end{array}$ & $\begin{array}{l}\text { 1997) } \\
\text { (Zhou 2008) } \\
\text { (Zhou 2008, Zhou } \\
\text { 2009) }\end{array}$ \\
\hline APL & $\mathrm{As}_{2} \mathrm{O}_{3}$ & CASPASE-10 & $\begin{array}{l}\uparrow \mathrm{H} 3 \mathrm{~K} 14 \mathrm{Ac} \\
\uparrow \mathrm{H} 3 \mathrm{~S}_{10 \mathrm{PO}_{4}}\end{array}$ & (Li 2002) \\
\hline Fibroblasts & $\mathrm{As}^{\mathrm{III}}$ & c-jun, c-fos & $\begin{array}{l}\uparrow \mathrm{H} 3 \mathrm{~K} 14 \mathrm{Ac} \\
\uparrow \mathrm{H} 3 \mathrm{~S}_{10 \mathrm{PO}_{4}}\end{array}$ & (Li 2003) \\
\hline $\begin{array}{l}\text { Hepatocarcinoma, } \\
\text { HepG2 }\end{array}$ & $\mathrm{As}^{\mathrm{III}}$ & Global & $\uparrow \mathrm{H} 3 \mathrm{~K} 9 \mathrm{Ac}$ & (Ramirez 2008) \\
\hline Lung cancer, H157 & $\mathrm{As}_{2} \mathrm{O}_{3}$ & Global & $\uparrow \mathrm{H} 2 \mathrm{AXPO}_{4}$ & (Park 2008) \\
\hline Melanoma, RPMI7951 & $\mathrm{As}^{\mathrm{III}}$ & Global & $\uparrow \mathrm{H} 2 \mathrm{AXPO}_{4}$ & (Zykova 2006) \\
\hline
\end{tabular}

Table 1.1 - Continued 
Given that human arsenic exposure has a clear association with urinary tract tumors, there is a strong rationale to study the epigenetic effects of arsenic as they relate to carcinogenesis in cells derived from the urinary tract. The bladder, ureters, and pelvis of the kidneys are all lined with a specialized layer of epithelial cells called the urothelium, which is the site of carcinogenesis in many people exposed to environmental arsenic. Tumor development in the urothelium is a multistep process brought about by a series of heritable genetic and epigenetic events. An early and critical step in this process is immortalization (Stampfer and P. Yaswen 2003). Work done by Stampfer et al in a normal human mammary epithelial (HMEC) model elucidates several pathways to immortalization with critical genetic alterations (Stampfer and P. Yaswen 2003, Stampfer and J. C. Bartley 1985, Garbe 2007, Brenner 1998). Novak et al discovered that regardless of the pathway, hundreds of DNA methylation changes precede immortalization of HMEC (Novak 2009). A similar magnitude of DNA methylation change has been observed in immortalized urothelial cells relative to their normal tissue counterparts independent of arsenic exposure (discussed in Chapter 2) implying that these changes may be linked to immortalization of all epithelial cell types. As research into the area of arsenic induced epigenetic dysfunction progresses, it is important to distinguish the aberrant epigenetic events linked to immortalization from those associated with arsenic exposure and malignant transformation.

The UROtsa cell line is an example of an immortalized urothelial cell line that was derived from the ureter of a 12-year old girl, and is used to study the effects of chronic arsenic exposure. These cells were immortalized by the addition of the SV40 
large $\mathrm{T}$ antigen which blocks the function of $\mathrm{p} 53$ and $\mathrm{Rb}$, two critical tumor suppressor genes which are commonly altered in human cancers. UROtsa cells have overcome the proliferation barriers which function in normal urothelial cells, but they do not form tumors when transplanted into immunocompromised mice. UROtsa cells exposed to long term non-toxic concentrations of $\mathrm{As}^{\mathrm{III}}$ or $\mathrm{MMA}^{\mathrm{III}}$ gradually acquire new phenotypes characteristic of malignant cells (Sens 2004, Bredfeldt 2006), including increased proliferation, colony formation on soft agar and tumorigenicity in immunocompromised mice. These new behaviors persist even after removal of the arsenical, indicating that arsenicals are able to induce malignant transformation of immortalized UROtsa cells. Similar arsenic induced malignant transformations have been performed in other immortalized human cell lines derived from target tissues of arsenical toxicity such as prostate and lung epithelia (Achanzar 2002a, Chang 2010). Together, these immortalized cells and their arsenic transformed counterparts provide relevant human models of arsenical exposure in which to study the effects of arsenic on epigenetic mechanisms.

Probing the DNA methylation profile of the arsenical transformed UROtsa cells revealed that the phenotypic changes were linked to both global and gene specific changes in DNA methylation. With respect to malignant transformation, Jensen et al measured hypermethylation of $\sim 3 \%$ and hypomethylation of $\sim 1 \%$ of an approximate 10,000 element microarray. The hypermethylation events occurred mostly within gene promoters, whereas the hypomethylation events were more prevalent in repetitive elements spread throughout the genome (Jensen 2009a). Furthermore, these DNA methylation changes coincided with the acquisition of malignant phenotypes, and both 
the epigenetic and phenotypic changes were retained in cells that were removed from arsenic exposure for 6 months (Jensen 2009a). Several potential tumor suppressor genes were found to be hypermethylated such as DBCCR1 (Deleted in Bladder Cancer Chromosome Region candidate 1) and G0S2. DBCCR1 seems especially relevant since it is a gene that is commonly deleted or silenced by hypermethylation in human bladder cancers (Nishiyama 2001). Overall, the DNA methylation pattern in arsenic transformed UROtsa is similar to that which is seen in practically all cancers; global hypomethylation of the genome with hypermethylation events localized to $\mathrm{CpG}$ islands of gene promoters (Jensen 2009a, Jensen 2008).

Other cell lines besides UROtsa show a similar change in their DNA methylation profile on both a global level and in gene promoters after chronic arsenic exposure, as have some animal models. The immortalized human prostate epithelial cell line RWPE-1 was shown to undergo genomic hypomethylation after chronic exposure to As ${ }^{\mathrm{III}}$ (Benbrahim-Tallaa 2005a, Coppin 2008). Likewise, several in vitro and in vivo animal studies show global DNA hypomethylation after chronic arsenic exposure (Chen 2004, Xie 2004, Waalkes 2004, Uthus and C. Davis 2005, Okoji 2002, Bagnyukova 2007, Sciandrello 2004, Zhao 1997). Together, these studies indicate that chronic arsenic exposure can lead to hypomethylation of DNA on a global level. As for changes in gene promoters, an SV40 immortalized urothelial cell line distinct from UROtsa showed gene specific hypermethylation (Chai 2007) and several animal models also show hyper and hypomethylation of specific gene promoters after arsenic exposure (Waalkes 2004, Chen 2001, Cui 2006, Okoji 2002, Takahashi 2002) . Taken together, these studies all confirm 
that chronic arsenic exposure can lead to aberrant patterns of DNA methylation on global and gene specific levels.

Numerous studies have characterized gene expression changes associated with acute arsenic exposure (reviewed in (Gentry 2010)). Based on what is known about the importance of covalent histone modifications in the dynamic regulation of gene expression, there is strong rationale for many of these arsenic associated gene expression changes being linked to changes in post-translational histone modifications. At low arsenical doses, one might expect to see alterations of histone modifications that permit expression of genes which allow the cells to cope with the stress. At high arsenic doses one would predict chromatin changes that induce up regulation of proapoptotic genes or other genes associated with cell death. The histone modification changes associated with these acute low and high level arsenic exposures are likely part of the normal cellular response to arsenic, and may or may not be important factors in arsenic associated chronic disease. With chronic arsenic exposures, it is assumed that a subset of all the histone modifications altered will be associated with a phenotypic switch from normal to chronically diseased cells. So far, little has been done to separate the normal histone modification changes from those which are functionally linked to a stable alteration in cellular phenotype of arsenic exposed cells.

The effects of low dose, chronic arsenic exposure on covalent histone modifications have been measured in the UROtsa model (Jensen 2008). Jensen et al found in UROtsa cells malignantly transformed with long-term low level exposure to either $\mathrm{MMA}^{\mathrm{III}}$ or $\mathrm{As}^{\mathrm{III}}$ an altered histone acetylation state at many gene promoters with an 
overlap shared by both the MMA ${ }^{\mathrm{III}}$ and As ${ }^{\mathrm{III}}$ transformed cells. This overlap indicates that the histone acetylation changes are not occurring at random genes. Indeed, some of the genes targeted for epigenetic modification in vitro are also found altered in vivo. Such is the case with the gene DBCCR1, which was hypoacetylated after As ${ }^{\mathrm{III}}$ and MMA $^{\mathrm{III}}$ exposure in UROtsa and is deleted or epigenetically silenced in human bladder cancers (Nishiyama 2001). Four of the genes whose promoters were hypoacetylated after either MMA ${ }^{\mathrm{III}}$ or As ${ }^{\mathrm{III}}$ transformation were picked as candidates to measure gene expression. The expression of these genes was significantly reduced in the arsenical transformed cells, indicating that the $\mathrm{H} 3$ hypoacetylation changes are linked to functional gene expression changes (Jensen 2008) and are not merely silent modifications.

Additionally, Jensen et al discovered that WNT5A was hyperacetylated and overexpressed after the chronic arsenical exposure. In addition to significant increases in H3 acetylation, As ${ }^{\mathrm{III}}$ exposed UROtsa cells had significant increases of H3K4me2 and decreases of $\mathrm{H} 3 \mathrm{~K} 27 \mathrm{me} 3$ and $\mathrm{H} 3 \mathrm{~K} 9 \mathrm{me} 2$ in the WNT5A promoter region. Similarly, MMA $^{\mathrm{III}}$ exposed UROtsa showed increased $\mathrm{H} 3$ acetylation and $\mathrm{H} 3 \mathrm{~K} 4 \mathrm{me} 2$ with decreased H3K27me3 in the WNT5A promoter (Jensen 2009b). This histone mediated epigenetic activation and the malignant phenotype were stable even after the removal of the arsenic. WNT5A is known to be up regulated in bladder cancers, and knocking down its expression in arsenical exposed cells inhibited anchorage-independent growth. This study demonstrates that chronic arsenic exposure can produce stable covalent histone modifications which alter the expression of genes relevant to malignant transformation. Lastly, Jo et al demonstrated that the global H4K16 acetylation levels are decreased in 
UROtsa cells after acute $\mathrm{As}^{\mathrm{III}}$ or MMA ${ }^{\mathrm{III}}$ treatment, and that the ability of the cells to acetylate H4K16 helped them to resist arsenic toxicity (Jo 2009). All these studies confirm that arsenical exposure will alter histone modifications at gene specific genomic locations and globally in UROtsa cells.

In other models, arsenic exposure has also altered histone acetylation and methylation. Human fibroblasts exposed to arsenic showed increased histone acetylation and expression of two proto-oncogenes, c-fos and c-jun (Li 2003). Human liver cancer cells had an increase in histone H3 acetylation after arsenite exposure (Ramirez 2008). Human lung adenocarcinoma cells showed an increase of H3K4me3 and H3K9me2 after arsenic exposure, two marks that have opposite effects on transcription. These cells also had a decrease of H3K27me3, a repressive histone modification (Zhou 2009, Zhou 2008). Considering all the data, it is clear that arsenic exposure induces changes to the many covalent histone modifications of a cell, but so far there is not enough data to formulate whether an arsenic specific pattern of histone modifications exists or which of the modifications promote chronic disease.

\section{Research Questions of the Present Studies and their Rationale}

It is widely accepted that malignancies resulting from chronic exposure to environmental arsenicals will harbor genome wide epigenetic aberrations suggesting that arsenic exposure disrupts the epigenome as one of its mechanisms to produce cancer. Several lines of evidence have been described which lend support for this hypothesis. To restate them: most arsenicals on their own are unable to cause cancer in standard animal assays and arsenic doesn't appear to cause point mutations. Finally, epidemiological 
studies have shown that children exposed to arsenic are at a greater risk for cancer and other chronic diseases later in life even though they were only exposed as children, suggesting that the changes caused by arsenic in the children were stable (Smith 2012, Steinmaus 2013). All this supports the hypothesis that epigenetic remodeling is a predominant factor in arsenic induced toxicity and that it warrants further study.

The precise role that arsenic plays in producing epigenetic aberrations is unknown. Most in vitro studies of arsenical induced epigenetic dysfunction have been performed in a single model system or in a targeted fashion. This makes it difficult to know which epigenetic changes were linked to arsenic exposure since each model begins with its own unique epigenomic profile. In addition, only genome wide epigenetic analyses can determine the full scope of arsenic induced epigenetic dysfunction. In order to better understand the nature of arsenic induced epigenetic dysfunction we have expanded on previous studies by using microarray techniques with more comprehensive coverage of the human genome and comparing multiple in vitro models of toxicantinduced malignant transformation. Expanding both the technique used to measure the DNA methylation profile and the number of distinct samples in the set enables the present studies to address the following research questions.

- Do arsenical-transformed cell lines harbor an arsenic-specific epigenetic signature compared to malignancies not associated with arsenical exposure?

- Does arsenic exposure affect the epigenome in a unique manner compared to other toxicants (i.e. cadmium, MNU)? 
- What is the genomic distribution of aberrant DNA methylation in arsenicaltransformed cell lines?

- Which arsenical-induced aberrant DNA methylation events are linked to stable gene expression changes? 


\section{CHAPTER 2: AGGLOMERATES OF ABERRANT DNA METHYLATION ARE ASSOCIATED WITH TOXICANT-INDUCED MALIGNANT TRANSORMATION}

Text and Figures in this section are derived from: Severson PL, Tokar EJ, Vrba L, Waalkes MP, Futscher BW. 2012. Epigenetics 7(11):1238-48.

\section{Introduction}

Experiments have shown that long-term arsenic or cadmium exposure in vitro induces malignant transformation of several immortal cell lines, but the underlying mechanisms driving these toxicant-induced malignant transformations are multi-faceted and remain elusive (Sens 2004, Achanzar 2002a, Wang 2011, Achanzar 2001).

Epigenetic dysfunction is emerging as an important aspect of both arsenic and cadmium associated chronic diseases, especially cancer (Ren 2011, Hou 2012, Bollati and A. Baccarelli 2010).

In addition to genetic alterations, epigenetic changes are a driving force in cancer (Sharma 2010). Earlier studies have shown that the aberrant DNA methylation profiles of distinct cancer models correlate with the degrees of their aberrant phenotypes (Jensen 2009a, Novak 2009). In other words, as the phenotype of a cell progresses towards malignancy, its epigenetic patterning also becomes increasingly distinct from that of its normal tissue counterpart. For example, during the immortalization of human mammary epithelial cells few to hundreds of differentially methylated regions (DMRs) arose concurrently and were correlated with the escape from distinct proliferation barriers 
(Novak 2009). During the later stages of tumorigenic progression, DMRs were observed to accumulate more gradually while correlating with advanced malignant phenotypes (Jensen 2009a, Novak 2009).

In addition to targeting individual genes, cancer associated epigenetic dysfunction is known to occur across large chromosomal regions which can encompass many genes. In normal cells, epigenetic mechanisms such as DNA methylation, histone H3 lysine-27 trimethylation (H3K27me3) and histone $\mathrm{H} 3$ lysine-9 trimethylation (H3K9me3) play important roles in silencing individual genes as well as large chromosomal regions or even entire chromosomes such as the inactive $\mathrm{X}$ of females (reviewed in (Trojer and D. Reinberg 2007)). Likewise, genomic scale analyses of cancers have shown that epigenetic dysfunction targets individual genes and larger chromosomal regions containing many genes (Frigola 2006, Stransky 2006, Rauch 2007, Novak 2008, Novak 2006). These large scale aberrations of repressive epigenetic modifications have collectively been called long-range epigenetic silencing (LRES) (Clark 2007). Groups of DMRs that are enriched within defined chromosomal regions have been called agglomerative epigenetic aberrations and these agglomerative DNA methylation events can contribute to LRES (Novak 2008). LRES events are unique epigenetic lesions that have been observed in various types of tumors, but they have not been linked to any specific carcinogen exposure (Frigola 2006, Novak 2008, Javierre 2011, Dallosso 2009, Dallosso 2012). The fact that they are observed in tumors supports their clinical relevancy and suggests that carcinogen exposure could lead to their induction. 
The present study examines two in vitro models, RWPE-1 and UROtsa, which have been used successfully to study epigenetic dysfunction associated with arsenical or cadmium-induced malignant transformation. These immortalized cell lines are nontumorigenic and were derived from the prostate and ureter respectively, which are target sites for cadmium and arsenic-induced cancers (Petzoldt 1995, Bello 1997, SOMMERS and R. G. MCMANUS 1953, Chen 1992, Benbrahim-Tallaa and M. P. Waalkes 2008, Straif 2009). Long-term, independent exposures of these cell lines to arsenite (As ${ }^{\mathrm{III}}$ ), monomethylarsonous acid $\left(\mathrm{MMA}^{\mathrm{III}}\right)$ and cadmium $\left(\mathrm{Cd}^{\mathrm{II}}\right)$ induced hyperproliferation, conferred anchorage independent growth and tumorigenicity (Sens 2004, Achanzar 2002a, Achanzar 2001, Wnek 2010, Benbrahim-Tallaa 2005b). The resulting tumorigenic cell lines provide valuable models to study the epigenetic component of arsenical or cadmium-induced malignant transformation in relevant target tissues. Previous studies have shown that the arsenical or cadmium-transformed variants of RWPE-1 and UROtsa harbor stable aberrations to their DNA methylation profiles, including global hypomethylation and gene promoter hypermethylation (Jensen 2009a, Jensen 2009b, Jensen 2008, Benbrahim-Tallaa 2005a).

This study extends on prior studies by using higher resolution DNA methylation analyses, allowing us to gain further insights into aberrant DNA methylation patterns induced by long-term toxicant exposure. In this study we compare aberrant DNA methylation in two relevant models of arsenical or cadmium-induced malignant transformation which enables us to distinguish the effects which are model-specific, toxicant-specific or generally found in cancers. The results lend further support to the 
hypothesis that epigenetic dysfunction plays an important role in toxicant-induced malignant transformation by showing that clinically relevant, agglomerative aberrations of DNA methylation occur during arsenical and cadmium-induced malignant transformation.

\section{Materials and Methods}

\section{Cell culture and sample acquisition}

UROtsa, URO-ASSC, and URO-CDSC cells were contributed by Drs. Donald and Mary Ann Sens. The UROtsa cell line was created from the urothelial cells of a 12year-old female donor that were immortalized using a temperature sensitive SV40 largeT antigen construct (Petzoldt 1995). URO-ASSC cells were created through continuous exposure of UROtsa to $1 \mu \mathrm{M}$ arsenite for one year (Sens 2004). Similar to the arseniteinduced transformation, URO-CDSC cells were created by continuous exposure of UROtsa to $1 \mu \mathrm{M}$ cadmium for one year (Sens 2004). URO-MSC cell lines were contributed by Dr. Jay Gandolfi and were created through continuous exposure of UROtsa cells to $50 \mathrm{nM} \mathrm{MMA}^{\mathrm{III}}$ as previously described (Wnek 2010). Each of the UROtsa cell lines was cultured as previously described (Jensen 2008). The blackfoot transitional cell carcinoma lines (BFTC-905 and BFTC-909) were acquired from the German Collection of Microorganisms and Cell Cultures (Tzeng 1996, Cheng 1995). BFTC-905 and BFTC-909 were derived from urothelial carcinomas of individuals who lived in blackfoot endemic regions of Taiwan where high level exposure to arsenic is common. BFTC-905 and BFTC-909 were cultured at $37^{\circ} \mathrm{C}$ with $5 \% \mathrm{CO}_{2}$ in DMEM with 
$10 \% \mathrm{FBS}$ and $1 \% \mathrm{vol} / \mathrm{vol}$ penicillin-streptomycin solution with media changes three times per week and sub-culturing before reaching confluence. The non-tumorigenic RWPE-1 cell line was derived from prostate epithelial cells that were infected with human papillomavirus 18 to induce immortalization (Bello 1997). RWPE-1 cells were cultured in K-SFM with $50 \mu \mathrm{g} / \mathrm{mL}$ BPE, $5 \mathrm{ng} / \mathrm{mL}$ EGF, and 1\% vol/vol antibioticantimycotic solution. RWPE-1 cells were continuously exposed to $5 \mu \mathrm{M}$ sodium arsenite for up to 35 weeks and are referred to as CAsE-PE cells after undergoing arseniteinduced malignant transformation (Achanzar 2002a, Benbrahim-Tallaa 2005a). RWPE-1 cells were also malignantly transformed by exposure to $10 \mu \mathrm{M}$ cadmium for 10 weeks and the resulting line is called cadmium-transformed prostate epithelial cells (CTPE). WPE1-NB26 is a malignant cell line that was created previously by exposure of RWPE-1 cells to $100 \mu \mathrm{g} / \mathrm{mL} \mathrm{N}$-methyl-N-nitrosourea (MNU) for 4 cycles of $1 \mathrm{hr} /$ passage, after which cells were selected by xenografting twice through nude mice and growth on soft agar (Webber 2001). WPE1-NB26 cells were cultured as previously described (Webber 2001). Normal human prostate epithelial cells (PrEC) cryopreserved at passage two were acquired from ATCC and cultured in $\operatorname{PrEBM}^{\mathrm{TM}}$ with added BulletKit ${ }^{\mathrm{TM}}$ (Lonza). Normal female human urothelial cells (HUC) were acquired from ScienCell ${ }^{\mathrm{TM}}$ Research Laboratories and cultured in Urothelial Cell Medium (ScienCell Research Laboratories). The prostate cancer cell lines PC3, LNCaP and DU145 were cultured in Iscove's Modified Dulbecco's Medium (IMDM), RMPI-1640 and IMDM respectively with 10\% FBS and $1 \%$ vol/vol antibiotic-antimycotic solution at $37^{\circ} \mathrm{C}$ and $5 \% \mathrm{CO}_{2}$. Short tandem repeat (STR) profiling was performed on each cell line either to validate its origin or 
confirm a unique DNA profile in the case where none has been published. DNA samples from six human urothelial carcinoma tumor biopsies were purchased from Origene Technologies.

Nucleic acid isolation

Genomic DNA was isolated using the DNeasy Blood and Tissue Kit according to manufacturer's protocol (Qiagen). The quantity of each sample was assessed using absorbance at $260 \mathrm{~nm}$ on the NanoDrop 1000 Spectrophotometer.

\section{MeDIP coupled to microarray (MeDIP-on-Chip)}

MeDIPs were performed as previously described (Weber 2005). Briefly, $5 \mu \mathrm{g}$ of RNase-treated genomic DNA were sonicated and analyzed on a 1\% agarose gel. Ten percent of the sonicated sample was preserved as input, while the remaining sonicated DNA was denatured at $100^{\circ} \mathrm{C}$ before overnight incubation with an antibody to $5 \mathrm{mc}$. DNA-antibody conjugates were immunoprecipitated by incubation with protein A Sepharose GL-4B beads, washed, eluted and purified. MeDIP and input samples were amplified, labeled, hybridized and washed as previously described (Vrba 2011). The following modifications were made for samples hybridized to the G4489A Human Promoter ChIP-on-Chip Microarray Set 244K designs 014706 and 014707 (Agilent Technologies, Santa Clara, CA). Two micrograms of each amplified MeDIP and input were labeled for each slide of the 2-slide set. After labeling, the MeDIPs and inputs were combined and then divided into two equal volumes before drying down to $187.5 \mu \mathrm{L}$ each. To each was added $12.5 \mu \mathrm{L}$ human cot-1 DNA (1 mg/mL, Invitrogen Cat. No. 15279- 
011), $50 \mu \mathrm{L} 10 \mathrm{X}$ Agilent blocking agent and $250 \mu \mathrm{L} 2 \mathrm{X}$ Agilent hybridization buffer before incubation at $95^{\circ} \mathrm{C}, 37^{\circ} \mathrm{C}$ and hybridization. Independent MeDIPs and inputs from identical or similar samples to those used on the Agilent G4489A Human Promoter ChIP-on-Chip Microarray Set 244K were amplified, labeled and hybridized to a custom Agilent tiling microarray, design 024305, as previously described (Vrba 2011). This microarray covers 718 miRNA hairpin regions and includes extensive tiled coverage of all the HOX and protocadherin gene family clusters. Microarray data were deposited in NCBI's Gene Expression Omnibus (GEO) (http:/www.ncbi.nlm.nih.gov/geo/) under accession number GSE38930.

\section{MeDIP-on-Chip data analysis}

Microarray data were imported to R (R_Development_Core_Team 2010) and normalized as previously described (Vrba 2011). M values ( $\log 2$ ratios of immunoprecipitated and input channel) were used for further analysis as a measure of enrichment of a region centered on individual probes. The multidimensional scaling plot was generated using pairwise distances between samples that were derived from all $\mathrm{M}$ values and the function cmdscale in R. For calculation of DMRs, M values were analyzed in a sliding window of $1200 \mathrm{bp}$, with a step of one probe. DMRs were defined as regions of at least three consecutive probes less than $600 \mathrm{bp}$ apart where the mean difference of ratios was at least 1.5 fold. For this particular study, a highly stringent pvalue cut off of 0.001 was selected as a way to suppress background noise in the system. 
The false discovery rate (FDR) was $\leq 1 \%$ and was determined by analysis of permutated data.

Detection of agglomerates and regions enriched with stem cell domains.

The Agilent G4489A promoter microarray coverage was binned and annotated to individual genes. Each annotated bin was considered positive if it overlapped the domain of interest (DMR, hESC H3K27me3 or hESC H3K9me3 domain). Data were analyzed in windows of 49 consecutive bins with a step of one bin using the hypergeometric test for the difference of the expected and observed number of positive bins in each window. pvalues were adjusted for multiple testing.

MassARRAY EpiTYPER ${ }^{T M}$ DNA methylation analysis

EpiTYPER DNA methylation analysis was performed as previously described (Sequenom) (Novak 2009, Novak 2008). Briefly, sodium bisulfite treated DNA was prepared using the DNA Methylation Gold Kit (Zymo Research) following the manufacturer's recommendations. Region specific primers were designed using EpiDesigner (http://www.epidesigner.com/start3.html). The EpiTYPER primer sequences are provided in Appendix A and they include the T7 RNA polymerase binding sequence as well as the 10 nucleotide linker. PCR reactions were performed in 384-well plates, followed by shrimp alkaline phosphatase treatment using the reagents supplied with the Sequenom kit. Products were then incubated with T7 RNA polymerase and RNase A at $37^{\circ} \mathrm{C}$ for 3 hours followed by desalting. Desalted products were analyzed using the Sequenom MALDI-TOF mass spectroscopy apparatus. 


\section{Results}

\section{Malignant transformation produces hundreds of DMRs in distinct models}

This study was an effort to better understand the DNA methylation events of arsenic and cadmium-induced malignant transformation. Using MeDIP-on-Chip we analyzed the DNA methylation changes that occur during arsenic or cadmium-induced malignant transformation of immortal cell lines. Table 2.1 lists the cell lines that were analyzed by MeDIP-on-Chip in this study with descriptions of their treatments and phenotypes. The schematic in Figure 2.1A shows the lineage of the in vitro models of toxicant target tissues used in this study which represent normal, immortal and malignant phenotypes. HUC and PrEC are phenotypically normal cells with finite lifespans. Although these cell strains have distinct genotypes, their DNA methylation profiles can be used to represent that of the normal epithelial tissues of origin of UROtsa and RWPE1 due to the stability and low variability of DNA methylation in normal tissues (Hansen 2011, Behn-Krappa 1991). We used this collection of normal, immortal and malignant models to help us put toxicant-induced aberrant DNA methylation into context with the methylation changes that occur generally in prostate and urothelial carcinogenesis. 


\begin{tabular}{|c|c|c|c|c|c|c|}
\hline Sample & Exposure & Conc. & Duration & $\begin{array}{l}\text { Culture Post- } \\
\text { exposure }\end{array}$ & Tumorigenic & Reference \\
\hline $\operatorname{HUC}(\mathrm{N}=2)$ & None & NA & NA & NA & ND & \\
\hline Urotsa $(\mathrm{N}=3)$ & None & NA & NA & NA & No & $\begin{array}{l}\text { (Petzoldt 1995, } \\
\text { Rossi 2001) }\end{array}$ \\
\hline $\begin{array}{l}\text { URO- } \\
\text { MSC12+24(-) }\end{array}$ & MMA $^{\text {III }}$ & $50 \mathrm{nM}$ & 12 weeks & 24 weeks & Yes & (Wnek 2010) \\
\hline URO-MSC52 & MMA $^{\text {III }}$ & $50 \mathrm{nM}$ & 52 weeks & Yes & Yes & $\begin{array}{l}\text { (Bredfeldt } \\
\text { 2006) }\end{array}$ \\
\hline URO-ASSC & $\mathrm{As}^{\mathrm{III}}$ & $1 \mu \mathrm{M}$ & 52 weeks & Yes & Yes & (Sens 2004) \\
\hline URO-CDSC & $\mathrm{Cd}^{\mathrm{II}}$ & $1 \mu \mathrm{M}$ & 52 weeks & Yes & Yes & (Sens 2004) \\
\hline BFTC-905 & $\mathrm{As}^{\mathrm{III}}$ & NA & NA & Yes & Yes & (Tzeng 1996) \\
\hline BFTC-909 & $\mathrm{As}^{\mathrm{III}}$ & NA & NA & Yes & Yes & (Tzeng 1996) \\
\hline $\begin{array}{l}\text { Bladder Tumor } \\
(\mathrm{N}=6)\end{array}$ & NA & NA & NA & NA & Yes & \\
\hline
\end{tabular}

\begin{tabular}{|l|l|l|l|l|l|l|}
\hline PrEC (N=2) & None & NA & NA & NA & ND & \\
\hline RWPE-1 (N=2) & None & NA & NA & NA & No & (Bello 1997) \\
\hline CAsE-PE (N=2) & As & $5 \mu \mathrm{M}$ & 33 weeks & None & Yes & $\begin{array}{l}\text { (Achanzar } \\
\text { 2002a, } \\
\text { Benbrahim- } \\
\text { Tallaa 2005a) }\end{array}$ \\
\hline CTPE & Cd & $10 \mu \mathrm{M}$ & 10 weeks & None & Yes & $\begin{array}{l}\text { (Achanzar } \\
2001, \\
\text { Achanzar } \\
\text { 2002b) }\end{array}$ \\
\hline WPE1-NB26 & MNU & $\begin{array}{l}100 \\
\mu \mathrm{g} / \mathrm{mL}\end{array}$ & $\begin{array}{l}4 \text { cycles } \\
\text { of 1 hr }\end{array}$ & Yes & Yes & (Webber 2001) \\
\hline LNCaP & None & NA & NA & NA & Yes & $\begin{array}{l}\text { (Horoszewicz } \\
\text { 1983) }\end{array}$ \\
\hline PC3 & None & NA & NA & NA & Yes & (Kaighn 1979) \\
\hline DU145 & None & NA & NA & NA & Yes & (Stone 1978) \\
\hline
\end{tabular}

Table 2.1 Cell lines and samples analyzed by MeDIP-on-Chip. 
Figure 2.1. (A) Schematic showing the origins of the toxicant-transformed cell lines. The dashed arrows indicate that the finite-lifespan and immortal cells have distinct genotypes whereas the malignant cell lines are direct descendants of their corresponding immortal parent. The immortal RWPE-1 cell line was created from a primary culture of PrEC that was immortalized by the addition of HPV18. RWPE-1 cultures were chronically exposed to arsenite or cadmium to create the malignant cell lines CAsE-PE and CTPE. WPE1-NB26 cell were created by $100 \mu \mathrm{g} / \mathrm{mL}$ MNU treatment. The immortal UROtsa cell line was created from a primary culture of HUC by the addition of an SV40 large-T antigen construct. UROtsa cells were malignantly transformed via longterm exposures to arsenite, $\mathrm{MMA}^{\mathrm{III}}$ and cadmium giving rise to URO-ASSC, URO-MSC and URO-CDSC respectively. (B) Multidimensional scaling of pairwise distances derived from the DNA methylation level of gene promoters of all samples shows the relative similarity of the overall DNA methylation profiles of all the samples. The distances between samples in the MDS plot represent the degree of difference between the samples' methylation profiles. The six bladder tumor biopsies are labeled as CD450, CD409, CD293, CD196, CD095 and CD428. Arsenical or cadmium-induced malignant transformation of RWPE-1 alters the DNA methylation profile so that it more closely resembles the cancer cell lines and tumor biopsies. 
A

$\underline{\text { Finite }}$

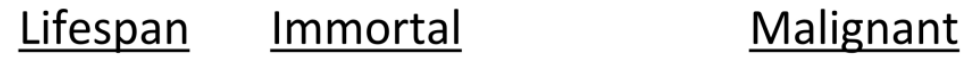

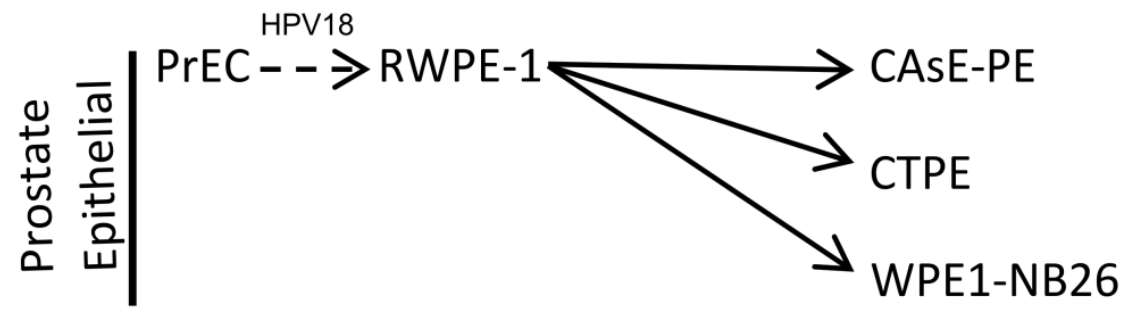

SV40

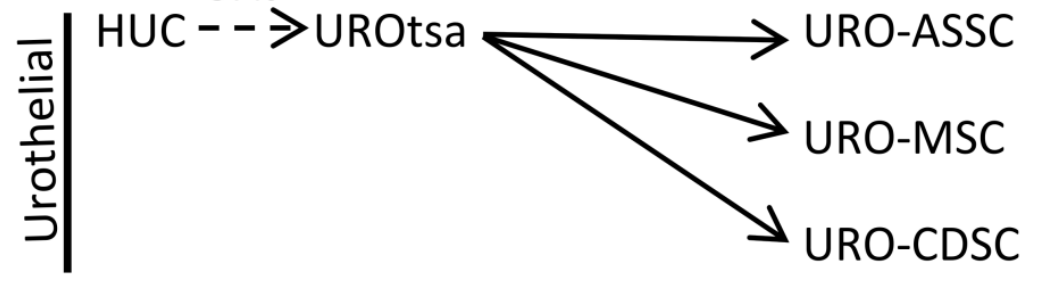

B

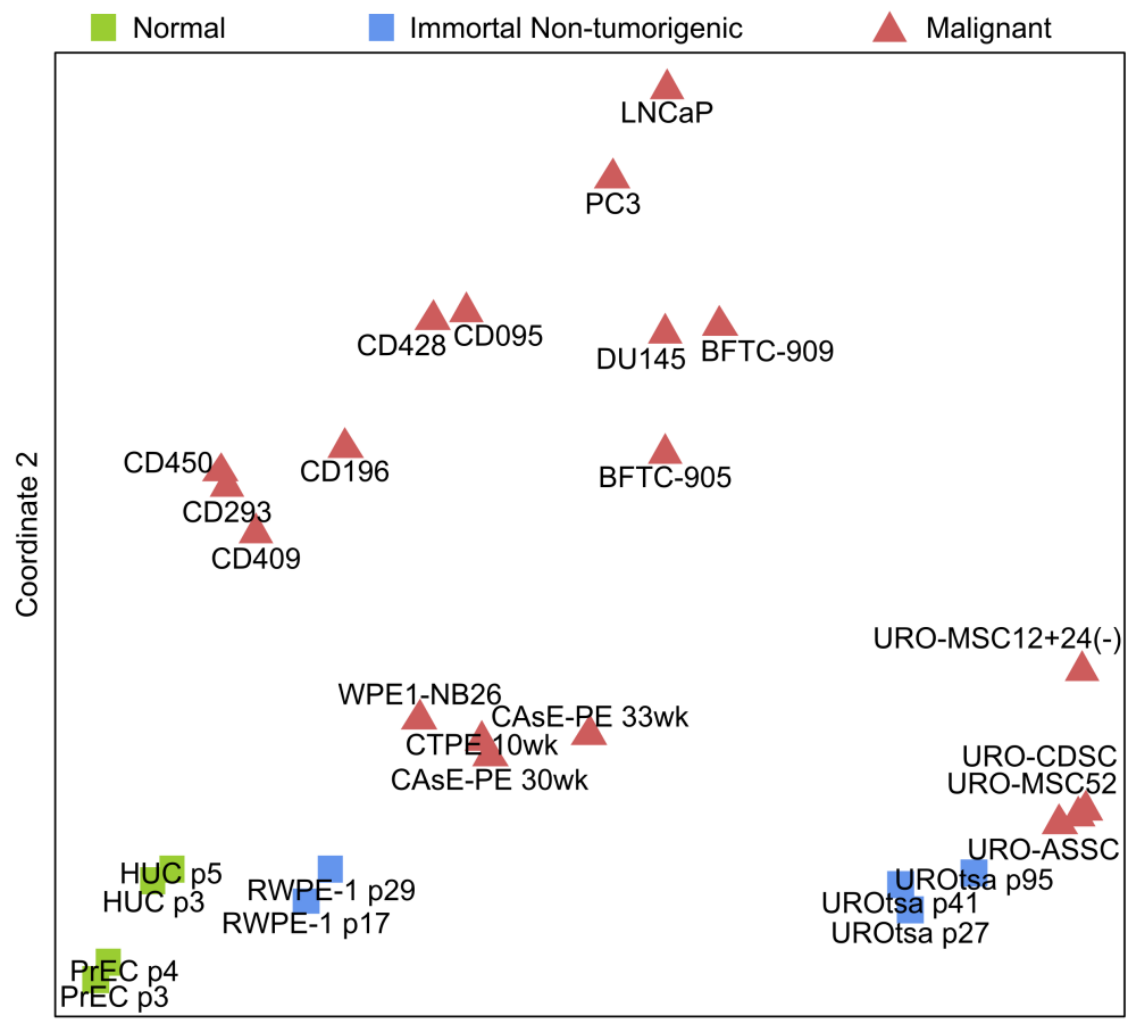

Coordinate 1 
To understand the context of the collective DNA methylation change associated with arsenical or cadmium-induced malignant transformation, we acquired a genome wide DNA methylation profile for each of the cell lines and bladder tumors using MeDIPs coupled to 470,000 probe tiling human promoter microarrays that query 17,000 human gene promoters. We then used multidimensional scaling (MDS) to summarize the data from individual microarray probes and thus graphically represent the variability in the DNA methylation profiles between all the samples (Figure 2.1B). The finite-lifespan cells, HUC and PrEC, are in close proximity to one another after MDS, which indicates that they have similar DNA methylation profiles. MDS also shows that the immortalized RWPE-1 and UROtsa cell lines do not cluster with the finite-lifespan cells, indicating that immortalization had a pronounced effect on the DNA methylation profiles of these cell lines, which is consistent with earlier studies that describe aberrant DNA methylation associated with immortalization (Novak 2009, Huschtscha 1998). Of the two immortalized models, RWPE-1 has a methylation profile more similar to that of the finite-lifespan cells. In summary, the MDS shows that the normal cells have similar methylation profiles while the distinct immortalized cell lines have variable degrees of aberrant DNA methylation which may be related to their pathways of immortalization.

Our analysis includes five cancer cell lines which collectively represent the aberrant DNA methylation events that occur in carcinogenesis. PC3, LNCaP and DU145 were each derived from metastatic prostate cancers and as such their methylation profiles reflect metastatic prostate cancer. The BFTC cell lines were derived from urothelial carcinomas of individuals who lived in blackfoot disease endemic regions, which are 
regions specifically linked to high levels of environmental arsenic (Tzeng 1996). The prostate cancer cell lines and BFTC cell lines have the same tissue origins as RWPE-1 and UROtsa, and thus represent tissue matched models of the end stages of prostate and urothelial carcinogenesis. These five cancer cell lines are closer to one another than to the immortal or finite-lifespan cells in the MDS plot, which suggests that a portion of their DNA methylation profiles is common between them, but different from the other stages (e.g. finite-lifespan, immortal) (Figure 2.1B). This is confirmed in Figure 2.2 which shows that the BFTC cell lines and the prostate cancer cell lines have a substantial overlap of differentially methylated probes compared to their respective finite-lifespan cells and $30 \%$ of these probes are not differentially methylated in immortalized cells compared to normal cells (Appendix A).

In order to assure that the differences between the finite-lifespan cells and the cancer cell lines are relevant to clinical cancers, we included six human bladder tumor biopsies in our analysis. After MDS, the six tumors occupy a common region of the plot. This distribution of the tumor biopsies indicates that their DNA methylation profiles vary from one another while maintaining some similarity relative to the other sample types. Overall, the tumor biopsies are nearer to the cancer cell lines than to the finite lifespan cells which suggests that there may be a common set of aberrant DNA methylation events shared by both the clinical samples and cancer cell line models that correlates with their malignant phenotypes. Venn diagrams comparing aberrantly methylated probes between groups show that $26 \%$ of the differentially methylated probes in the tumor biopsy group 
are also differentially methylated in BFTC and prostate cancer cell lines, and $98 \%$ of these probes are hypermethylated (Figure 2.2). 
Figure 2.2 Venn Diagrams showing the numbers of significant probes compared to respective parent or normal that are shared between the different groups of malignant samples.

(A) Hypermethylated probes commonly overlap between groups which indicates that there are common targets of hypermethylation in the malignant samples.

(B) There are fewer hypomethylated probes overall and they overlap less frequently which indicates that hypomethylation has fewer common targets between the malignant sample types.
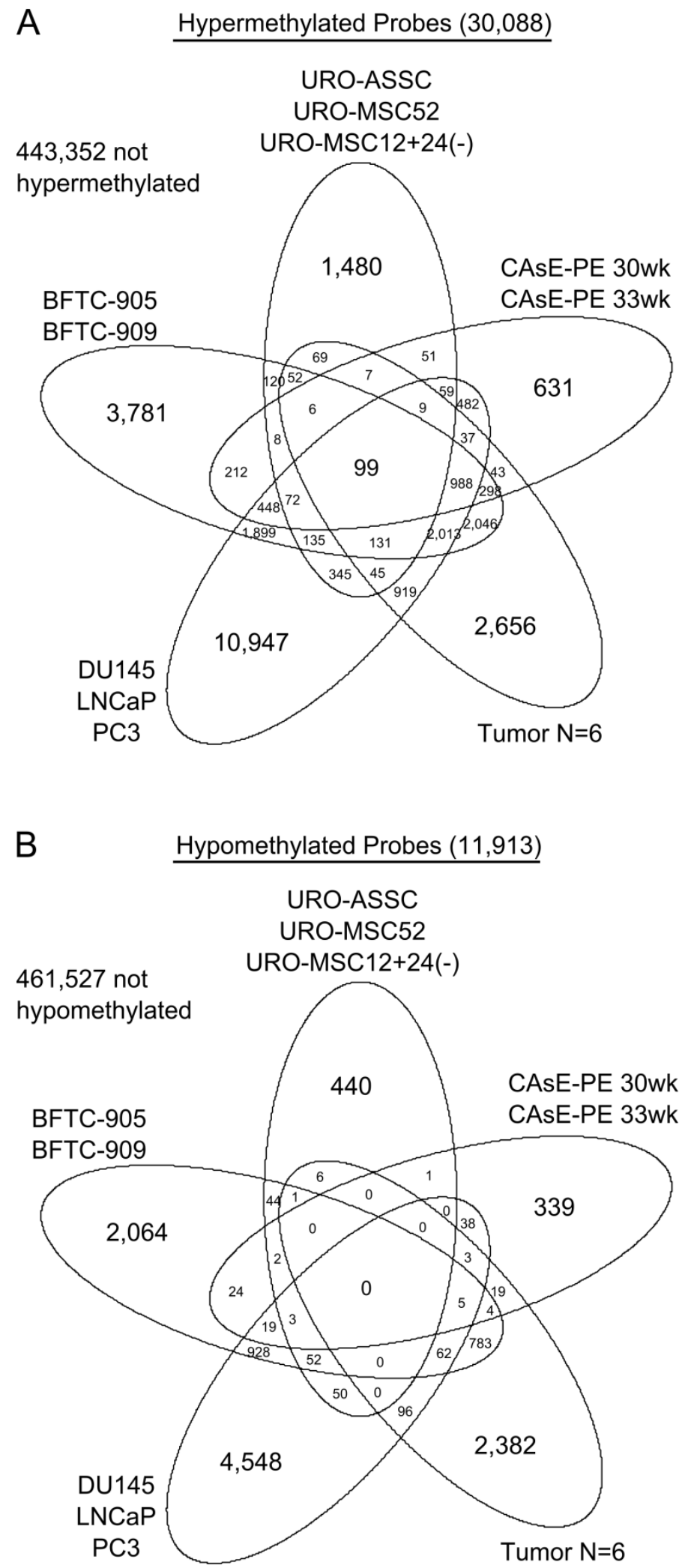
A comparison of the DNA methylation profiles of the virally-immortalized, nontumorigenic cell lines RWPE-1 and UROtsa with their toxicant-transformed counterparts affords an estimate of the degree of aberrant DNA methylation induced by each toxicant. The MDS shows that in every case, transformation by toxicant exposure affected the DNA methylation profile in a similar way for each cell type. Each of the toxicanttransformed cell lines shifts in a similar direction relative to their untreated counterparts (Figure 2.1B) which suggests that each has an analogous methylation change in a comparable portion of the probes. The DNA methylation changes that occur with toxicant-induced malignant transformation of RWPE-1 cells result in DNA methylation profiles that are more like cancer cell lines and tumor biopsies than before toxicantinduced transformation (Figure 2.1B). The increasing similarity between DNA methylation profiles of toxicant-transformed RWPE-1 cells and those of cancer cell lines and tumor biopsies is driven mostly by hypermethylation since there are more hypermethylated probes and they overlap more often than hypomethylated probes (Figure 2.2). Taken together, the MDS and Venn diagrams show that toxicants may induce aberrant DNA methylation events that are common in cancer. In summary, an important interval of epigenetic change can be attributed to toxicant-induced transformation, and this interval correlates with the acquisition of a malignant phenotype.

To more finely resolve the epigenetic changes induced by toxicants and those associated with malignant transformation we identified specific DMRs between grouped samples. Compared to their parent cells, we found a total of 503 and 409 hyper DMRs in the CAsE-PE cells and arsenical-transformed UROtsa cells respectively (Figure 2.3). 
Hypo DMRs were fewer, numbering 72 in CAsE-PE and 98 in the arsenical-transformed UROtsa lines. We also analyzed one cadmium-transformed variant of each immortal cell line as well as the WPE1-NB26 cells which showed that the number of cadmium or MNU-induced DMRs is comparable to those induced by arsenic. In summary, toxicantinduced malignant transformation causes hundreds of DMRs in distinct target tissues. 


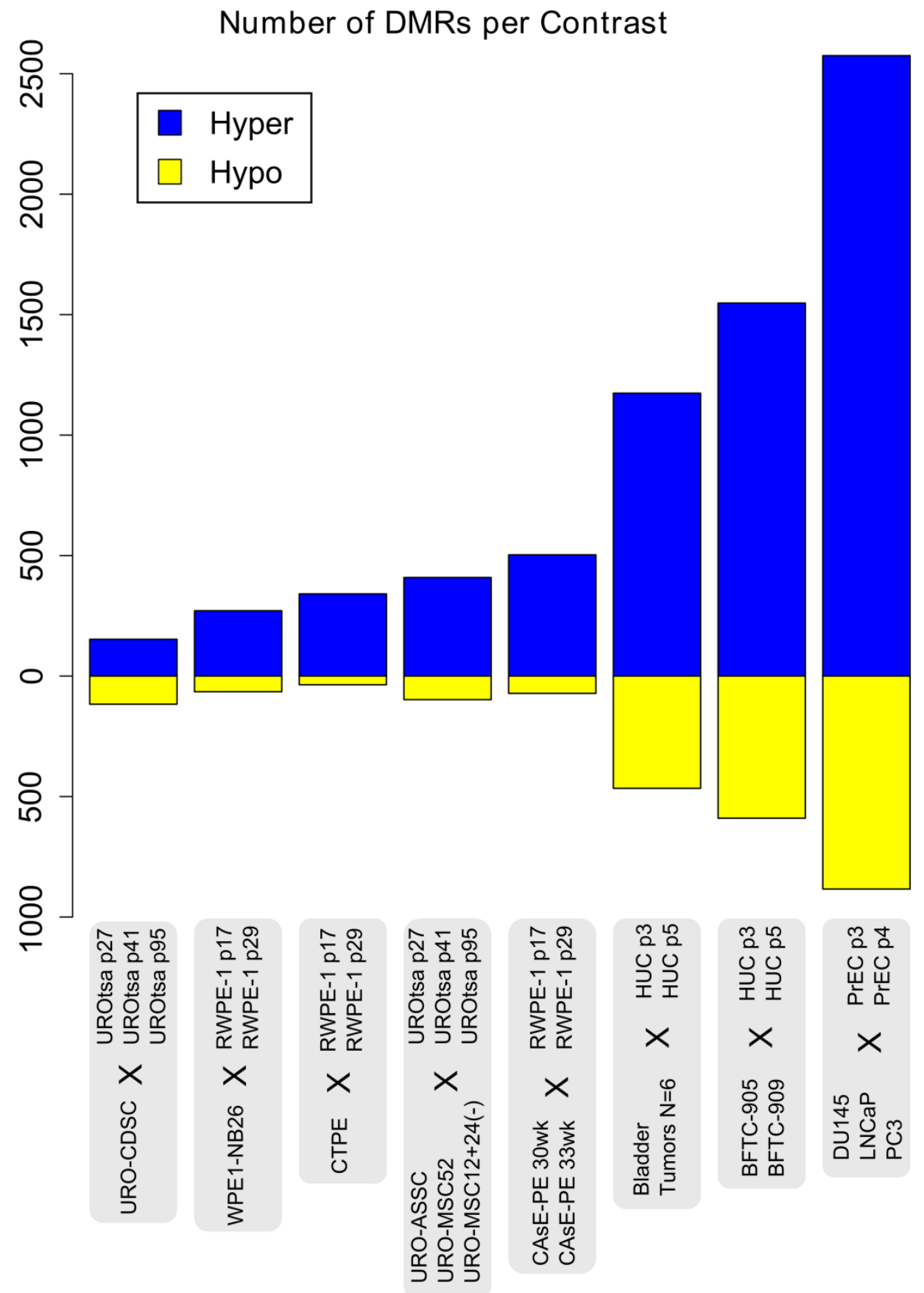

Figure 2.3 DMRs were calculated between the groups of samples shown. The blue and yellow bars show the number of hyper and hypo DMRs generated by the corresponding contrast. 
Agglomerates of aberrant DNA methylation in toxicant-transformed models

We next set out to locate extended regions of the genome that are enriched for DNA hypermethylation events after arsenical transformation of the RWPE-1 cells. This model was chosen to lead the study because the RWPE- 1 cells had a relatively normal DNA methylation profile before exposure. In order to find agglomerative regions of aberrant DNA methylation we systematically scanned the MeDIP-on-Chip data by searching for genomic windows that contained more DMRs than expected by chance. Figure 2.4 shows in red the genomic locations where there is a significant enrichment of DMRs in the CAsE-PE cells. We found six genomic regions with significant enrichment of hyper DMRs in the CAsE-PE cells. These six genomic regions were further cropped to contain only runs of four or more DMRs with less than $200 \mathrm{~kb}$ between adjacent DMRs which left only three aberrant methylation events that meet these criteria (Table 2.2). These three agglomerative events target groups of consecutive genes in the protocadherin, HOXC and HOXD gene family clusters. The methylation status determined by MeDIPon-Chip was confirmed for several of the DMRs within agglomerative regions using the MassARRAY EpiTYPER assay (Figure 2.5, Appendix A). The presence of these agglomerative events in the CAsE-PE cells indicates that arsenic-induced aberrant DNA methylation can target large chromosomal regions in addition to individual genes during malignant transformation. 


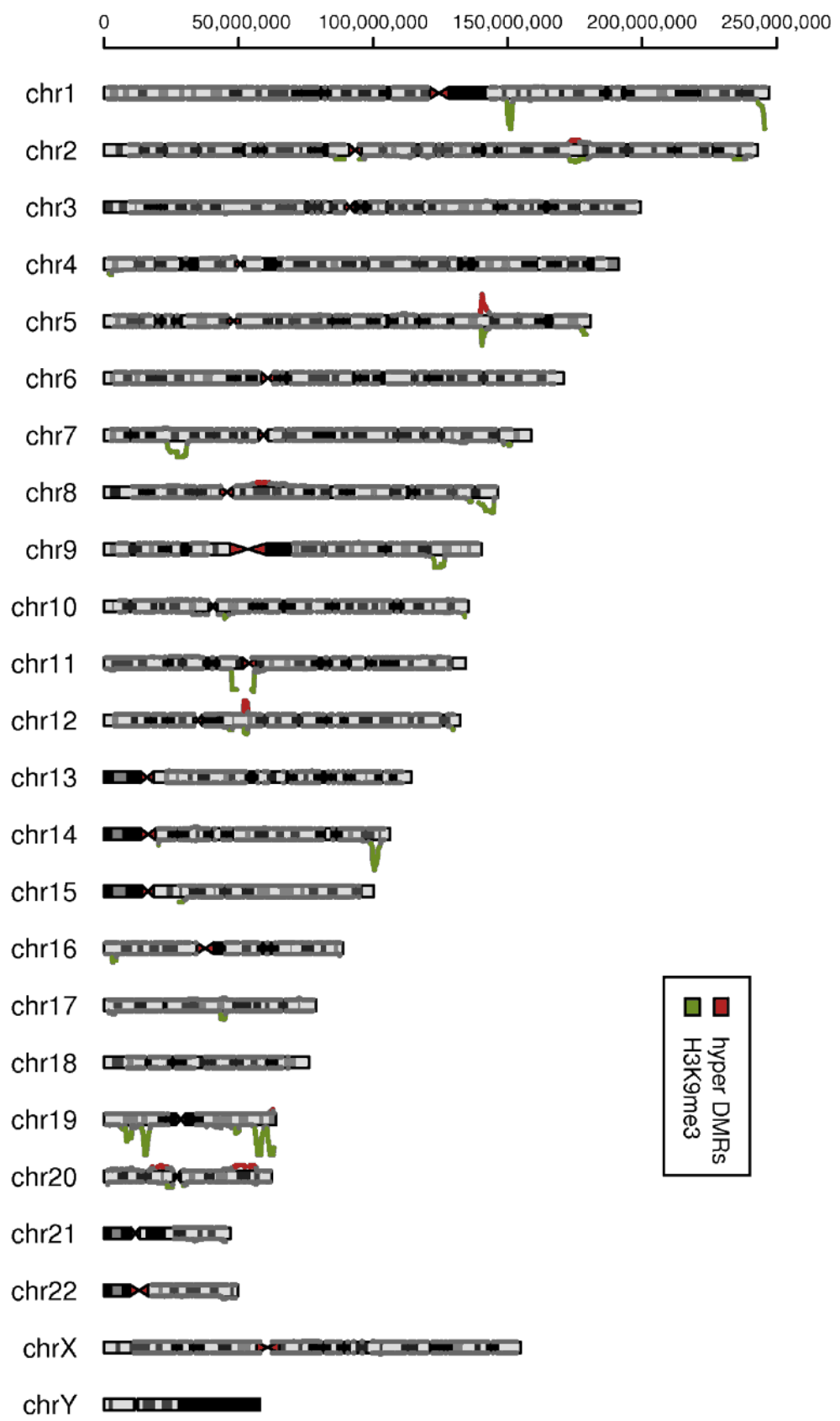

Figure 2.4 Hyper DMRs from CAsE-PE cells were analyzed for agglomerates. The negative $\log _{10}$ of the $\mathrm{p}$-value calculated for each window was plotted as a distance from the respective chromosomal locations. The same calculation was applied to hESC $\mathrm{H} 3 \mathrm{~K} 9 \mathrm{me} 3$ domains to find regions of enrichment within the Agilent promoter ChIP-onChip microarray coverage. Points were plotted in red above or green below the corresponding chromosomal location when the enrichment of DMRs or H3K9me3 domains within the window was statistically significant (adjusted $\mathrm{p} \leq 0.05$ ). 
Each of the three genomic regions with agglomerative hyper DMRs in CAsE-PE cells also shows aberrant hypermethylation in the BFTC cell lines, bladder tumor samples and prostate cancer cell lines relative to HUC or PrEC (Table 2.2). These regions are also hypermethylated after cadmium or MNU-induced transformations of RWPE-1 (Table 2.2, CTPE \& WPE1-NB26). The commonality of hypermethylation in these regions suggests that they are not targets unique to arsenic-transformed cells, but are hypermethylated generally in prostate and urothelial cancers. The fact that some of the agglomerative DMRs are also observed in the bladder tumor biopsies, prostate cancer cell lines, blackfoot cell lines, CTPE and WPE1-NB26 cells suggests that they are clinically relevant, bona fide epigenetic lesions that can be induced by exposure to multiple distinct toxicants (Table 2.3).

The greatest enrichment of DNA hypermethylation in CAsE-PE cells occurred at the PCDH gene family cluster on chromosome 5 and at the HOXC gene family cluster on chromosome 12 (Figure 2.4). The HOXC and PCDH gene family clusters are decisive examples of agglomerative, aberrant DNA methylation. The PCDH cluster has previously been identified in breast cancer as a target of agglomerative DNA hypermethylation and in Wilms' and colorectal tumors as a target of long-range epigenetic silencing (Novak 2008, Dallosso 2009, Dallosso 2012). The HOX clusters are also known targets of LRES (Novak 2008, Novak 2006), and specifically HOXC hypermethylation occurs in astrocytomas (Wu 2010b). 


\begin{tabular}{|c|c|c|c|c|c|c|}
\hline Chr & From (bp) & To (bp) & $\begin{array}{l}\text { Size } \\
(\mathrm{kbp})\end{array}$ & $\begin{array}{l}\text { \# of } \\
\text { DMRs }\end{array}$ & $\begin{array}{l}\text { Genes with } \\
\text { DMRs }\end{array}$ & $\begin{array}{l}\text { Other groups or samples with } \\
\text { hypermethylation }\end{array}$ \\
\hline $\operatorname{chr} 2$ & 176678716 & 176760984 & 82 & 5 & $\begin{array}{l}\text { HOXD11 } \\
\text { HOXD10 } \\
\text { HOXD3 } \\
\text { HOXD1 }\end{array}$ & $\begin{array}{l}\text { (LNCaP \& PC3 \& DU145), } \\
\text { CTPE, (Bladder Tumors), } \\
\text { (URO-ASSC \& URO- } \\
\text { MSC12+24(-) \& URO- } \\
\text { MSC52), URO-CDSC, } \\
\text { (BFTC 905 \& BFTC909), } \\
\text { WPE1-NB26 }\end{array}$ \\
\hline $\operatorname{chr} 5$ & 139907571 & 140844320 & 937 & 18 & $\begin{array}{l}\text { EIF4EBP3 } \\
\text { CD14 } \\
\text { PCDHA3 } \\
\text { PCDHAC2 } \\
\text { PCDHB6 } \\
\text { PCDHB7 } \\
\text { PCDHB16 } \\
\text { PCDHGA2 } \\
\text { PCDHGA3 } \\
\text { PCDHGB4 } \\
\text { PCDHGA8 } \\
\text { PCDHGB5 } \\
\text { PCDHGA10 } \\
\text { PCDHGB7 } \\
\text { PCDHGA11 } \\
\text { PCDHGA12 } \\
\text { PCDHGC4 }\end{array}$ & $\begin{array}{l}\text { (LNCaP \& PC3 \& DU145), } \\
\text { CTPE, (Bladder Tumors), } \\
\text { (BFTC 905 \& BFTC909), } \\
\text { WPE1-NB26 }\end{array}$ \\
\hline $\operatorname{chr} 12$ & 52616802 & 52732432 & 116 & 15 & $\begin{array}{l}\text { HOXC13 } \\
\text { HOXC12 } \\
\text { HOXC11 } \\
\text { HOXC10 } \\
\text { hsa-mir- } \\
\text { 196a2 } \\
\text { HOXC9 } \\
\text { HOXC8 } \\
\text { HOXC6 } \\
\text { HOXC5 } \\
\text { HOXC4 }\end{array}$ & $\begin{array}{l}\text { (LNCaP \& PC3 \& DU145), } \\
\text { CTPE, (Bladder Tumors), } \\
\text { (URO-ASSC \& URO- } \\
\text { MSC12+24(-) \& URO- } \\
\text { MSC52), URO-CDSC, } \\
\text { (BFTC 905 \& BFTC909), } \\
\text { WPE1-NB26 }\end{array}$ \\
\hline
\end{tabular}

Table 2.2 Genomic regions of arsenic-induced agglomerative DNA hypermethylation in CAsE-PE cells $(\mathrm{N}=2)$ found with the Agilent promoter ChIP-on-Chip microarray.

Consecutive genomic windows with $\mathrm{p} \leq 0.05$ (Figure 2.4) were trimmed to include only the regions that contain runs of 4 or more DMRs with less than $200 \mathrm{~kb}$ between adjacent DMRs. This filter was based on randomized CAsE-PE hyper DMR data, which showed that the expected number of runs with four or more DMRs and $200 \mathrm{~kb}$ or less between them is zero. In the non-randomized CAsE-PE data there are three runs which meet these criteria and occur within significant windows of hyper DMR enrichment. Other samples with hyper DMRs in these regions are shown in the final column. Samples underlined and in parenthesis were analyzed as groups. 


\begin{tabular}{|l|l|l|}
\hline Samples & Comparator & $\begin{array}{l}\text { Hypermethylated Gene Clusters (Potential } \\
\text { Agglomerative DMRs) }\end{array}$ \\
\hline CTPE & RWPE-1 (N=2) & HOXD, PCDH, HOXC \\
\hline $\begin{array}{l}\text { Bladder Tumor Biopsies } \\
\text { N=6 })\end{array}$ & HUC (N=2) & PCDH, HOXA \\
\hline PC3, LNCaP, DU145 & PrEC (N=2) & HOXC \\
\hline BFTC-909, BFTC-905 & HUC (N=2) & PCDH, HOXA, HOXC \\
\hline $\begin{array}{l}\text { WPE1-NB26 } \\
\text { MSC52, URO- } \\
\text { MSC12+24(-) }\end{array}$ & RWPE-1 (N=2) & PCDH, HOXC \\
\hline \begin{tabular}{l} 
UROtsa (N=3) \\
\hline
\end{tabular} & HUC (N=2) & PCDH, HOXA \\
\hline
\end{tabular}

Table 2.3 Hyper DMRs were calculated comparing the samples with their corresponding parental or normal cell type. Then, the genome was divided into intervals and a p-value was calculated for each genomic interval based on its level of enrichment with hyper DMRs. The gene family clusters that were significantly enriched with hyper DMRs are listed in the table (adjusted $\mathrm{p} \leq 0.05$ ). 
To better characterize the degree of aberrant methylation within the PCDH, HOXC and HOXD gene family clusters we hybridized independent MeDIPs of our samples to an additional Agilent tiling microarray of custom design. This array has extensive tiled coverage of all the $\mathrm{HOX}$ and $\mathrm{PCDH}$ gene family clusters giving more complete data with respect to the changing methylation pattern in these regions. On this custom array we found that in the CAsE-PE cells, the protocadherin G subfamily cluster (PCDHG) harbors 18 DMRs which collectively span $16 \mathrm{~kb}$ (Figure 2.5). In the HOXC region there are $23 \mathrm{DMRs}$ which collectively span $28.4 \mathrm{~kb}$ of the $151 \mathrm{~kb}$ total array coverage in this region (Appendix A). Within these regions, there is at least one DMR for nearly every gene promoter and these DMRs associate with the $\mathrm{CpG}$ islands of the promoters. The HOXD region contains only five DMRs (Appendix A). 


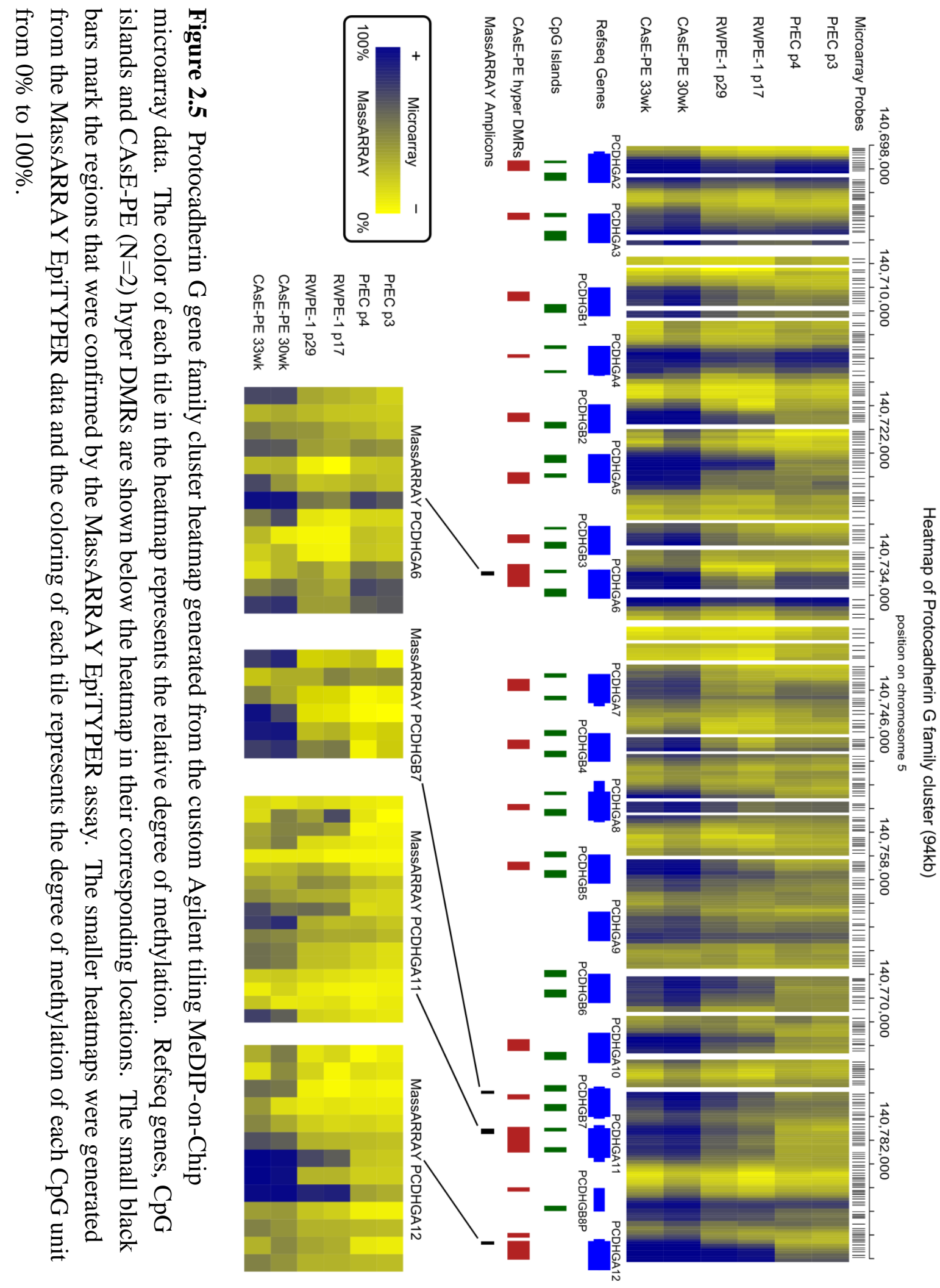


Association of agglomerative DMRs with hESC histone modification domains

In order to better understand the potential mechanisms of arsenic-induced epigenetic dysfunction, we compared the DMRs found in CAsE-PE cells with known domains of histone modifications in human embryonic stem cells. hESC H3K27me3 and hESC H3K9me3 domains were determined previously (Hawkins 2010). H3K27me3 is a transcriptionally repressive mark deposited by the polycomb group proteins and genes that are polycomb targets in stem cells are often targets of aberrant DNA methylation in tumors (Ohm 2007, Schlesinger 2007). H3K9me3 is also a repressive mark and an important component of heterochromatin which has been shown to work in concert with DNA methylation in part by directing its spreading (Epsztejn-Litman 2008, Lehnertz 2003, Fuks 2003). Comparing the locations of DMRs to hESC H3K27me3 and hESC H3K9me3 domains may help determine if aberrant DNA methylation is linked to either of these histone modifications.

To assess the spatial relationships between the arsenical-induced hypermethylation and the stem cell histone modification domains we calculated the number of hypermethylated microarray probes from CAsE-PE cells that occur within hESC H3K27me3 or hESC H3K9me3 domains. Figure 2.6 shows that 76 and 18 percent of the hypermethylated probes in CAsE-PE cells overlap hESC H3K27me3 and hESC H3K9me3 domains respectively. These overlaps are highly significant based on the expected overlaps of 27 and 4 percent for hESC H3K27me3 and hESC H3K9me3 domains respectively. These results suggest that hESC H3K27me3 and hESC H3K9me3 
domains are susceptible to aberrant DNA methylation during malignant transformation of CAsE-PE cells. 

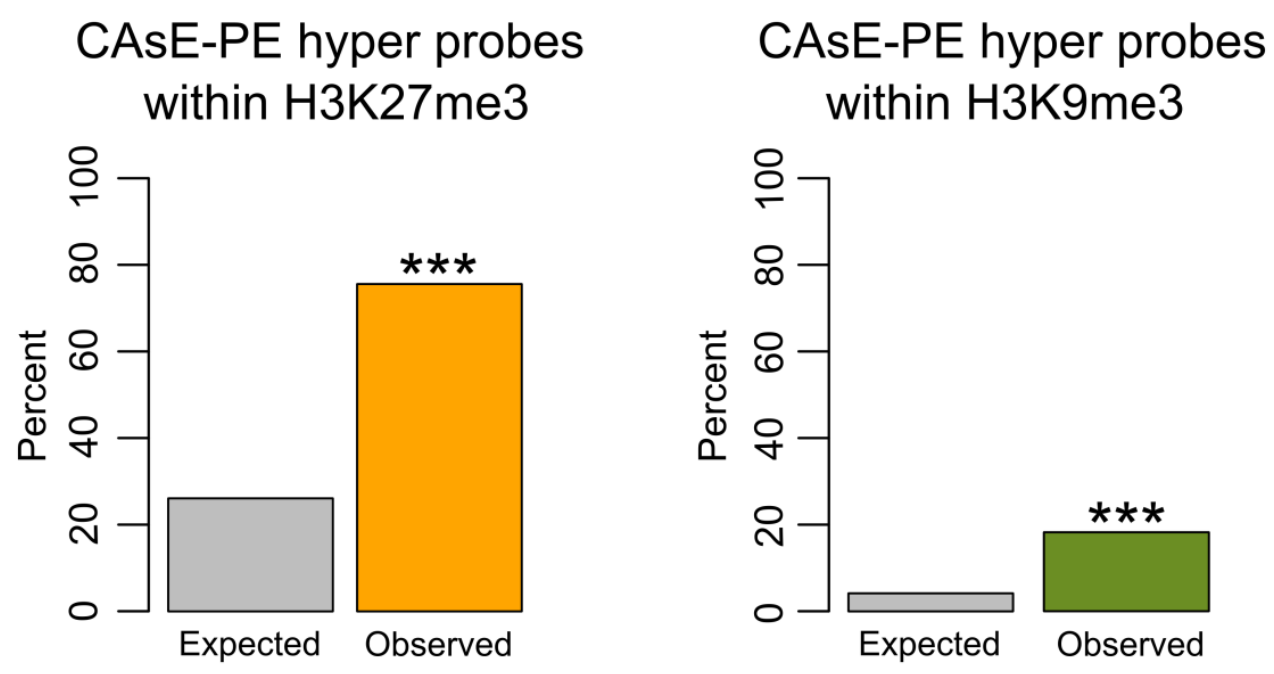

Figure 2.6. Total number of hypermethylated probes from CAsE-PE $(\mathrm{N}=2)$ that fall within $\mathrm{H} 3 \mathrm{~K} 27 \mathrm{me} 3$ or $\mathrm{H} 3 \mathrm{~K} 9 \mathrm{me} 3$ stem cell domains. 76 percent of the hypermethylated probes are within H3K27me3 domains (orange) when only 27 percent were expected. Eighteen percent of the hypermethylated probes are within $\mathrm{H} 3 \mathrm{~K} 9 \mathrm{me} 3$ domains (green) when only 4 percent are expected $\left(* * * \mathrm{p} \leq 1 \times 10^{-16}\right.$, hypergeometric test). 
Next we assessed whether the CAsE-PE agglomerative DNA methylation events associate with genomic regions enriched with $\mathrm{H} 3 \mathrm{~K} 27 \mathrm{me} 3$ or $\mathrm{H} 3 \mathrm{~K} 9 \mathrm{me} 3$ stem cell domains. To do this we scanned the portion of the genome covered by the human promoter microarray for extended regions that were enriched with these domains and compared them to the locations of the agglomerative DMRs. Enriched regions of hESC H3K27me3 domains partially overlapped the CAsE-PE agglomerative events in an expected manner considering that hESC H3K27me3 domains cover almost 27 percent of the microarray. There was a striking overlap of the H3K9me3 enriched regions with the agglomerative DNA methylation events. Figure 2.4 shows in green the genomic locations where there is a significant enrichment of $\mathrm{hESC} \mathrm{H} 3 \mathrm{~K} 9 \mathrm{me} 3$ domains. In the CAsE-PE cells, all three of the agglomerative DNA methylation events overlap with significant peaks of hESC H3K9me3 domain enrichment (Figure 2.4). These occur at the HOXD cluster on chromosome 2, the PCDH cluster on chromosome 5 and the HOXC cluster on chromosome 12. These overlaps suggest a potential connection between H3K9me3 stem cell domains and agglomerative DNA methylation.

\section{Discussion}

This study reports agglomerative DNA hypermethylation in toxicant-transformed cell lines, linking chronic arsenic and cadmium exposures in vitro with hypermethylation of large chromosomal regions. This new association supports the hypothesis that epigenetic dysfunction plays an important role in arsenic-induced malignant transformation because the agglomerative events are clinically relevant, occurring in 
human tumor samples (Table 2.3). Agglomerative DNA hypermethylation is one modification that is sometimes involved in LRES (Rauch 2007, Novak 2008, Novak 2006). LRES events have been observed in various human tumors and they reduce the transcriptional plasticity of groups of consecutive genes (Coolen 2010). While this study does not specifically address transcriptional silencing caused by these arsenic-induced agglomerative events, it does identify regions that are known sites of LRES in other models (Novak 2008, Novak 2006, Dallosso 2009, Dallosso 2012). We suspect that agglomerative DNA methylation often occurs at genes whose expression is already repressed by some other mechanism. Based on this study, we propose that while the agglomerative DNA methylation events are not always driving gene expression changes, they may represent deep epigenomic scars left by malignancy driving catastrophic events caused by toxicant exposure.

The agglomerative DNA hypermethylation events which occur at the PCDH and HOXC clusters were independently induced during arsenite, cadmium and MNU mediated malignant transformations, suggesting that they are reproducible events (Figure 2.4, Table 2.3). Therefore, the RWPE-1/CAsE-PE cell line model can be used as a tractable system in which to study the mechanisms involved in agglomerative DNA methylation and LRES, especially in the candidate regions found here such as the HOX and PCDH gene family clusters. The reproducibility of these events by distinct toxicants also suggests that each perturbs some common pathways involved in epigenetic dysfunction. Such a pathway could be related to the strong associations found between the H3K27me3 and H3K9me3 stem cell domains and aberrant DNA methylation. In 
general, there appear to be genomic locations which are highly susceptible to aberrant DNA methylation during toxicant-mediated malignant transformation.

In the arsenical-transformed UROtsa models we observed only one potential region of agglomerative DMRs (Table 2.3), which occurs at the HOXB gene family cluster. The lack of agglomerative DNA methylation events in the arsenical-transformed UROtsa cells relative to CAsE-PE appears related to the epigenetic state of the parental UROtsa prior to arsenic exposure. The pathway of events which gave rise to the immortal UROtsa cell line induced pronounced epigenetic remodeling. This is apparent in the comparison of UROtsa with HUC, which shows that agglomerative DNA methylation events are present in the UROtsa cells prior to any arsenic exposure (Table 2.3). This finding is not unprecedented since others have also observed agglomerative DNA methylation associated with catastrophic events such as overcoming stasis or immortalization (Novak 2009). This can help explain why arsenic did not induce as many agglomerative events in the arsenical-transformed UROtsa models compared to CAsE-PE, because genomic regions likely targeted for agglomerative DNA methylation during arsenic exposure were already hypermethylated in the parental UROtsa. These observations also highlight RWPE-1 as a valuable model to study the epigenetic mechanisms of toxicant-induced malignant transformation because its DNA methylation profile is relatively normal despite being an immortalized cell line.

Several important similarities and connections exist between stem cells and cancer cells which support an epigenetic comparison of these distinct cell types (reviewed 
in (Reya 2001) ). First, both exhibit self-renewal capability. Second, cancer cells often lose the terminally differentiated phenotype of their normal tissue counter-parts to resemble undifferentiated or stem cells. Finally, all normal differentiated cells and cancer cells are descendants of stem cells. These similarities and observations provide rationale for a comparison of the distinct epigenetic states between normal embryonic stem cells and our malignantly transformed models and suggest that the epigenetic state of malignant cells could be related to or partially determined by that of their stem cell ancestors.

As expected, we found that hESC H3K27me3 domains significantly overlapped individual hyper DMRs that arise during toxicant-induced malignant transformation (Figure 2.6). An association between H3K27me3 domains and aberrant DNA methylation in cancer has been described previously, which lends support to our data analysis because it conforms with the findings of several other studies (Wu 2010b, Ohm 2007, Schlesinger 2007). When we compared the enrichment of hESC H3K27me3 and hESC H3K9me3 domains to CAsE-PE agglomerative DNA methylation only the H3K9me3 enriched regions had a striking overlap with the agglomerative DMRs (Figure 2.4). This supports the link between $H 3 K 27$ me 3 and aberrant hypermethylation of individual genes, but in the case of agglomerative hypermethylation, $\mathrm{H} 3 \mathrm{~K} 9 \mathrm{me} 3$ may be a more important player.

The significant overlaps observed between hESC H3K9me3 enriched domains and the toxicant-induced agglomerative DMRs suggest that $\mathrm{H} 3 \mathrm{~K} 9$ me3 modifications may 
be involved in directing aberrant DNA methylation to these regions. While the association of aberrant DNA methylation with $\mathrm{H} 3 \mathrm{~K} 9 \mathrm{me} 3$ in humans is rather new, normal mechanisms are known which link these two epigenetic modifications. For example, both are hallmarks of normal mammalian heterochromatin and the histone methyltransferases Suv39h and G9a have been shown to recruit DNA methyltransferases which can lead to spreading of DNA methylation in normal cells (Epsztejn-Litman 2008, Lehnertz 2003, Fuks 2003). On the other hand, there must also be normal mechanisms leading to $\mathrm{H} 3 \mathrm{~K} 9 \mathrm{me} 3$ that do not induce DNA methylation since many H3K9me3 domains in normal cells are not DNA methylated (Edwards 2010). Perhaps during malignant transformation there are aberrant interactions between histone methyltransferases and DNA methyltransferases (e.g. Suv39h and DNMT3B) that lead to aberrant DNA methylation of H3K9me3 domains that are normally unmethylated. Once such a region contains aberrant DNA methylation, $\mathrm{H} 3 \mathrm{~K} 9 \mathrm{me} 3$ and its associated factors may induce further spreading of the aberrant methylation to result in an agglomerative region of aberrant DNA methylation (Lehnertz 2003, Fuks 2003).

In conclusion, agglomerative DNA methylation is associated with toxicantinduced malignant transformation. Overall, this study suggests that there are common pathways of epigenetic dysfunction in distinct models transformed by arsenic, cadmium or MNU which target both individual genes as well as larger chromosomal regions that contain many genes. Individual DMRs are likely to occur in H3K27me3 domains while the agglomerative DNA methylation may be targeted to $\mathrm{H} 3 \mathrm{~K} 9 \mathrm{me} 3$ domains. These 
associations provide further insights into the epigenetic mechanisms of toxicant-induced malignant transformation and carcinogenesis in general. 


\section{CHAPTER 3: COORDINATE H3 LYSINE 9 AND DNA METHYLATION SILENCING OF ZNF CLUSTERS DURING TOXICANT-INDUCED MALIGNANT TRANSFORMATION}

Text and Figures in this section are derived from: Severson PL, Tokar EJ, Vrba L, Waalkes MP, Futscher BW, prepared for publication in the journal Epigenetics.

\section{Introduction}

One important function of epigenetics is to provide a mechanism of genomic plasticity so that cells may respond to a changing and potentially harmful environment. Global disruption of the epigenetic code is a hallmark of malignancy that encompasses many distinct modifications that are highly interactive. For instance, during normal differentiation, histone $\mathrm{H} 3$ lysine 9 trimethylation (H3K9me3) acts as a substrate for heterochromatin binding proteins that recruit DNA methyltransferases thereby directing DNA methylation to specific genomic elements (Epsztejn-Litman 2008, Lehnertz 2003). Another repressive histone modification, H3 lysine 27 trimethylation (H3K27me3), predetermines a majority of the aberrant de novo DNA methylation sites in cancer (Schlesinger 2007) most likely through protein-protein interactions which recruit DNA methyltransferases (Vire 2006). On the other hand, trimethylation of histone H3 lysine 4 ( $\mathrm{H} 3 \mathrm{~K} 4 \mathrm{me} 3)$ is found at the promoters of actively transcribed genes where it aids in the formation of an active chromatin conformation and prevents DNA methylation (Ooi 2007). Although some may function as individual enzymes, most epigenetic modifying proteins work as members of higher order protein complexes which may often contain several epigenetic modifying enzymes, collectively controlling many distinct epigenetic 
marks. Generally, when one epigenetic mark is pathologically disrupted, several others are likely to be altered as a result. By characterizing the interplay between epigenetic modifications in toxicant-associated malignant transformation we can decipher whether there are likely to be few fundamental pathways that are frequently disrupted in cancer that drive widespread epigenetic malfunction.

The $\mathrm{C} 2 \mathrm{H} 2$ zinc finger genes (ZNFs) make up one of the largest families of sequence specific DNA binding transcriptional repressors. At least a third of ZNF genes contain the KRAB domain (KRAB-ZNFs) which is known to interact with the KAP1 protein and indirectly recruit histone and DNA methyltransferases to specific genomic sequences that become marked with $\mathrm{H} 3 \mathrm{~K} 9 \mathrm{me} 3$ and DNA methylation as a result (Rowe 2013, Quenneville 2012, Groner 2010). In non-malignant cells, this targeted repressive activity of ZNFs participates in important anti-cancer defenses including regulation of cell proliferation and silencing of endogenous retroviruses (Huang 2006, Rowe 2010, Rowe 2013). Because ZNFs are indirectly responsible for recruitment of distinct epigenetic modifying enzymes they represent a potential common pathway that when disrupted would alter multiple epigenetic marks at specific genomic loci.

Previous studies have identified global DNA methylation and histone modification changes that occurred in toxicant-treated, malignant cell lines relative to their untreated, immortal counterparts (Jensen 2008, Jensen 2009a, Wnek 2010, Severson 2012). These models suggested that non-mutagenic environmental toxicants, such as arsenic, could induce aberrant agglomerative DNA methylation events during malignant transformation (see Chapter 2). We also found that in all the malignant cell lines and 
tumor biopsies tested, DNA hypermethylation occurred disproportionately within H3K27me3 and H3K9me3 stem cell domains with a striking correlation between densely packed $\mathrm{H} 3 \mathrm{~K} 9 \mathrm{me} 3$ stem cell domains and aberrantly methylated gene family clusters (see Chapter 2). Finding that DNA hypermethylation occurred disproportionately within $\mathrm{H} 3 \mathrm{~K} 27 \mathrm{me} 3$ and $\mathrm{H} 3 \mathrm{~K} 9 \mathrm{me} 3$ domains was expected, as these histone modifications are known to be linked to DNA methylation in certain scenarios (Vire 2006, Epsztejn-Litman 2008). In the context of gene promoters, $\mathrm{H} 3 \mathrm{~K} 27 \mathrm{me} 3, \mathrm{H} 3 \mathrm{~K} 9 \mathrm{me} 3$ and DNA methylation are each known to participate in transcriptional repression, which led us to investigate the relationships between $\mathrm{H} 3 \mathrm{~K} 27 \mathrm{me} 3, \mathrm{H} 3 \mathrm{~K} 9 \mathrm{me} 3$, aberrant DNA methylation and gene expression changes in environmental toxicant-associated malignant transformation.

In this pursuit, we have expanded on earlier studies by incorporating gene expression and selected chromatin immunoprecipitation analyses of the immortal prostate epithelial cell line RWPE-1 and its arsenic-exposed malignant variant, CAsE-PE, to better understand the relationships between aberrant DNA methylation, H3K9me3, H3K27me3 and gene expression of individual genes and gene family clusters in toxicantassociated malignant transformation. Our results confirm that $\mathrm{H} 3 \mathrm{~K} 27 \mathrm{me} 3$ marked genes are targeted for aberrant DNA methylation and remain inactive. Contrarily, in immortalized cells we found that ZNFs in particular are frequently marked with H3K9me3 on their 3' exons and $\mathrm{H} 3 \mathrm{~K} 4 \mathrm{me} 3$ at the 5' ends while actively transcribed (Blahnik 2011). However, after malignant transformation, H3K9me3 had replaced H3K4me3 at the promoters of ZNFs and was accompanied by aberrant DNA methylation, resulting in a widespread down-regulation of ZNF gene expression. 


\section{Materials and Methods}

\section{MeDIP-on-Chip data analysis}

Microarray data were processed as described in Chapter 2. In this study, a less stringent $p$-value cut off of 0.01 was used which maintained the false discovery rate $(\mathrm{FDR}) \leq 5 \%$. The FDR was determined by analysis of permutated data. DMRs were calculated between RWPE-1 and CAsE-PE samples. The coverage of the Human Promoter ChIP-on-Chip Microarray Set 244K was annotated to individual genes and a gene was considered differentially methylated when its annotated region contained or overlapped a DMR. Gene set enrichment analyses of hypermethylated genes were performed using the GOstats package in R (Falcon and R. Gentleman 2007).

Analysis of gene expression change

Three biological replicates of RWPE-1 and 3 replicates of CAsE-PE were grown until they reached approximately $80 \%$ confluence in $25 \mathrm{~cm} 2$ flasks. Total RNA was isolated from each flask and concentrations and quality were determined using absorbance at A260 and A280 followed by analysis on an Agilent Nanochip (Agilent Technologies). RNA samples were used to produce labeled target, hybridized to Affymetrix GeneChip ${ }^{\circledR}$ Human Gene 1.0 ST Arrays, and read using an Affymetrix scanner according to the manufacturer's protocols. Raw data (CEL files) were normalized and summarized according to Irizarry et al. (2003) (Irizarry 2003), as implemented in package aroma.affymetrics (Bengtsson 2008). Differential expression was tested using the package LIMMA in the $\mathrm{R}$ programming environment (Smyth 2005). All p-values were adjusted according to Benjamini and Hochberg's method 
to control the false discovery rate using a global method. Differential gene expression was defined as a fold change $\geq 2$ and adjusted $p$-value $\leq 0.05$. Several gene expression changes were confirmed by quantitative reverse-transcription (QRT)-PCR as described previously (Jensen 2008).

Merging DNA methylation data with gene expression data

DNA Methylation data were merged with gene expression data by calculating the average methylation differences within $2 \mathrm{~kb}$ windows centered on TSSs of genes that had 5 or more MeDIP-on-Chip probes within the $2 \mathrm{~kb}$ window.

\section{Chromatin immunoprecipitation}

Chromatin immunoprecipitations (ChIPs) were performed using the MAGnify Chromatin Immunoprecipitation system (Life Technologies, 49-2024) according to the manufacturer's protocol with the following adjustments. Antibodies against H3K4me3 (Millipore, 05-745R), H3K27me3 (Cell Signaling, C36B11) and H3K9me3 (Diagenode, MAb-146-050) were used for chromatin immunoprecipitation. Cells were grown in 10cm dishes, washed with Hank's Balanced Salt Solution (HBSS) and then crosslinked by adding $5 \mathrm{ml}$ of HBSS with $1 \%$ formaldehyde for 8 minutes at room temperature. The crosslinking reaction was stopped by adding $500 \mathrm{uL}$ of $1.25 \mathrm{M}$ glycine and incubating 5 minutes. Dishes were washed $2 \mathrm{X}$ with $5 \mathrm{~mL}$ HBSS and then the cells were scraped from the dishes in two steps using $2.5 \mathrm{~mL}$ of HBSS with 2\% FBS, 0.1\% EDTA and protease inhibitors for each scraping. Chromatin was sheared by sonication in a chilled Bioruptor (Diagenode) set to high for 42 cycles of 30 seconds on/off. Approximately 200,000 cells were used for each ChIP. Input DNA was purified from a sample aliquot equal to $10 \%$ of 
the total cells used for each ChIP. Equal volumes of ChIP and input DNA were quantified by Q-PCR using the ABI 7500 Real-Time Detection System. One sided Wilcoxon rank sum tests were used for statistical calculations.

\section{Results}

To interpret global DNA methylation changes associated with malignant transformation we performed MeDIP-on-Chip on 2 replicates of CAsE-PE and 2 replicates of RWPE-1 using Agilent Human promoter ChIP-on-Chip microarrays. This microarray probes the genomic regions between $5.5 \mathrm{~kb}$ upstream and $2.5 \mathrm{~kb}$ downstream of the transcription start sites of approximately 17,000 annotated human genes (Figure 3.1A). Therefore, the probes are well positioned to detect DNA methylation changes that occur in close proximity to TSSs of protein coding genes but any genomic elements which are far from gene promoters have minimal coverage. With this probe distribution the microarray is more likely to detect hypermethylation events associated with malignant transformation since the DNA of normal cells is generally unmethylated near transcription start sites. In agreement with the array distribution and the general profile of DNA methylation at gene promoters in cancer, our final MeDIP-on-Chip dataset of CAsE-PE relative to RWPE-1 contained predominately DNA hypermethylation events occurring near TSSs while DNA hypomethylation events were fewer and more evenly distributed through the regions analyzed (Figure 3.1A). 
A

Distribution of MeDIP-on-Chip Probes Relative to TSSs

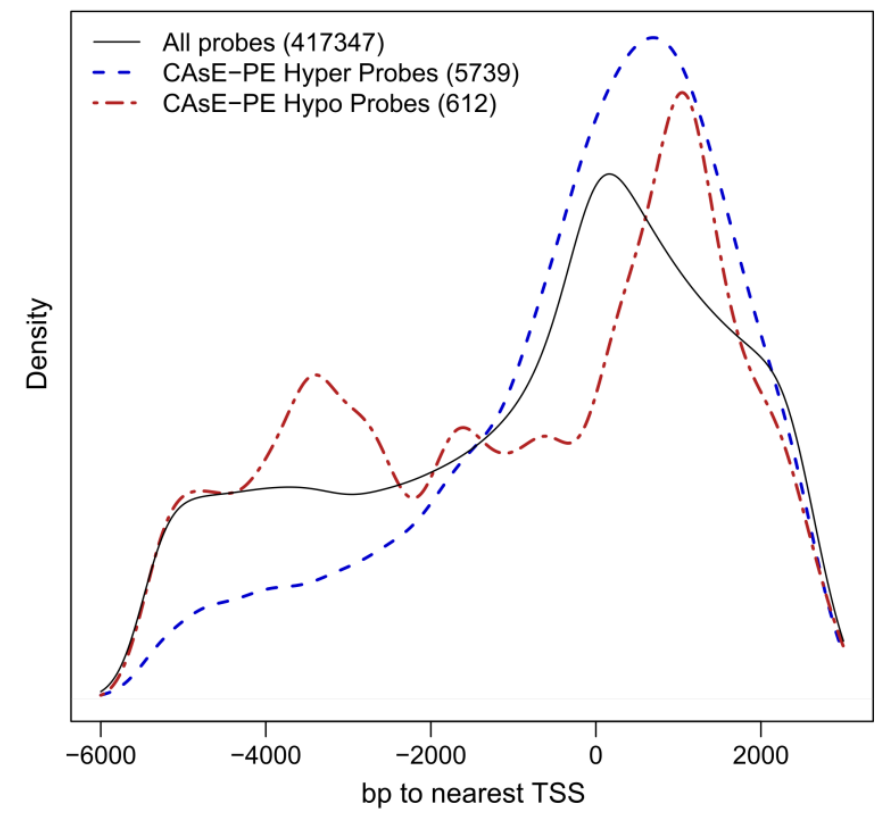

B

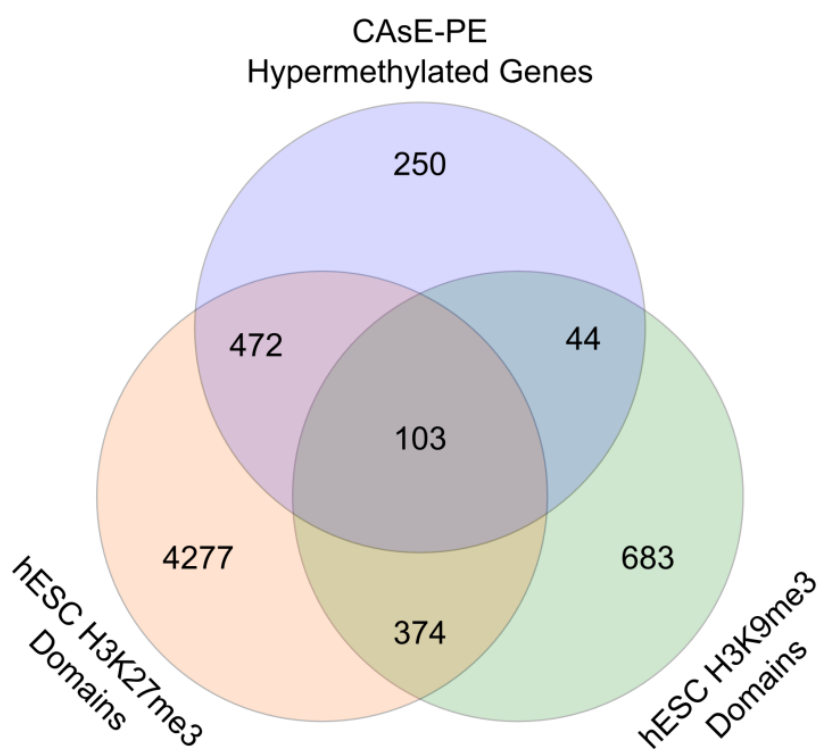

Figure 3.1 (A) The black solid line represents the distribution of all the MeDIP-on-Chip microarray probes relative to their nearest transcription start site. Blue and red dashed lines show the distribution of hyper and hypo methylated probes respectively. The same bandwidth was used for smoothing each curve. (B) Venn Diagram showing the genes hypermethylated in CAsE-PE, hESC H3K27me3 domains and hESC H3K9me3 domains. 
Hypermethylated genes share common ontologies

Overall, the MeDIP-on-Chip detected 869 hypermethylated and 166 hypomethylated genes in CAsE-PE cells. Most of the genes hypermethylated in CAsE$\mathrm{PE}$ are $\mathrm{H} 3 \mathrm{~K} 27 \mathrm{me} 3$ marked in human embryonic stem cells (hESC), an observation that was discussed in Chapter 2 (Figure 3.1B). Several of the aberrant DNA methylation events detected by MeDIP-on-Chip were confirmed by MassARRAY technology (Figure 3.2). To determine if particular classes of genes were targeted for hypermethylation arsenite-transformed cells, we performed a gene set enrichment analysis. Results showed that genes involved in developmental processes, and genes which are DNA or chromatin binding transcription factors were targeted for DNA hypermethylation in CAsE-PE (Appendix B.). This could mean that these genes were selected for hypermethylation by nature of their function, which when silenced by methylation conferred some growth advantage to the cells. When taking into account that H3K27me3 domains of stem cells are targeted for aberrant DNA methylation in cancer, a more likely explanation is that these functional categories of genes are aberrantly methylated because they are normally regulated by the same epigenetic mechanisms, including H3K27me3 (Figure 3.1B) (Widschwendter 2007). 


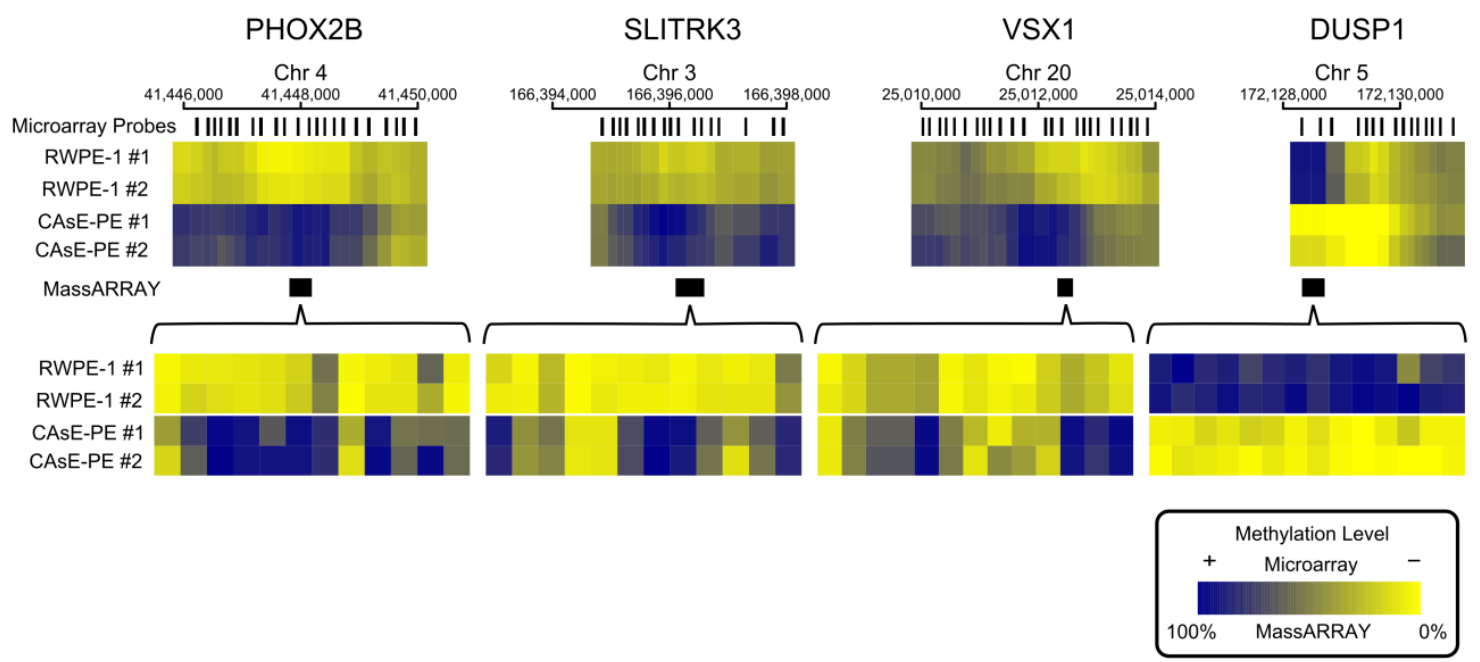

Figure 3.2 MassARRAY technology was used to confirm the DNA methylation changes that were measured by MeDIP-on-Chip. Top: MeDIP-on-Chip data where \#1 and \#2 refer to the individual replicates. Black bars mark the genomic locations that were analyzed by MassARRAY. Bottom: MassARRAY data for the corresponding genomic locations. Results from this Sequenom analysis confirm select hyper- and hypomethylation results obtained in the MeDIP-on-Chip analysis. 
Widespread down-regulation of ZNFs in CAsE-PE

In addition to DNA methylation profiling, we also performed gene expression profiling to identify changes that were associated with the malignant phenotype of CAsEPE. We measured global gene expression levels in 3 replicates of CAsE-PE and 3 replicates of RWPE-1 using the Affymetrix Human Gene ST 1.0 microarray platform. Based on the criteria of fold change $\geq 2$ and adjusted $p$-value $\leq 0.05$, we found 428 downregulated and 514 up-regulated genes in the malignant CAsE-PE cells relative to the nonmalignant RWPE-1. We found several gene expression changes that have been linked to cancer progression of the prostate and other tissues and we used QRT-PCR to confirm a small representative set (Figure 3.3). Surprisingly, there was a highly significant downregulation of $\mathrm{ZNF}$ and $\mathrm{KRAB}-\mathrm{ZNF}$ genes, comprising almost $8 \%$ of all the downregulated genes. Thirty four out of the total $519 \mathrm{ZNF}$ genes covered by the expression array were significantly down-regulated and 26 of these were KRAB-ZNF genes ( $\mathrm{p}<1 \times 10-12$, hypergeometric test of ZNFs). Over-representation of the ZNFs and particularly the KRAB-ZNFs among the down-regulated genes suggests that they are being silenced in a coordinated fashion which may be driven by a common epigenetic mechanism and that their broad silencing could have a substantial impact on the phenotype of CAsE-PE cells. 

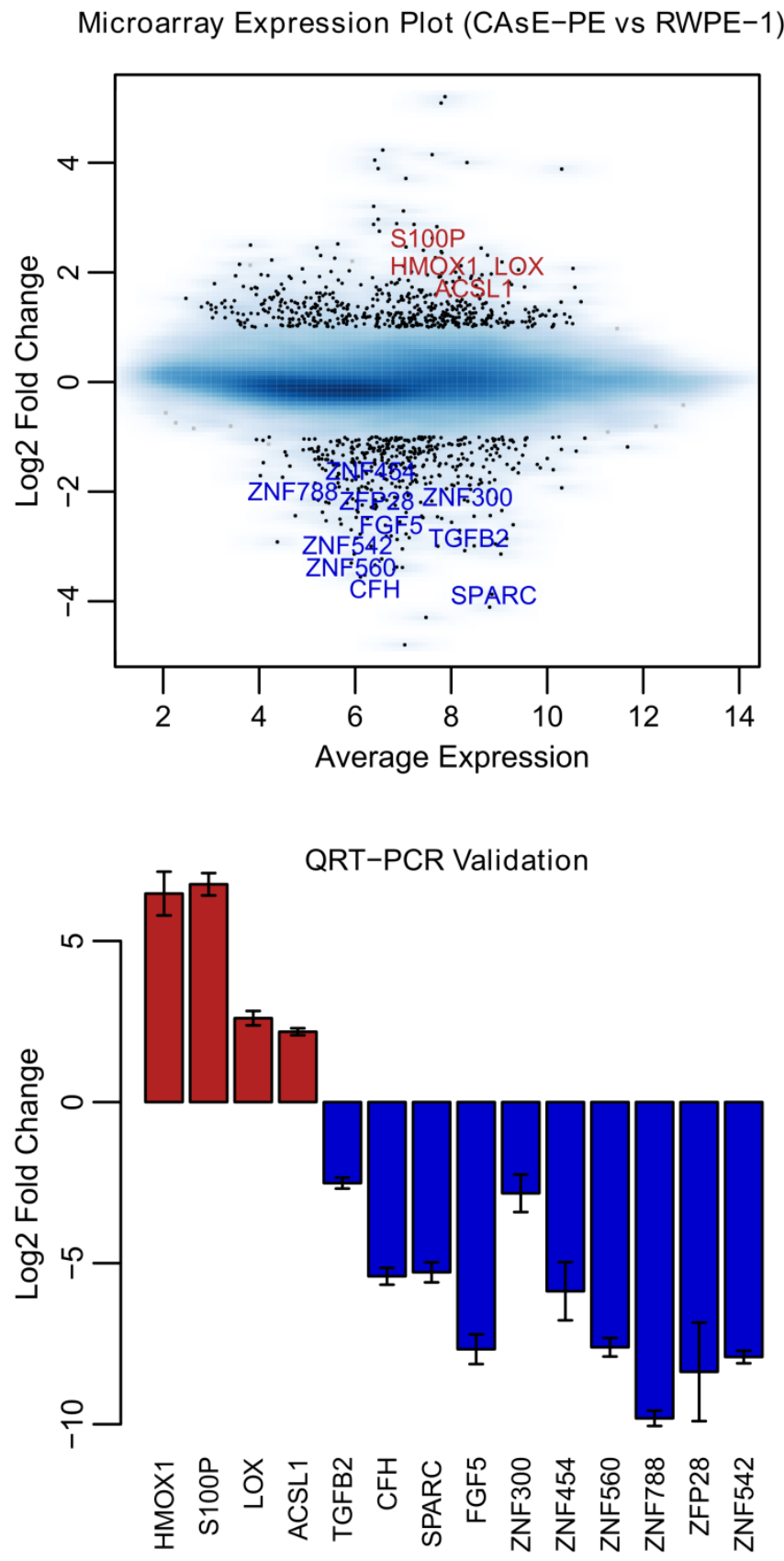

Figure 3.3 (Top) Plot of the Affymetrix Human Gene Expression dataset. Three replicates of CAsE-PE were compared to three replicates of RWPE-1. Each black dot represents a differentially expressed gene. Fourteen differentially expressed genes are labeled. (Bottom) Fourteen of the differentially expressed genes measured by microarray were validated by QRT-PCR. Expression levels for each of the 14 genes were significantly different in CAsE-PE relative to RWPE- 1 ( $p=0.05$, Wilcoxon rank sum test). 
A negative correlation between DNA methylation and gene expression is driven by hypermethylation of ZNF gene promoters

Cancer-associated, DNA hypermethylation occurs disproportionately in H3K27me3 (Schlesinger 2007) and H3K9me3 domains (see Chapter 2), leading us to question how each of these potential targeting mechanisms would affect cellular phenotype since both these histone modifications and DNA methylation at gene promoters repress transcription. To begin to address this question we determined to what degree the DNA methylation changes correlated with gene expression changes. We merged the MeDIP-on-Chip data with the expression data by calculating the methylation changes within $2 \mathrm{~kb}$ windows centered on TSSs. Plotting the DNA methylation change relative to the gene expression change showed that they were negatively correlated which indicates that hypermethylation does not only occur at genes that are already silenced by H3K27me3 or H3K9me3 (Figure 3.4). Forty six genes were significantly down-regulated and had a $\log 2$ fold DNA methylation increase greater than 0.5 (Figure 3.4, blue text). Some of the genes that met these criteria are LAMB2, ANXA6, SLC4A11, UCHL1, FGF5, PTGS2, SPARC and BDNF. Only three significantly upregulated genes were linked to DNA hypomethylation of the TSS (S100P, INSL6 and ADRB2, Figure 3.4). In all, about $9 \%$ of the gene expression changes observed were linked to DNA methylation changes, with almost all the changes being repressive.

It was readily apparent that many ZNFs were among the genes that were both hypermethylated and down-regulated. Twelve ZNF genes (ZNF542, ZNF300, ZNF560, ZNF454, ZNF471, ZNF667, ZFP28, ZFP42, ZSCAN18, ZNF677, ZIK1 and ZNF582), 9 
of which are KRAB-ZNFs, demonstrated significant down-regulation and increased DNA methylation ( $>0.5 \log 2$ fold change). Overall, silencing of ZNF genes represented a substantial portion (12 of 46, 26\%) of all the significant down-regulated genes in CAsEPE that were correlated with increased DNA methylation. 


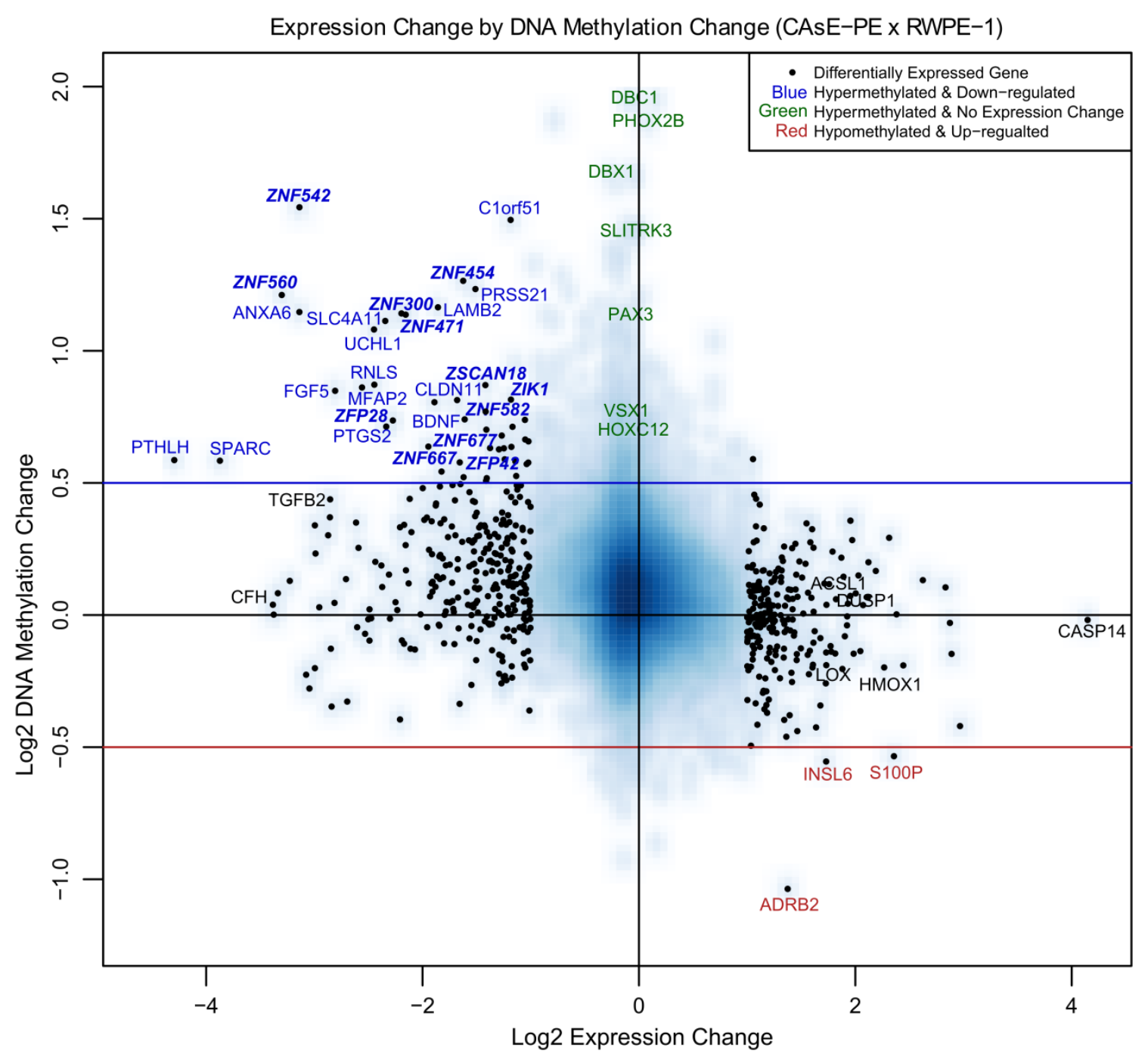

Figure 3.4 Expression by Methylation Plot. The blue-shaded background density cloud shows the distribution of all the genes covered by both arrays. Differentially expressed genes represented on both microarray platforms (553 genes, marked with black dots) were used to calculate a correlation between methylation change and expression change. Two-sided Spearman rank correlation coefficient $=-0.37$. Genes labeled with blue text had a significant decrease in expression and a $\log 2$ increase in methylation greater than 0.5 . Not all the genes that meet these criteria are labeled due to space limitations. Selected genes labeled with green text had minimal expression change and a log2 increase in methylation greater than 0.5 . Genes labeled with red text had a significant increase in expression and a $\log 2$ decrease in methylation greater than 0.5 . Selected genes labeled with black text are relevant in other sections of Chapter 3. 


\section{H3K27me3 domains are silent targets of aberrant DNA methylation}

After merging of the expression and methylation data sets it was apparent that many of the DNA hypermethylation events were not associated with changes in gene expression, since the target genes themselves were not expressed. In fact, genes associated with some of the most extensive DNA hypermethylation events such as PHOX2B and DBC1 experienced no expression change (Figure 3.4, green text). VSX1, SLITRK3, HOXC12 and PAX3 are other examples of highly significant DNA hypermethylation events with no expression change, which is understandable since this group of genes is expressed at low levels in the parental RWPE-1 cells. Chromatin immunoprecipitations determined that VSX1, HOXC12 and PHOX2B were marked with H3K27me3 in RWPE-1 and CAsE-PE cells (Figure 3.5). Overall, 92\% of the genes with increased promoter methylation were not down-regulated. While only a select few genes were verified as $\mathrm{H} 3 \mathrm{~K} 27 \mathrm{me} 3$ targets in our models, based on the large overlap between hESC H3K27me3 domains and CAsE-PE hypermethylated genes (Figure 3.1B) it is likely that a high proportion of the hypermethylated genes are H3K27me 3 marked in the parental RWPE-1. These data further support that H3K27me3 is a major factor in directing aberrant DNA methylation during malignant progression, but the phenotypic effects of this phenomenon are unknown since it has not been associated with gene expression changes. 


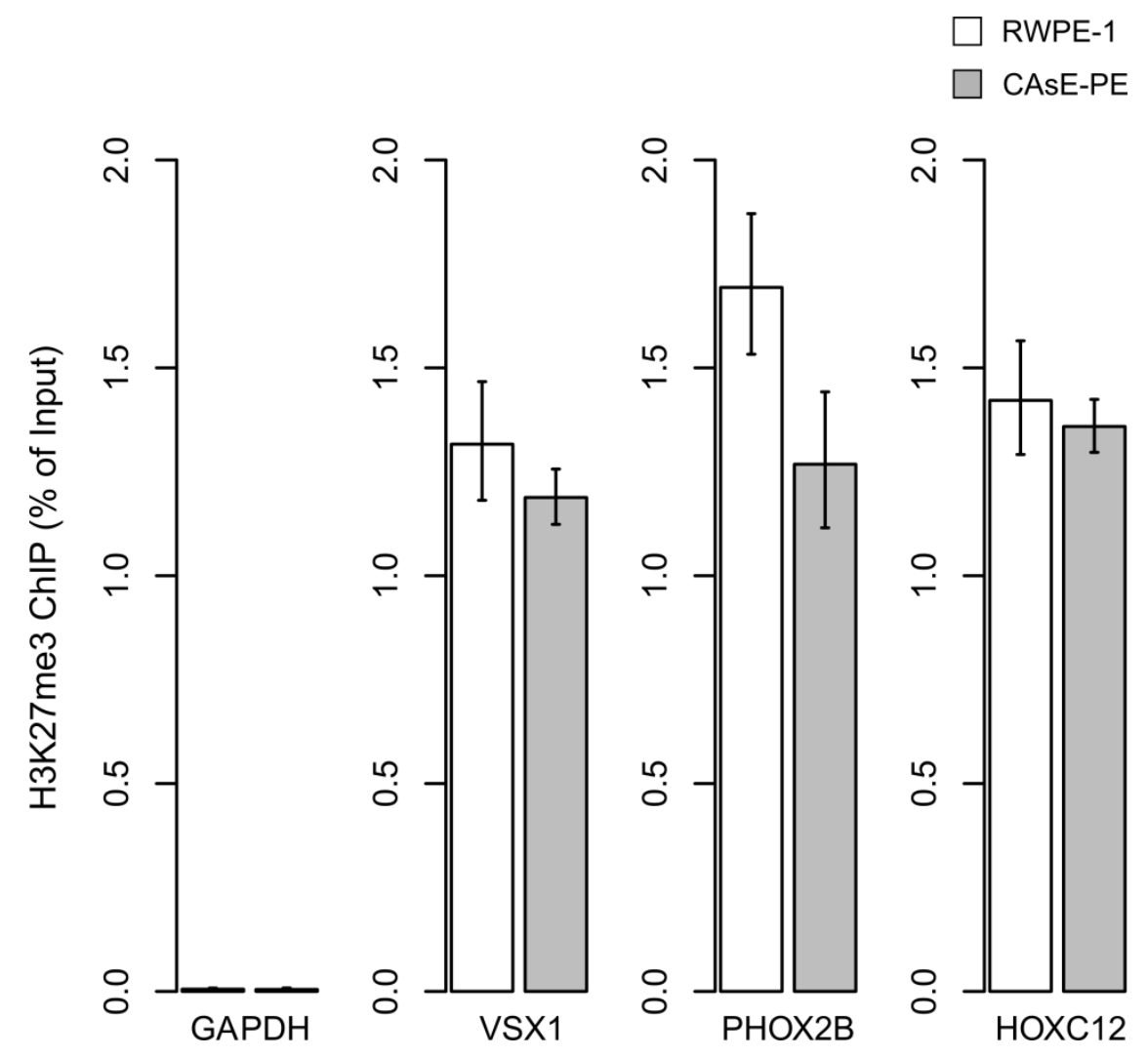

Figure 3.5 H3K27me3 target genes. H3K27me3 ChIPs were quantified by Q-PCR. Error bars represent the SEM of three experiments. GAPDH primers were used as a control to show ChIP levels of a H3K27me3 negative region. 
ZNF gene clusters associate with hESC H3K9me3 domains and are silenced by DNA hypermethylation

In contrast to aberrant DNA methylation targeting H3K27me3 pre-marked silent genes, we found that actively expressed ZNF genes that overlap hESC H3K9me3 domains are preferred targets of DNA methylation linked gene silencing. We found a major overlap of hESC H3K9me3 domains with ZNF genes, many of which were downregulated and DNA hypermethylated. Most of the human ZNF genes reside within one of the $81 \mathrm{ZNF}$ gene clusters across the human genome which are known to associate with H3K9me3 and heterochromatin binding proteins (O'Geen 2007, Vogel 2006).

Chromosome 19 is particularly rich with ZNF genes, accounting for about $44 \%$ of all the human ZNF genes including the largest ZNF gene cluster (19.13) with 76 ZNF genes. We found that 9 of the ZNF genes in cluster 19.13 were significantly hypermethylated while 10 were significantly down-regulated in CAsE-PE relative to RWPE-1 (Figure 3.6). Of the down-regulated ZNFs in this cluster, 5 contain hyper-DMRs while ZFP28 and ZNF667 have increased promoter DNA methylation that did not reach the strict DMR requirement (Figure 3.6). This entire cluster and most other ZNF gene clusters are hESC H3K9me3 domains (Figure 3.7A). ZNF gene cluster 19.7 was also significantly down-regulated and associated with $\mathrm{H} 3 \mathrm{~K} 9 \mathrm{me} 3$ stem cell domains, but the methylation data for this cluster is limited because it was poorly covered by the MeDIP-on-Chip microarray (Figure 3.7A). Four other ZNF clusters on chromosome 19 (19.12, 19.11, 19.6, 19.5) also had down-regulated and methylated ZNFs. Down-regulated, hypermethylated ZNFs were also found on other chromosomes, for example ZNF454, 
which is part of ZNF gene cluster 5.1 on chromosome 5, was hypermethylated, downregulated and associated with hESC H3K9me3 domains (Figure 3.7B). Likewise, ZNF300 on chromosome 5 was hypermethylated and down-regulated, but does not belong to a ZNF gene cluster (Figure 3.7B). In summary, while the data is limited, they suggest that ZNFs with unique connections to hESC H3K9me3 domains, are widely targeted for aberrant DNA hypermethylation and down-regulation during toxicantinduced malignant transformation. 


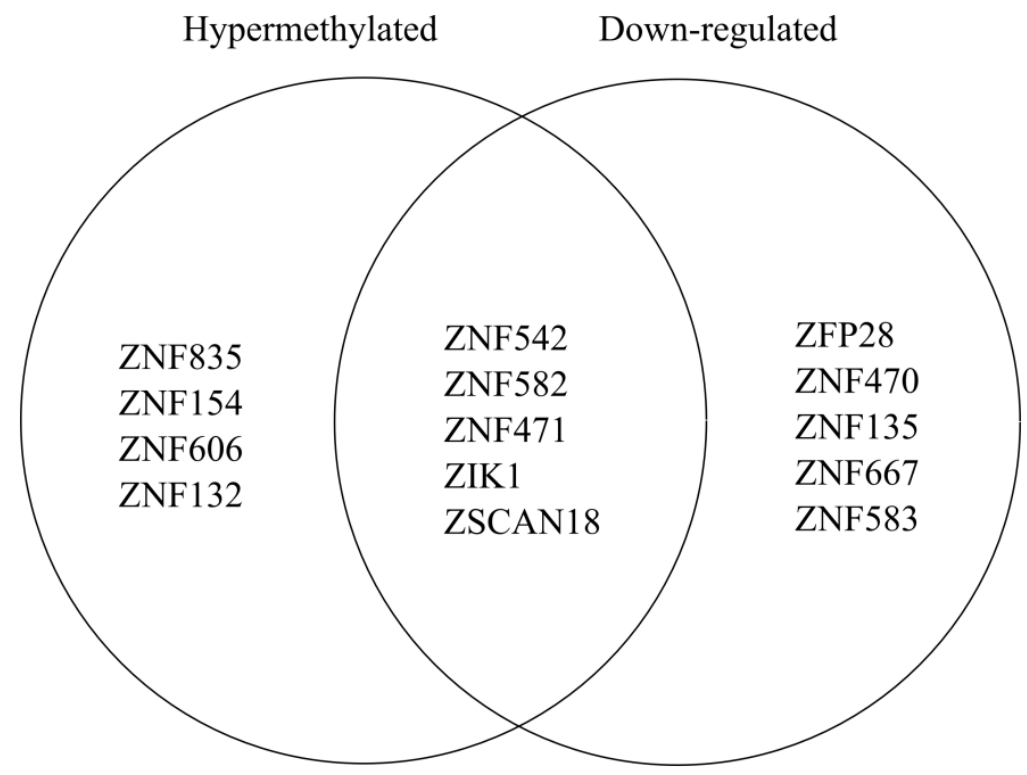

Figure 3.6 Venn diagram of ZNF genes in ZNF gene cluster 19.13 that are hypermethylated (i.e. contain a hyper DMR) or are down-regulated. 
A

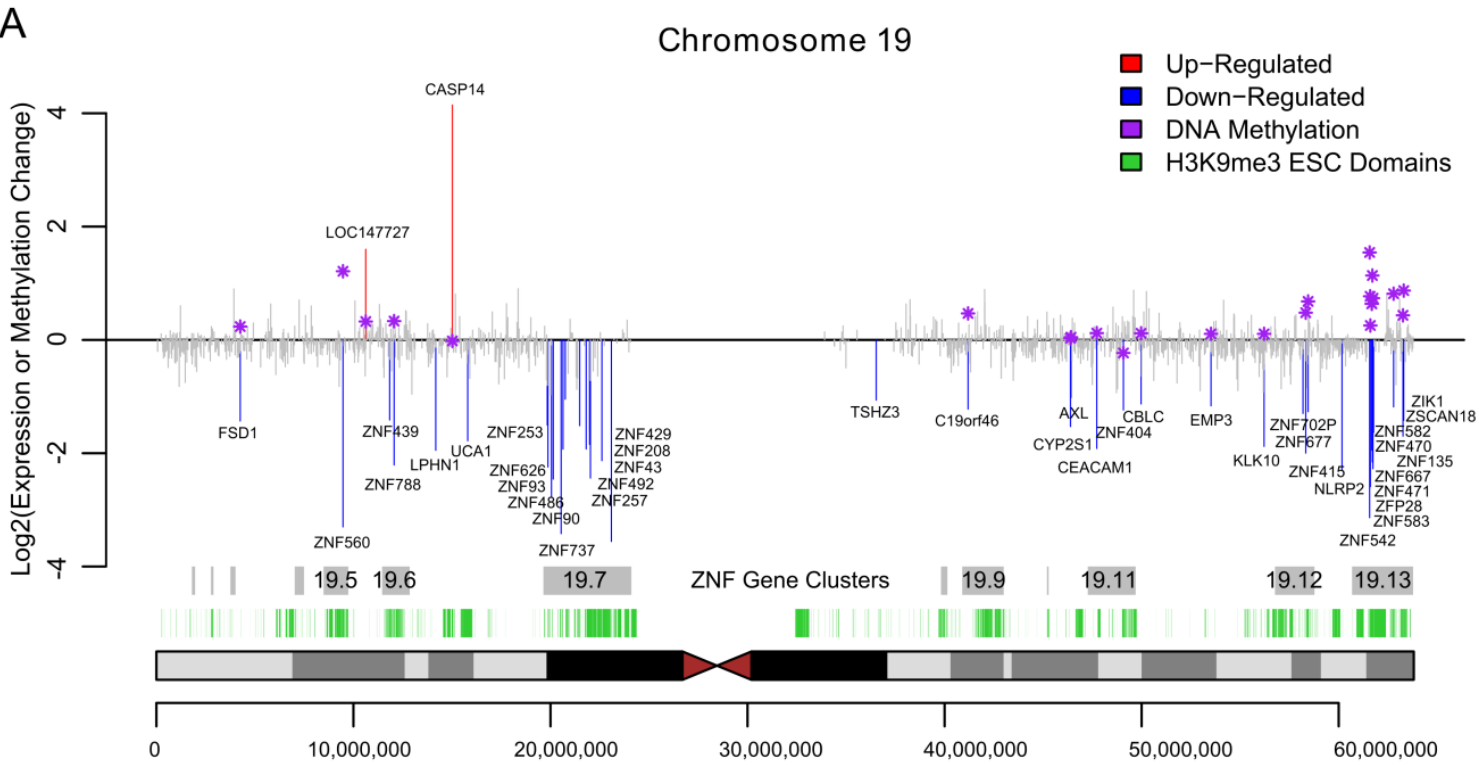

B

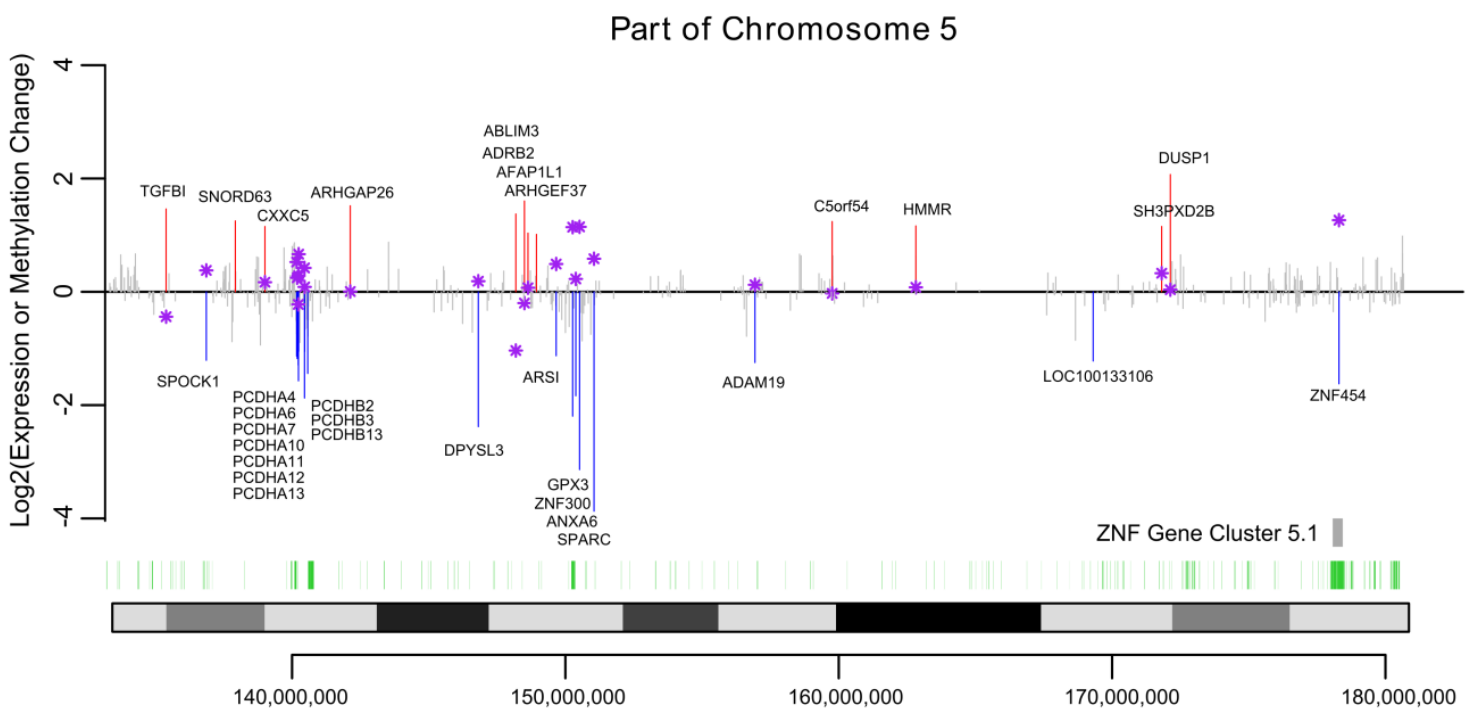

Figure 3.7 Expression and Methylation Changes in CAsE-PE. Significantly up-regulated genes or down-regulated genes are plotted in red or blue respectively. Purple stars show the methylation change at differentially expressed genes where available, measured within a $2 \mathrm{~kb}$ window centered on the TSS. Grey boxes mark the ZNF gene family clusters and green boxes mark H3K9me3 stem cell domains. (A) Chromosome 19. (B) Portion of Chromosome 5q. 
Aberrant spreading of $\mathrm{H} 3 \mathrm{~K} 9 \mathrm{me} 3$ is linked to DNA methylation and gene silencing

One would expect little to no transcription from genes associated with H3K9me3 since this histone modification induces heterochromatin formation and gene silencing. Therefore, it would seem contradictory for ZNF genes to be expressed in RWPE-1 cells and associated with domains commonly marked with $\mathrm{H} 3 \mathrm{~K} 9 \mathrm{me} 3$ in other cell types. As a resolution to this contradiction, work by Blahnik et al. showed that in somatic cells, actively expressed ZNF genes are marked by H3K9me3 primarily at their 3' exons rather than the entire gene (Blahnik 2011). Based on this information we analyzed the histone methylation patterns at the 5' and 3' ends of several ZNF genes that were silenced by DNA methylation in CAsE-PE. Histone methylation levels were measured by ChIP at ZNF542, ZNF471 and ZFP28 all of which pertain to ZNF gene cluster 19.13 (Figure 3.8). In parental RWPE-1 cells we found that the 3' end of each of these genes was marked with $\mathrm{H} 3 \mathrm{~K} 9 \mathrm{me} 3$ whereas at the 5' ends of the genes $\mathrm{H} 3 \mathrm{~K} 4 \mathrm{me} 3$ was present and H3K9me3 was absent. In the malignantly transformed CAsE-PE cells, H3K4me3 had been replaced by H3K9me3 at the 5' ends of all three genes (Figure 3.8). This same pattern of exchange was found at the ends of ZNF560 in ZNF cluster 19.5 (Figure 3.9). This suggests that during arsenic induced malignant transformation, H3K9me3 spreads from the 3' exons of expressed ZNF genes to the 5' end near the promoter leading to gene silencing and DNA methylation. This was also observed for ZNF genes on chromosome 5 which experienced exchange of $\mathrm{H} 3 \mathrm{~K} 9 \mathrm{me} 3$ for $\mathrm{H} 3 \mathrm{~K} 4 \mathrm{me} 3$ at their 5 ' ends, DNA hypermethylation and down-regulation in CAsE-PE (Figure 3.9). Together, these data show that in malignant cells, individual ZNF genes and entire ZNF gene clusters 
across different chromosomes are silenced by spreading of H3K9me3 and DNA hypermethylation. 
A
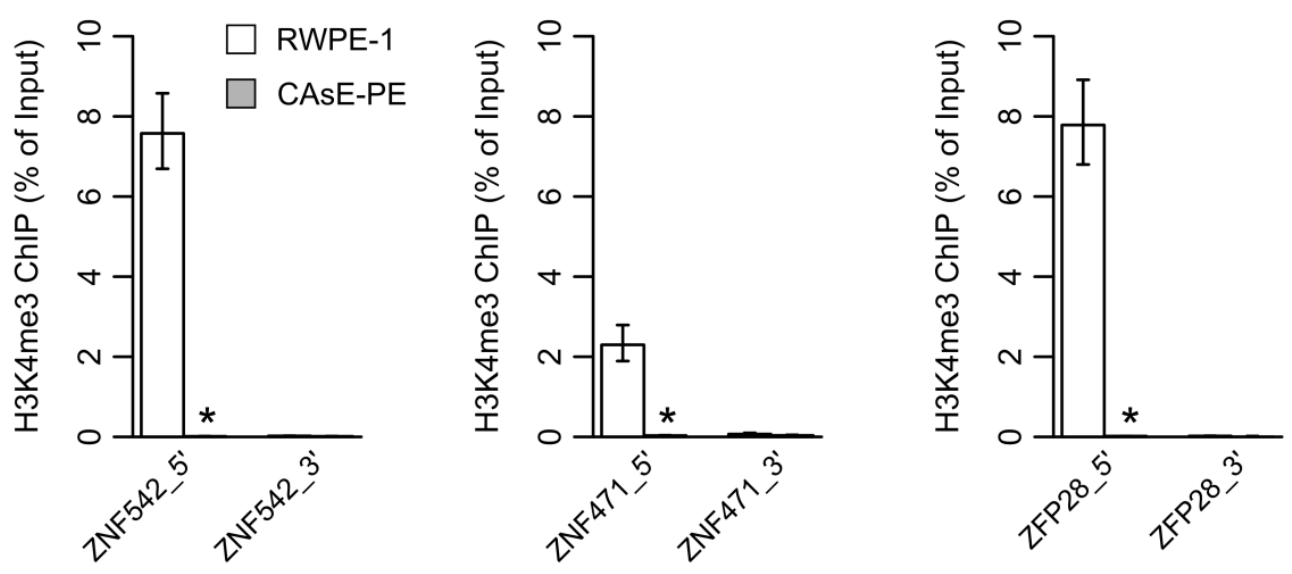

B
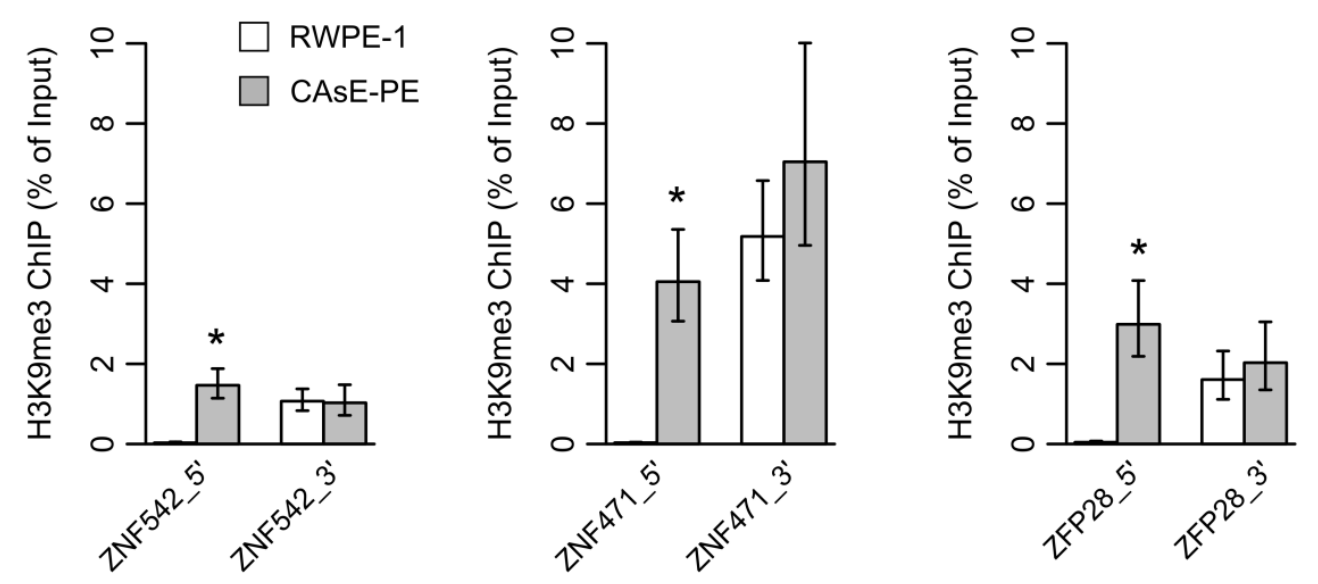

C

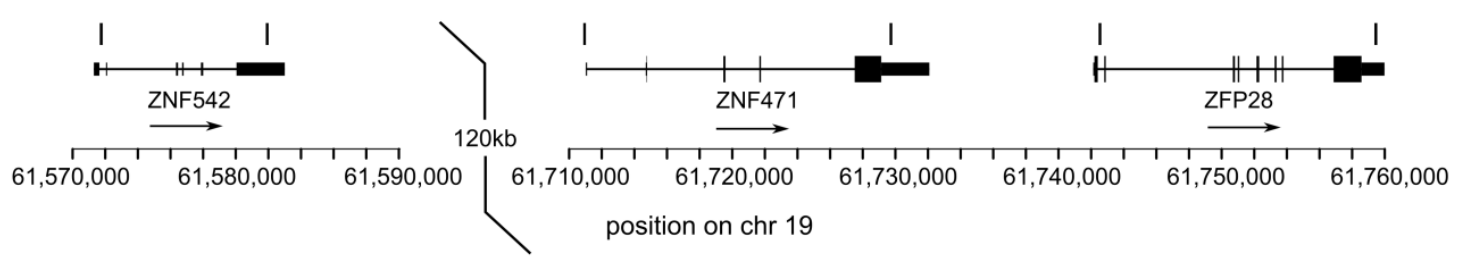

Figure 3.8 ZNF cluster 19.13 ChIPs. ChIPs of 5' and 3' ends of three ZNF genes in cluster 19.13 were quantified by Q-PCR. (A) H3K4me3. (B) H3K9me3. Error bars represent SEM of three experiments $\left({ }^{*} \mathrm{p}=0.05\right.$, Wilcoxon rank sum test). (C) Locations of the ChIP amplicons. 
A
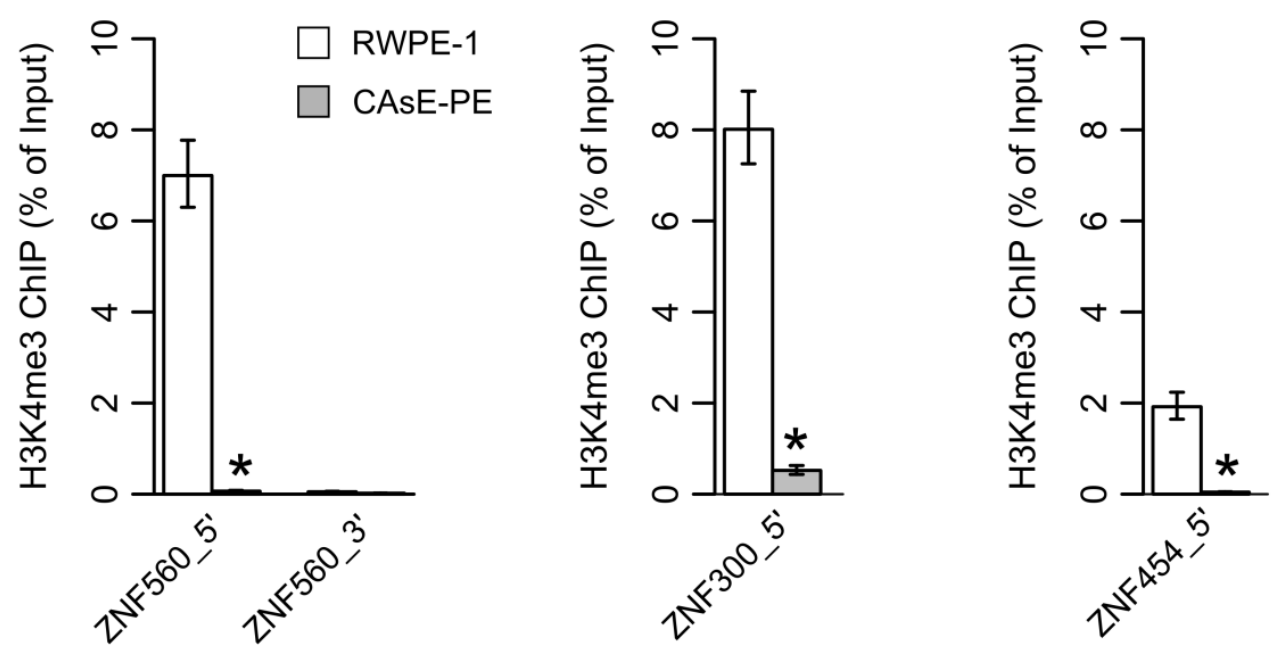

B
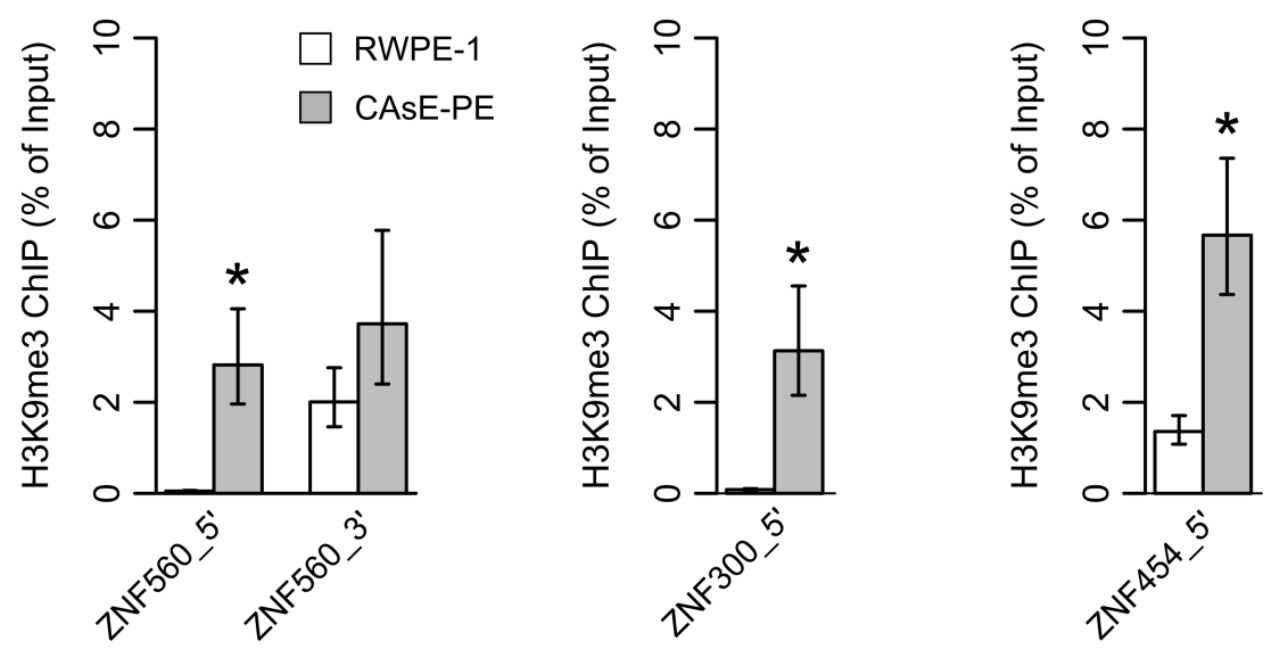

Figure 3.9 ChIPs of 5' and 3' ends of ZNF560 and 5' ends of ZNF300 and ZNF454 were quantified by QRT-PCR. (A) H3K4me3. (B) H3K9me3. Error bars represent the SEM of three experiments $(* \mathrm{p}=0.05$, Wilcoxon rank sum test) 


\section{Discussion}

In this study we have shown that during environmental toxicant-associated malignant transformation of immortalized prostate epithelial cells, roughly a thousand genes are differentially methylated while hundreds more are differentially expressed. Most of the hypermethylated genes have no gene expression change and this is most likely a result of $\mathrm{H} 3 \mathrm{~K} 27 \mathrm{me} 3$ targeted aberrant DNA methylation. In the malignant prostate epithelial cells there was widespread down-regulation of ZNF genes that was mediated by H3K9me3 spreading from the 3' ends of ZNF genes to the ZNF gene promoters. Loss of expression of ZNF genes was associated with a replacement of $\mathrm{H} 3 \mathrm{~K} 4 \mathrm{me} 3$ with $\mathrm{H} 3 \mathrm{~K} 9 \mathrm{me} 3$ and DNA methylation at the ZNF gene promoters. These findings suggest a mechanism in which the boundaries of $\mathrm{H} 3 \mathrm{~K} 9 \mathrm{me} 3$ domains are disrupted, allowing H3K9me3 to spread and direct de novo DNA methylation to the promoters of ZNF genes in particular.

Although H3K27me3 is probably linked to more DNA hypermethylation events overall than H3K9me3 (Figure 3.1B), the H3K27me3 linked aberrant DNA methylation events are not associated with gene expression changes. In terms of phenotypic change, this suggests that $\mathrm{H} 3 \mathrm{~K} 9 \mathrm{me} 3$ linked aberrant DNA methylation events have a greater impact on the malignant outcome than $\mathrm{H} 3 \mathrm{~K} 27$ me3 linked aberrant DNA methylation events, which may be a type of epigenetic passenger.

Individual ZNFs and even some clusters of ZNFs have often been found hypermethylated and silenced in several tumor types, suggesting that our findings 
represent a commonly disrupted epigenetic pathway in cancer progression that is not a rare event (Cheng 2010, Oka 2009, Omura 2008, Yamashita 2006, Mori 2011, Lleras 2011, Andresen 2012, Morris 2011, Oka 2009, Mihara 2006). Perhaps the most compelling evidence that silencing of ZNFs in the arsenite-transformed prostate epithelial model is a relevant event are the publicly available TCGA gene expression and DNA methylation datasets from normal prostate and prostate adenocarcinoma tissues. The TCGA data show that DNA methylation-linked silencing of ZNFs is common (Figure 3.10). In addition, large deletions along chromosome 19 are common in several malignancies including cervical cancer, esophageal squamous cell carcinoma and nasopharyngeal carcinoma (Du Plessis 1999, Shao 2001, Tsuda 2002). Together, these data suggest that silencing of ZNFs is an important event in the progression of various cancers and is not an event unique to arsenic-associated malignancies.

The present study identifies 34 down-regulated ZNFs and therefore we can only speculate on what the consequences of such a broad silencing event would be. Several studies have identified individual ZNFs as potential tumor suppressors (including ZNFs $382,569,383,649,540,446,411,418,322)$ that regulate cellular proliferation by inhibiting MAPK signaling and repressing various oncogenes such as MYC, MITF, HMGA2 and CDK6 (Cheng 2010, Huang 2006, Xiang 2006, Cao 2005, Li 2004, Li 2008, Liu 2005a, Liu 2004, Yang 2005). Together, these studies suggest that widespread silencing of ZNFs could lead to increases in MAPK signaling and proliferation. Another interesting possibility arises from recent work which has shown that ZNF genes coevolved with human endogenous retroviruses (HERVs) and that one of their functions is 
to recruit epigenetic machinery to HERV sequences in the genome which leads to HERV silencing by histone and DNA methylation (Guallar 2012, Rowe and D. Trono 2011, Thomas and S. Schneider 2011, Rowe 2013). This suggests that one possible effect of widespread ZNF gene silencing could be hypomethylation and de-repression of HERVs, events that are commonly found in tumors (reviewed in ref (Romanish 2010)).

Finally, results from the ChIP assays indicated that in malignant cells, H3K9me3 had spread into previously unoccupied genomic regions. One potential mechanism underlying aberrant $\mathrm{H} 3 \mathrm{~K} 9 \mathrm{me} 3$ spreading in malignant transformation involves the CTCF insulator elements which are found at the boundaries between inactive and active genomic regions. When in the right genomic positions, CTCF elements may help contain heterochromatic regions, preventing their spread into active genomic regions. Therefore, loss of CTCF insulator elements is one possible explanation of how $\mathrm{H} 3 \mathrm{~K} 9$ me 3 could spread from the 3'UTR of ZNF genes to the promoter regions, but future studies will have to show whether this hypothesis holds any merit. 


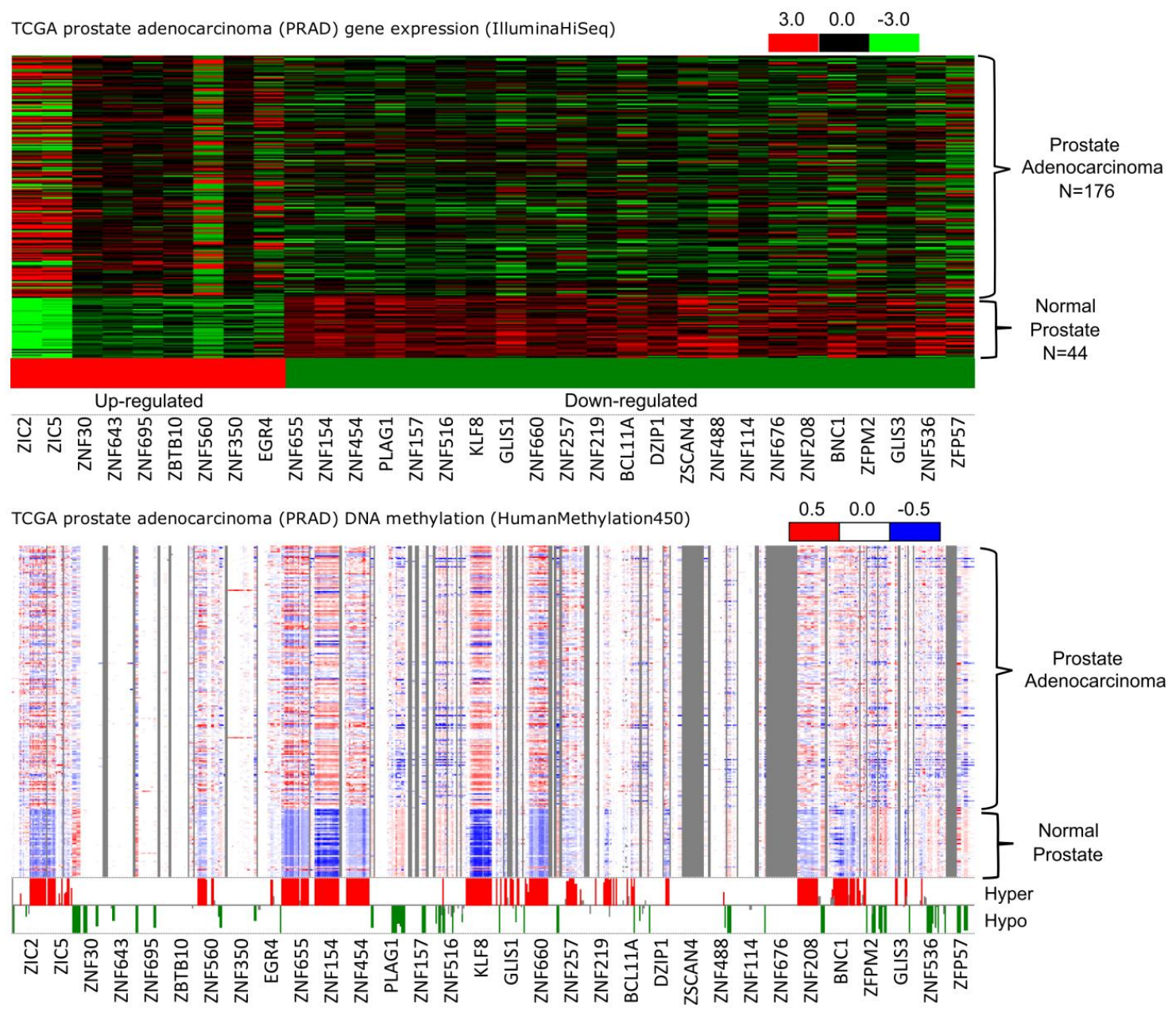

Figure 3.10 TCGA prostate adenocarcinoma datasets visualized using the UCSC Cancer Browser (Goldman 2013). (Top) RNA seq dataset ID TCGA_PRAD_exp_HiSeqV2. 32 differentially expressed $\mathrm{C} 2 \mathrm{H} 2-\mathrm{ZNFs}$ with fold change $\geq 2$ and adjusted p-value $\leq 0.05$. 23 of the 32 are significantly down-regulated. (Bottom) Illumina Infinium HumanMethylation450 dataset ID TCGA_PRAD_hMethyl450. Methylation status of the 32 differentially expressed ZNF genes shows that hypermethylation of ZNFs is common across many prostate adenocarcinoma samples. 


\section{CHAPTER 4: CURRENT PERSPECTIVES AND FUTURE DIRECTIONS}

\section{Current Perspectives on Arsenical-Associated Epigenetic Dysfunction}

After a review of the literature and the completion of the present studies, it is clear that chronic arsenic exposure of immortalized cells further alters covalent histone modifications and DNA methylation leading to an epigenetic landscape that is reminiscent of cancer. The logical question that follows is "how?" It is possible that arsenic directly targets some epigenetic machinery, since it is known to bind a variety of proteins. However, based on the epigenomic similarities between arsenic-transformed cells and human tumor biopsies, a more likely possibility is that arsenic acts upstream of the epigenetic machinery by inducing a state of energy deregulation and oxidative stress which lead to altered signaling pathways and the downstream aberrant epigenome.

The fact that chronic arsenic exposure can induce epigenetic remodeling makes it appear to be a type of epimutagen, an agent whose exposure induces stable and heritable changes to the epigenetic state. When put into perspective, the effects of arsenic may be shared by many other environmental agents and carcinogens. Practically all cancers share an epigenetic landscape with global hypomethylation and aberrant gene promoter hypermethylation. In other words, most agents that are known to initiate or promote cancer somehow lead to a similar end result, an aberrant epigenome. This may indicate that arsenic and many other carcinogenic agents are affecting the same critical upstream processes, leading to an aberrant epigenome. Indeed, several other studies have shown that environmental toxicants and metals besides arsenic, such as cadmium, chromium, nickel, and air pollution or benzene also produce epigenetic changes (Ali 2011, Baccarelli 
and V. Bollati 2009, Zhou 2009). Based on the samples discussed in chapters 2 and 3, it seems unlikely that arsenic-transformed cells harbor an arsenic specific pattern of epigenetic dysfunction since there were no aberrant DNA methylation events that occurred in all the arsenical transformed cell lines that did not occur in the prostate cancer cell lines or bladder tumor biopsies. This evidence suggests that arsenic may not have its own unique mechanism to produce epigenetic dysfunction. Rather, it alters the same upstream pathways which are altered by other carcinogens.

In conclusion, long-term arsenic exposure is linked to aberrant epigenetic remodeling in many human tissues. An arsenic specific pattern of epigenetic remodeling may exist, although it would likely be overshadowed by the widespread epigenomic changes that occur generally in malignant cells. The fact that epigenetic mechanisms are reversible offers hope in the treatment of arsenical associated chronic diseases. Indeed, many ongoing clinical trials are studying the effects of chemicals which alter epigenetic states, including arsenicals themselves. Diminishing the effects of arsenic by using antioxidants may be a viable option to prevent arsenical induced diseases, but the ideal solution is to prevent human exposure to arsenic. It will be especially important to determine a safe exposure level for pregnant mothers, since in utero development is when normal epigenetic patterns are established and when humans are most sensitive to arsenic.

\section{Critical Processes Altered by Arsenical Exposure}

Diverse diseases with potentially common targets 
Epidemiological data has associated environmental arsenical exposure with a plethora of toxicities including cancer, neurotoxicity, cardiovascular disease, developmental abnormalities, and lung disease (Smith 1998, Chen 2007a, Vahidnia 2007, Vahter 2008, Grandjean and K. Murata 2007, Smith 2006, Smith 2011) and decades of research have discovered literally hundreds of distinct molecular targets and pathways altered as a result of arsenic exposure. If it were possible to sift through all the distinct molecular targets of arsenical exposure present in the expansive literature and filter out all the tissue-type specific targets, we might find that arsenic always affects a few fundamental processes that are present in all cell types. If this hypothesis were correct it would help to explain how arsenic causes so many distinct diseases and would imply that environmental arsenic exposure disrupts a few key cellular processes as its primary mechanism leading to diverse diseases.

Some potential upstream factors altered by arsenic exposure which may underlie diverse toxicities and lead to epigenetic remodeling are mitochondrial function and reactive oxygen species. One feasible viewpoint derived from a consolidation of decades of research on arsenic is that environmentally relevant doses of arsenic perturb oxidative phosphorylation and produce oxidative stress which together, underlies epigenetic remodeling in practically all arsenic-associated chronic diseases. This is supported by research which has shown that energy deregulation and oxidative stress are associated with practically all chronic diseases independently of arsenic exposure.

\section{Energy deregulation, mitochondrial dysfunction and ROS}


Arsenic induces morphologic changes in mitochondria and a rapid decline of mitochondrial membrane potential (Jomova 2011). Arsenic induced ROS and arsenic itself can bind and inhibit pyruvate dehydrogenase leading to a reduction of both citric acid cycle activity and production of ATP (Bergquist 2009). It has been shown that in order for arsenic to induce chromosomal damage, a cell must retain mitochondrial activity (Liu 2005b), which suggests the mitochondria are the main source of ROS which induce DNA damage. The mitochondria also produce key intermediates and cofactors which are required for appropriate methylation of DNA and covalent histone modifications. When enough mitochondria are altered by arsenic so that these cofactors are put out of balance, epigenetic remodeling and dysfunction in the nucleus would seem a logical outcome (Wallace and W. Fan 2010).

There is evidence which suggests that oxidative damage to DNA disrupts the maintenance of normal DNA methylation patterns (Weitzman 1994, Turk 1995). ROS have even been linked to global DNA hypomethylation in vivo (Bhusari 2010). A new ROS related hypothesis suggests that oxidative stress is an important regulator in the conversion of 5-methylcytosine to 5-hydroxymethylcytosine (5hmc) (Chia 2011). 5hmc has been proposed as a starting point for both active and passive demethylation and these mechanisms could contribute to the global hypomethylation associated with arsenic exposure. ROS are also known to act as second messengers in signaling pathways which can converge on chromatin to induce epigenetic remodeling of specific genes. This has been demonstrated in hepatocellular carcinoma cells treated with hydrogen peroxide, which induced expression of DNA binding proteins that recruited DNMT1 and lead to 
hypermethylation of a specific gene promoter (Lim 2008). A similar scenario seems plausible for targets of arsenic induced DNA methylation. Finally, the oxidative state of a cell is thought to play an important role in establishing the appropriate epigenetic patterning during development (Hitchler and F. E. Domann 2007). Arsenicals, by altering cellular ROS levels, may affect cofactor availability to epigenetic modifying enzymes leading to epigenetic dysfunction (Hitchler and F. E. Domann 2007).

Data collected in the present studies also supports the hypothesis that arsenic disrupts mitochondrial energy production and produces oxidative stress as a primary mechanism leading to epigenetic dysfunction. Besides the broad down-regulation of ZNF genes that was detailed in chapter 3, the gene expression profile of CAsE-PE included many changes known to be relevant in prostate cancer progression and was suggestive of an arsenite-induced deregulation of energy metabolism. For example, upregulation of HMOX1, S100P and LOX and down-regulation of SPARC and UCHL1 have been associated with cancer progression (Ummanni 2011, Said 2009, Wong 2008). LOX is induced under hypoxic conditions and plays a role in metastasis (Erler 2006, Elguero 2012). HMOX1 is an important pro-survival stress response gene and participates in the cellular antioxidant response which is induced downstream of mitochondrial defects (Blann 2011, Elguero 2012, Li 2011). Interestingly, CAsE-PE cells also had a significant down-regulation of TGFB2 (Figure 3.3) which has been correlated with the $\mathrm{CpG}$ island methylator phenotype and isocitrate dehydrogenase (IDH) mutations. IDH mutations lead to inhibition of Jumonji histone demethylases and global increases of H3K9me3 (Lu 2012, Duncan 2012, Turcan 2012, Liu 2012). In the course 
of the present studies we observed that during arsenite exposure, RWPE-1 cells secrete excess lactate suggesting that metabolic pathways have been altered as a result of the arsenic exposure (Zhao 2013). In the beas-2b cell line this effect was further characterized which showed that glycolysis pathways were significantly up-regulated as a result of arsenic exposure (Zhao 2013). Taken together, these data suggest that one possible pathway between arsenite exposure and epigenetic dysfunction could be disruption of mitochondrial energy production pathways which leads to buildup of TCA cycle byproducts and ROS, followed by inhibition of epigenetic modifier enzymes such as Jumonji histone demethylases.

\section{Future Directions}

The studies described in chapters 2 and 3 have identified several regions where aberrant DNA methylation is linked to $\mathrm{H} 3 \mathrm{~K} 27 \mathrm{me} 3$ or H3K9me3. For H3K9me3, we have shown that after malignant transformation, it spread from the 3' ends of ZNF genes to the 5' ends. This information implies that there are established epigenetic boundaries in RWPE-1 cells within several of the ZNF genes' bodies which maintain H3K9me3 at the 3 ' ends of the genes while keeping the promoter region free of this mark. In order to understand the potential mechanism which drives $\mathrm{H} 3 \mathrm{~K} 9 \mathrm{me} 3$ spreading during arsenical exposure and the effects of widespread ZNF genes silencing, the following experiments are proposed:

ChIPs to identify and characterize H3K9me3 boundaries within ZNF genes

H3K9me3 ChIP-seq for PrEC, RWPE-1 and CAsE-PE could confidently identify the locations of the $\mathrm{H} 3 \mathrm{~K} 9 \mathrm{me} 3$ boundaries that should exist within several $\mathrm{ZNF}$ gene 
bodies. This information would allow us to perform targeted ChIP assays in RWPE-1 cells for candidate enzymes that may participate in $\mathrm{H} 3 \mathrm{~K} 9 \mathrm{me} 3$ boundary establishment or maintenance. For example, Jumonji histone demethylase proteins might participate in H3K9me3 boundary maintenance by actively demethylating H3K9me3. Enrichment of Jumonji enzymes at the $\mathrm{H} 3 \mathrm{~K} 9 \mathrm{me} 3$ boundary would support their potential role as participants in $\mathrm{H} 3 \mathrm{~K} 9 \mathrm{me} 3$ boundary maintenance and would therefore identify them as potential targets during arsenical-induced malignant transformation. Other proposed ChIP assays at the H3K9me3 boundary include: CTCF, SETDB1, DNTM3B, DNMT1, TET1 and KAP1. Identifying each of these enzymes at the H3K9me3 boundary within ZNF genes would expand our list of potential enzymes altered during cancer progression that lead to H3K9me3 spreading and DNA hypermethylation.

\section{Challenging the H3K9me3 boundaries to identify probable targets}

Once the $\mathrm{H} 3 \mathrm{~K} 9 \mathrm{me} 3$ boundaries and the enzymes present at these boundaries have been characterized, experiments should be carried out which challenge the boundary and subsequently measure the effects on $\mathrm{H} 3 \mathrm{~K} 9 \mathrm{me} 3$ spreading. For example, knocking down Jumonji demethylases using siRNA and then performing targeted H3K9me3 ChIPs would show whether disrupting Jumonji demethylases causes the H3K9me3 boundary to shift. Another approach would be to expose RWPE-1 cells to high levels of cellpermeable fumarate. Fumarate is a TCA cycle intermediate that is present at high levels in tumors that have fumarate hydratase mutations. High levels of fumarate have been shown to inhibit histone demethylases, an event which led to global increases in histone methylation (Xiao 2012). If exposing RWPE-1 cells to fumarate leads to spreading of 
H3K9me3 within ZNFs, it would suggest that Jumonji histone demethylases are important regulators of the $\mathrm{H} 3 \mathrm{~K} 9 \mathrm{me} 3$ boundaries within $\mathrm{ZNF}$ genes and that arsenic exposure might interfere with TCA cycle enzymes. Direct inhibition of TCA cycle enzymes with siRNA followed by targeted ChIP assays would take the hypothesis one step further if it showed that disrupting the TCA cycle produced a similar H3K9me3 profile as long term arsenic exposure. Investigating potential outcomes of widespread ZNF gene silencing

Recent studies have shown that one major function of ZNF genes is to silence endogenous retroviruses by recruiting repressive epigenetic machinery (Guallar 2012, Rowe and D. Trono 2011, Thomas and S. Schneider 2011, Rowe 2013). As a first line of experiments to address the phenotypic effects of widespread ZNF gene silencing, the expression levels of HERVs between RWPE-1 and CAsE-PE would be measured by QRT-PCR using previously designed primers for HERVs that are overexpressed in prostate cancer (Ishida 2008). If these preliminary studies show significant HERV expression differences between RWPE-1 and CAsE-PE, it would justify complete RNA sequencing. The repetitive sequences in the RNA-seq data could be sorted into their respective families using the RepBase database to show which types of repetitive elements are differentially expressed in CAsE-PE relative to RWPE-1.

Replicating the significant down-regulation of $34 \mathrm{ZNF}$ genes presents technical challenges, but one possibility is to design siRNA molecules that target conserved domains within the group of down-regulated ZNFs. For instance, a single siRNA molecule targeting the KRAB domain has the potential to knock down many ZNF genes 
since 26 of the 34 down-regulated ZNFs in CAsE-PE were KRAB-ZNFs. Once siRNA mediated down-regulation of multiple ZNFs is achieved in RWPE-1 cells, proliferation, colony formation potential and metastatic potential would be assessed. 
APPENDIX A: SUPPLEMENTAL INFORMATION FOR CHAPTER 2 


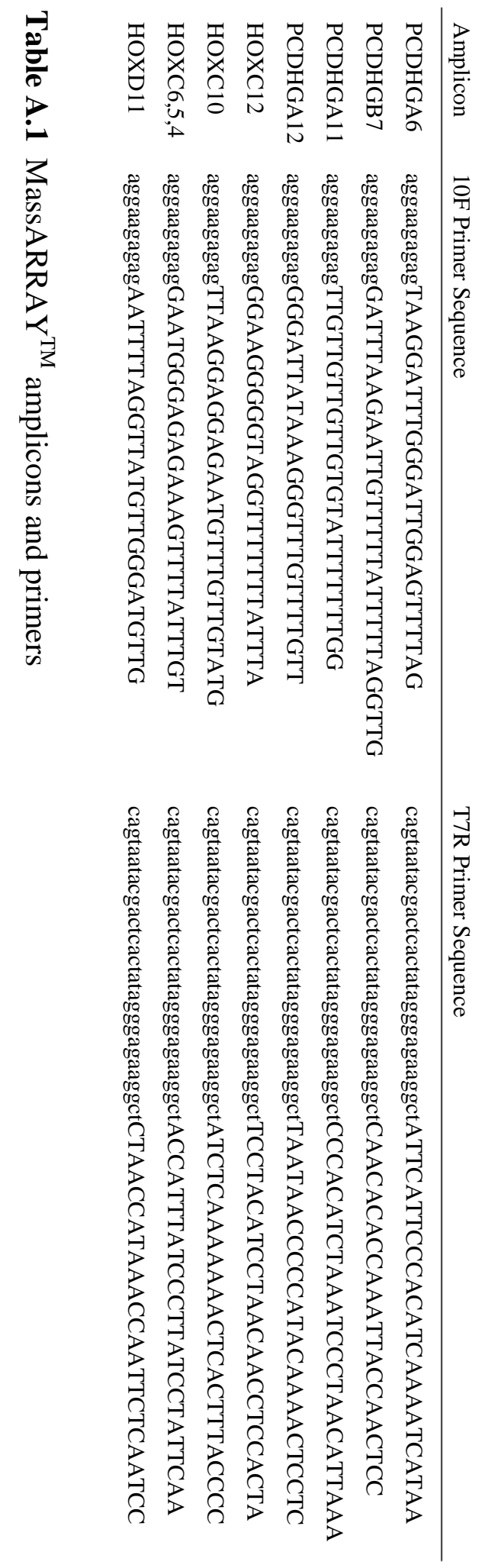


A

$\underline{\text { Hypermethylated Probes (34667) }}$
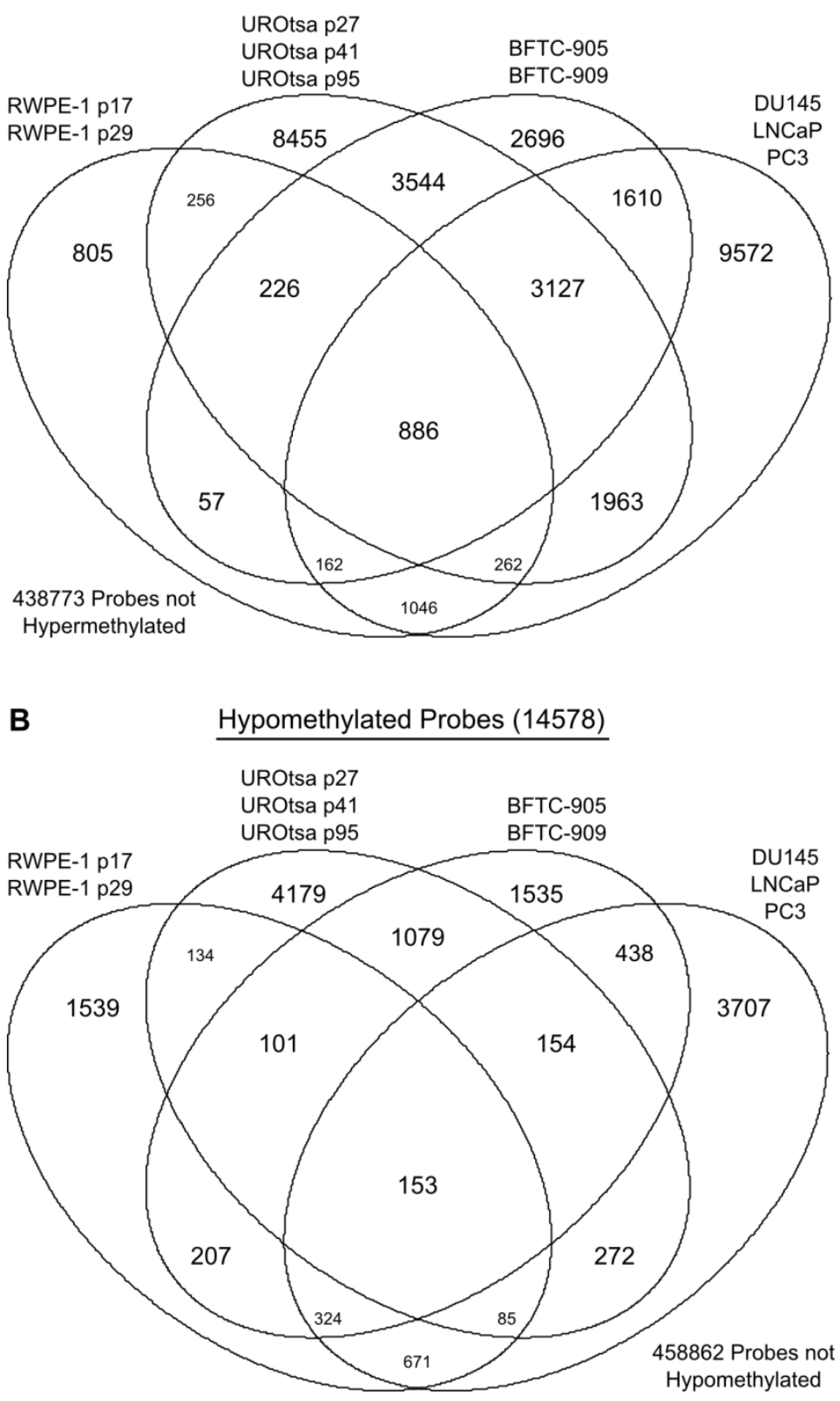

Figure A.1 Venn Diagrams showing the numbers of significant probes compared to respective normal that are shared between the different groups of cancer cell lines and immortal cell lines. (A) Overlap of hypermethylated probes between groups. (B) Overlap of hypomethylated probes between groups. 


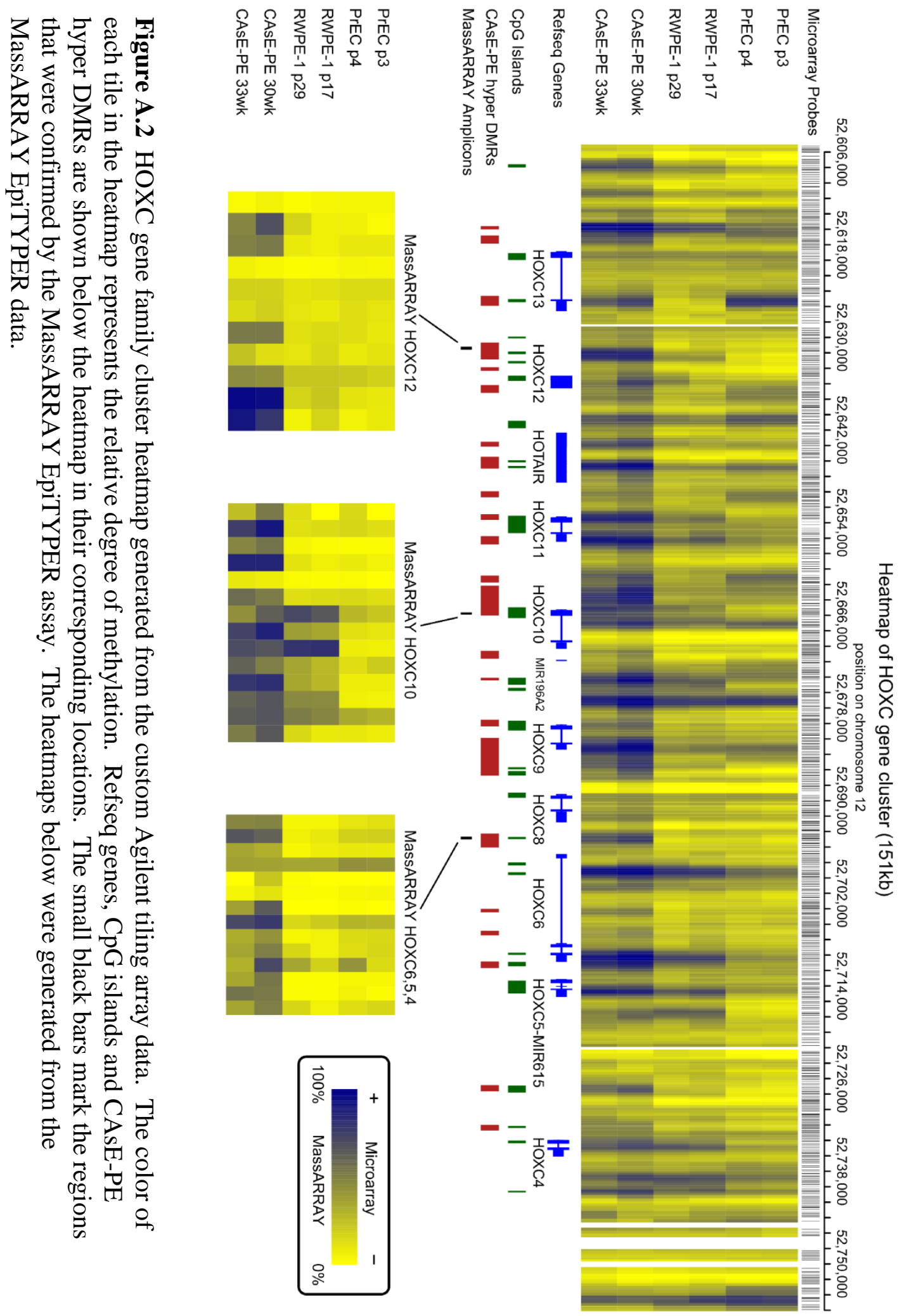



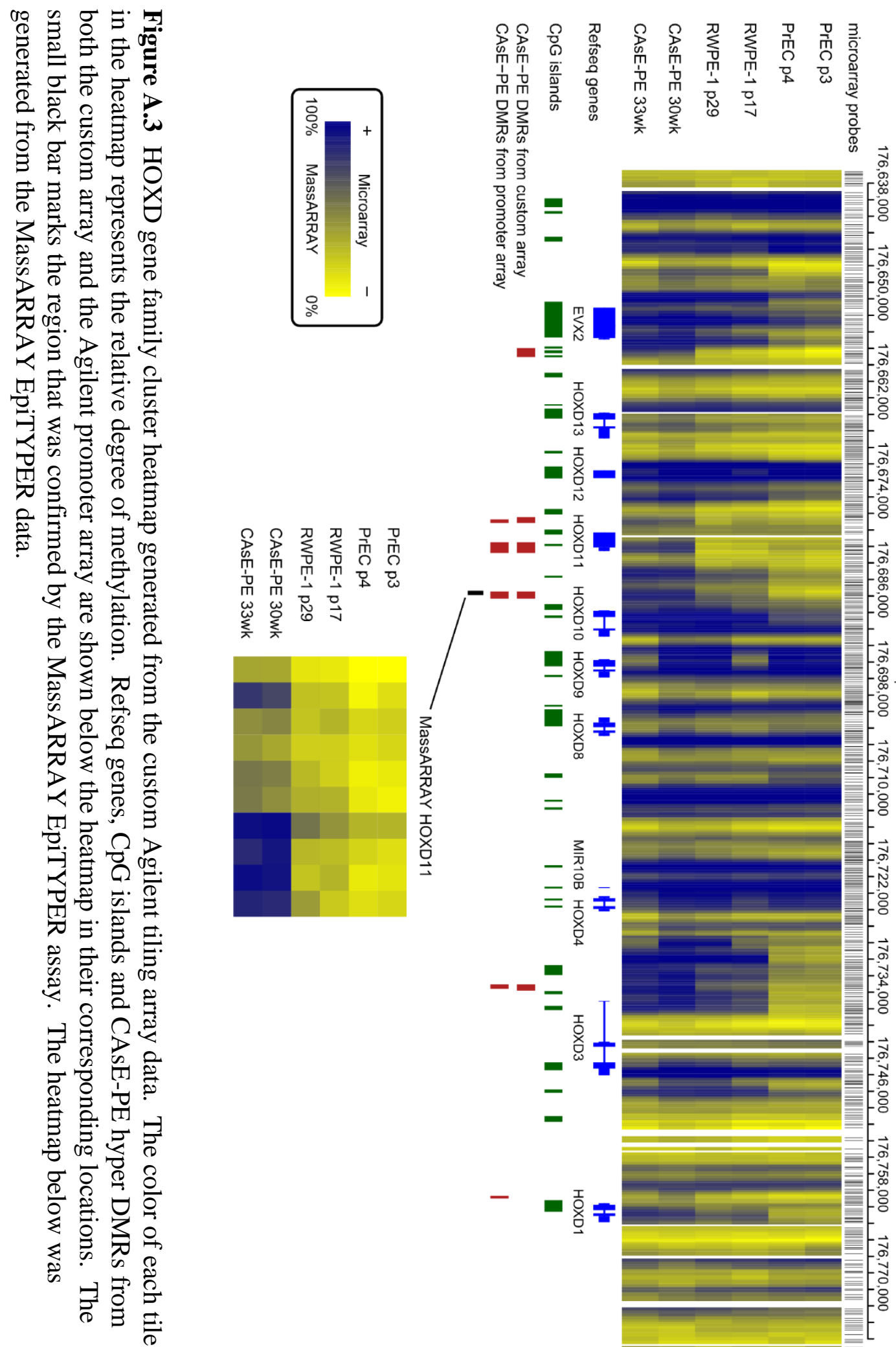


\section{APPENDIX B: SUPPLEMENTAL INFORMATION FOR CHAPTER 3}

\begin{tabular}{|c|c|c|c|c|c|c|}
\hline Biol. Process & $\mathrm{p}$-value & $\begin{array}{l}\text { Odds } \\
\text { Ratio }\end{array}$ & $\begin{array}{l}\text { Exp. } \\
\text { Count }\end{array}$ & Count & Size & Term \\
\hline$\overline{\text { GO:0032501 }}$ & $2.44 \mathrm{E}-22$ & 2.37 & 181.82 & 289 & 3714 & multicellular organismal process \\
\hline GO:0032502 & $7.30 \mathrm{E}-20$ & 2.33 & 129.63 & 223 & 2602 & developmental process \\
\hline GO:0045944 & $7.65 \mathrm{E}-19$ & 3.87 & 23.82 & 74 & 430 & $\begin{array}{l}\text { positive regulation of transcription from } \\
\text { RNA polymerase II promoter }\end{array}$ \\
\hline GO:0010628 & $1.21 \mathrm{E}-17$ & 2.99 & 40.72 & 100 & 735 & positive regulation of gene expression \\
\hline GO:0032774 & $2.33 \mathrm{E}-17$ & 2.13 & 132.36 & 222 & 2389 & RNA biosynthetic process \\
\hline GO:0051254 & $1.51 \mathrm{E}-16$ & 2.91 & 40.28 & 97 & 727 & $\begin{array}{l}\text { positive regulation of RNA metabolic } \\
\text { process }\end{array}$ \\
\hline GO:0010557 & $3.99 \mathrm{E}-16$ & 2.78 & 44.16 & 102 & 797 & $\begin{array}{l}\text { positive regulation of macromolecule } \\
\text { biosynthetic process }\end{array}$ \\
\hline GO:0051173 & $5.13 \mathrm{E}-16$ & 2.74 & 45.65 & 104 & 824 & $\begin{array}{l}\text { positive regulation of nitrogen compound } \\
\text { metabolic process }\end{array}$ \\
\hline GO:0031328 & $6.22 \mathrm{E}-16$ & 2.68 & 48.48 & 108 & 875 & $\begin{array}{l}\text { positive regulation of cellular } \\
\text { biosynthetic process }\end{array}$ \\
\hline GO:0007417 & $6.28 \mathrm{E}-15$ & 3.30 & 25.55 & 70 & 469 & central nervous system development \\
\hline
\end{tabular}

Odds Exp.

\begin{tabular}{|l|r|r|r|r|r|l|l|} 
Mol. Func. & \multicolumn{1}{l}{ p-value } & \multicolumn{1}{l}{ Ratio } & \multicolumn{1}{l}{ Count } & \multicolumn{1}{l}{ Count } & \multicolumn{1}{l}{ Size } & Term \\
\hline GO:0043565 & $2.40 \mathrm{E}-42$ & 5.93 & 28.27 & 117 & 506 & sequence-specific DNA binding \\
\hline GO:0003700 & $2.36 \mathrm{E}-32$ & 4.34 & 36.99 & 120 & 688 & $\begin{array}{l}\text { sequence-specific DNA binding } \\
\text { transcription factor activity }\end{array}$ \\
\hline GO:0001067 & $4.04 \mathrm{E}-12$ & 4.21 & 11.62 & 40 & 208 & regulatory region nucleic acid binding \\
\hline GO:0070888 & $1.62 \mathrm{E}-08$ & 19.04 & 1.06 & 10 & 19 & E-box binding \\
\hline GO:0003705 & $3.38 \mathrm{E}-08$ & 5.98 & 3.91 & 18 & 70 & $\begin{array}{l}\text { sequence-specific distal enhancer binding } \\
\text { RNA polymerase II transcription factor } \\
\text { activity }\end{array}$ \\
\hline GO:0001077 & $1.37 \mathrm{E}-07$ & 11.10 & 1.56 & 11 & 28 & $\begin{array}{l}\text { RNA polymerase II core promoter } \\
\text { proximal region sequence-specific DNA } \\
\text { binding transcription factor activity } \\
\text { involved in positive regulation of } \\
\text { transcription }\end{array}$ \\
\hline GO:0000981 & $2.13 \mathrm{E}-07$ & 7.04 & 2.68 & 14 & 49 & $\begin{array}{l}\text { sequence-specific DNA binding RNA } \\
\text { polymerase II transcription factor activity }\end{array}$ \\
\hline GO:0003682 & $5.31 \mathrm{E}-07$ & 3.27 & 9.89 & 28 & 177 & chromatin binding \\
\hline GO:0008134 & $6.88 \mathrm{E}-07$ & 2.62 & 16.76 & 39 & 300 & transcription factor binding \\
\hline GO:0000977 & $2.03 \mathrm{E}-06$ & 10.99 & 1.29 & 9 & 23 & $\begin{array}{l}\text { RNA polymerase II regulatory region } \\
\text { sequence-specific DNA binding }\end{array}$ \\
\hline
\end{tabular}

Table B.1 Top ten biological processes and molecular functions enriched within the hypermethylated gene dataset. Gene ontology statistical tests were performed using the GOStats package in R (Falcon and R. Gentleman 2007). 


\begin{tabular}{|c|c|c|c|}
\hline \multicolumn{4}{|l|}{ ChIPs Primers } \\
\hline Amplicon name & Forward & Reverse & $\begin{array}{l}\text { UPL } \\
\text { Probe }\end{array}$ \\
\hline ZNF560_5' & taccctgggtcgattgtgac & tcgtgtggactagtgggttg & 87 \\
\hline ZNF560_3'UTR & gctttctcacattccttacattga & tgtttcctcaagcctaactgaa & 2 \\
\hline ZNF542_5' & agggatccgttcaggtcag & tcacgcgagcattcttgtaa & 10 \\
\hline ZNF542_3'UTR & cctgagctcaagcagtccat & aggcacaatggctcatgtct & 30 \\
\hline ZFP28_5' & aactgtgeccetggtettt & tctgaatcagttgagcttccaa & 22 \\
\hline ZFP28_3'UTR & tgaaatttaagttttggtgtctgtaaa & gcacaatcaaggtgtaaatcactg & 41 \\
\hline ZNF471_5' & tgctctaaggtccctctcactc & ggcctagtgttgaggggatt & 66 \\
\hline ZNF471_3'UTR & cagaaccgcttactccettg & ctcagtgggcatgggaac & 41 \\
\hline ZNF454_5' & ctctgggaagtggagtctgg & gccgaattcccacaagtct & 66 \\
\hline ZNF300_5' & ccacagactcacccttcacc & ggtggttttgggacctgata & 33 \\
\hline PHOX2B & cgctctaagcctctctcgaa & ccatggccgatcagaaatac & 5 \\
\hline $\mathrm{HOXC12}$ & taggttcceggtgggtct & gctgtcgacaaccactagca & 15 \\
\hline VSX1 & aggggcttccgataaggata & ggggagatttgggtcttcc & 75 \\
\hline GAPDH & cccgtccttgactccetagt & gtgatcggtgctggttcc & 44 \\
\hline \multicolumn{4}{|c|}{ Expression Primers } \\
\hline Gene & Forward & Reverse & $\begin{array}{l}\text { UPL } \\
\text { Probe }\end{array}$ \\
\hline ZFP28 & tccccaggagagaaacaaga & catccccaaatgtcaccaa & 75 \\
\hline LOX & ggatacggcactggctactt & gacgcctggatgtagtaggg & 14 \\
\hline ZNF300 & cttgtcctgggactgaggaa & cttccaaaaggccagatgaa & 25 \\
\hline ZNF454 & accectggaggcttctgt & attgatccaattcttcttcagga & 13 \\
\hline ACSL1 & ggagtgggctgcagtgac & gggcttgcattgtcetgt & 70 \\
\hline HMOX1 & ggcagagggtgatagaagagg & agctcctgcaactcctcaaa & 15 \\
\hline $\mathrm{CFH}$ & tccagaagtgaactgctcaatg & ttgtgagaattgggaatctgag & 10 \\
\hline SPARC & ttccctgtacactggcagttc & aatgctccatggggatga & 36 \\
\hline FGF5 & actggccaatttttgaaataagat & ctgagactttcaaatagggcaga & 25 \\
\hline TGFB2 & cettcttccectccgaaac & agagcacctgggactgtctg & 44 \\
\hline ZNF542 & aagagataagaggcccattgc & cacctggcacatcttttcc & 14 \\
\hline ZNF560 & aagaagagttgagaaccttgcag & tgctgaaacactggtttgatg & 61 \\
\hline S100P & gggagctcaaggtgctgat & caatttatccacggcatcct & 4 \\
\hline ZNF788 & agttggaagctcagacatgga & ccactcgtctggggtgaa & 76 \\
\hline GAPDH & gagtccactggcgtcttcac & gttcacacccatgacgaaca & 45 \\
\hline
\end{tabular}

Table B.2 Primers used for the experiments described in chapter 3. Corresponding probes from Roche's Universal Probe Library are listed in the final column. 


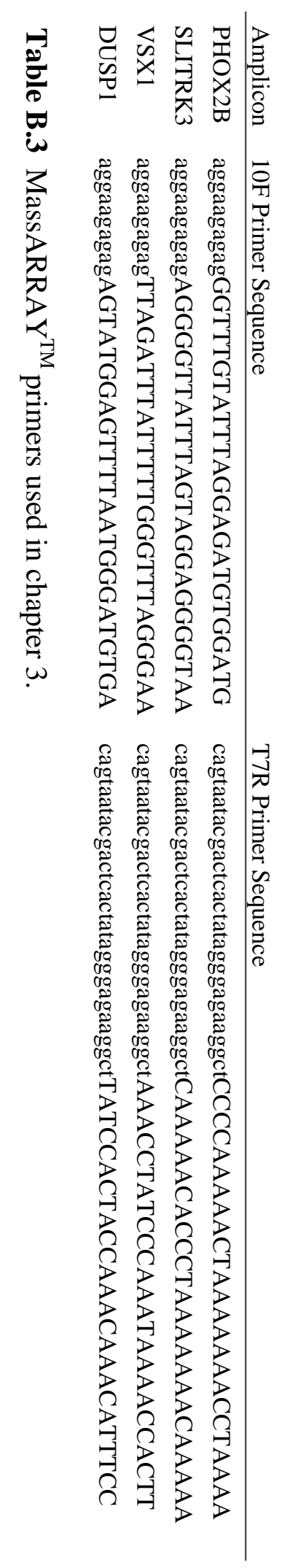




\section{REFERENCES}

Achanzar WE, Brambila EM, Diwan BA, Webber MM, Waalkes MP. 2002a. Inorganic arsenite-induced malignant transformation of human prostate epithelial cells. $J$ Natl Cancer Inst. 24 :1888-1891.

Achanzar WE, Webber MM, Waalkes MP. 2002b. Altered apoptotic gene expression and acquired apoptotic resistance in cadmium-transformed human prostate epithelial cells. Prostate. 3 :236-244. DOI: 10.1002/pros.10106.

Achanzar WE, Diwan BA, Liu J, Quader ST, Webber MM, Waalkes MP. 2001. Cadmium-induced malignant transformation of human prostate epithelial cells. Cancer Res. 2 :455-458.

Ahn RW, Chen F, Chen H, Stern ST, Clogston JD, Patri AK, et al. 2010. A novel nanoparticulate formulation of arsenic trioxide with enhanced therapeutic efficacy in a murine model of breast cancer. Clin Cancer Res. 14 :3607-3617. DOI: 10.1158/1078-0432.CCR-10-0068.

Ai Z, Pan H, Suo T, Lv C, Wang Y, Tong S, et al. 2011. Arsenic oxide targets stem cell marker CD133/prominin-1 in gallbladder carcinoma. Cancer Lett. DOI: 10.1016/j.canlet.2011.06.035.

Ali AH, Kondo K, Namura T, Senba Y, Takizawa H, Nakagawa Y, et al. 2011. Aberrant DNA methylation of some tumor suppressor genes in lung cancers from workers with chromate exposure. Mol Carcinog. 2 :89-99. DOI: 10.1002/mc.20697; 10.1002/mc.20697.

Andresen K, Boberg KM, Vedeld HM, Honne H, Hektoen M, Wadsworth CA, et al. 2012. Novel target genes and a valid biomarker panel identified for cholangiocarcinoma. Epigenetics. 11 :1249-1257. DOI: 10.4161/epi.22191; 10.4161/epi.22191.

Argos M, Kalra T, Rathouz PJ, Chen Y, Pierce B, Parvez F, et al. 2010. Arsenic exposure from drinking water, and all-cause and chronic-disease mortalities in bangladesh (HEALS): A prospective cohort study. Lancet. 9737 :252-258. DOI: 10.1016/S01406736(10)60481-3; 10.1016/S0140-6736(10)60481-3.

Atkinson S, Armstrong L. 2008. Epigenetics in embryonic stem cells: Regulation of pluripotency and differentiation. Cell Tissue Res. 1 :23-29. DOI: 10.1007/s00441007-0536-x.

Augui S, Nora EP, Heard E. 2011. Regulation of X-chromosome inactivation by the Xinactivation centre. Nat Rev Genet. 6 :429-442. DOI: 10.1038/nrg2987. 
Baccarelli A, Bollati V. 2009. Epigenetics and environmental chemicals. Curr Opin Pediatr. 2 :243-251.

Bagnyukova TV, Luzhna LI, Pogribny IP, Lushchak VI. 2007. Oxidative stress and antioxidant defenses in goldfish liver in response to short-term exposure to arsenite. Environ Mol Mutagen. 8 :658-665. DOI: 10.1002/em.20328.

Beckman G, Beckman L, Nordenson I. 1977. Chromosome aberrations in workers exposed to arsenic. Environ Health Perspect. 145-146.

Behn-Krappa A, Holker I, Sandaradura de Silva U, Doerfler W. 1991. Patterns of DNA methylation are indistinguishable in different individuals over a wide range of human DNA sequences. Genomics. $1: 1-7$.

Bello D, Webber MM, Kleinman HK, Wartinger DD, Rhim JS. 1997. Androgen responsive adult human prostatic epithelial cell lines immortalized by human papillomavirus 18. Carcinogenesis. 6 :1215-1223.

Benbrahim-Tallaa L, Waalkes MP. 2008. Inorganic arsenic and human prostate cancer. Environ Health Perspect. 2 :158-164. DOI: 10.1289/ehp.10423.

Benbrahim-Tallaa L, Waterland RA, Styblo M, Achanzar WE, Webber MM, Waalkes MP. 2005a. Molecular events associated with arsenic-induced malignant transformation of human prostatic epithelial cells: Aberrant genomic DNA methylation and K-ras oncogene activation. Toxicol Appl Pharmacol. 3 :288-298. DOI: 10.1016/j.taap.2004.11.017.

Benbrahim-Tallaa L, Webber MM, Waalkes MP. 2005b. Acquisition of androgen independence by human prostate epithelial cells during arsenic-induced malignant transformation. Environ Health Perspect. 9 : 1134-1139.

Bengtsson H, Simpson K, Bullard J, Hansen K. 2008. Aroma.affymetrix: A generic framework in R for analyzing small to very large affymetrix data sets in bounded memory. 745 :.

Bergquist ER, Fischer RJ, Sugden KD, Martin BD. 2009. Inhibition by methylated organo-arsenicals of the respiratory 2-oxo-acid dehydrogenases. J Organomet Chem. 6 :973-980. DOI: 10.1016/j.jorganchem.2008.12.028.

Bernstein BE, Mikkelsen TS, Xie X, Kamal M, Huebert DJ, Cuff J, et al. 2006. A bivalent chromatin structure marks key developmental genes in embryonic stem cells. Cell. 2 :315-326. DOI: 10.1016/j.cell.2006.02.041. 
Bhusari SS, Dobosy JR, Fu V, Almassi N, Oberley T, Jarrard DF. 2010. Superoxide dismutase 1 knockdown induces oxidative stress and DNA methylation loss in the prostate. Epigenetics. 5 :402-409.

Blahnik KR, Dou L, Echipare L, Iyengar S, O'Geen H, Sanchez E, et al. 2011. Characterization of the contradictory chromatin signatures at the 3 ' exons of zinc finger genes. PLoS One. 2 :e17121. DOI: 10.1371/journal.pone.0017121; 10.1371/journal.pone.0017121.

Blann AD, Balakrishnan B, Ryan P, Lip GY. 2011. Increased levels of plasma haemoxygenase-1 in prostate cancer. Prostate Cancer Prostatic Dis. 2 :114-117. DOI: $10.1038 /$ pcan.2010.56; 10.1038/pcan.2010.56.

Bollati V, Baccarelli A. 2010. Environmental epigenetics. Heredity. 1 :105-112. DOI: 10.1038/hdy.2010.2.

Bredfeldt TG, Jagadish B, Eblin KE, Mash EA, Gandolfi AJ. 2006. Monomethylarsonous acid induces transformation of human bladder cells. Toxicol Appl Pharmacol. 1 :6979. DOI: 10.1016/j.taap.2006.04.011.

Brenner AJ, Stampfer MR, Aldaz CM. 1998. Increased p16 expression with first senescence arrest in human mammary epithelial cells and extended growth capacity with p16 inactivation. Oncogene. 2 :199-205. DOI: 10.1038/sj.onc.1201919.

Cantone L, Nordio F, Hou L, Apostoli P, Bonzini M, Tarantini L, et al. 2011. Inhalable metal-rich air particles and histone $\mathrm{H} 3 \mathrm{~K} 4$ dimethylation and $\mathrm{H} 3 \mathrm{~K} 9$ acetylation in a cross-sectional study of steel workers. Environ Health Perspect. 7 :964-969. DOI: 10.1289/ehp.1002955.

Cao L, Wang Z, Zhu C, Zhao Y, Yuan W, Li J, et al. 2005. ZNF383, a novel KRABcontaining zinc finger protein, suppresses MAPK signaling pathway. Biochem Biophys Res Commun. 4 :1050-1059. DOI: 10.1016/j.bbrc.2005.05.193.

Chai CY, Huang YC, Hung WC, Kang WY, Chen WT. 2007. Arsenic salts induced autophagic cell death and hypermethylation of DAPK promoter in SV-40 immortalized human uroepithelial cells. Toxicol Lett. 1 :48-56. DOI: 10.1016/j.toxlet.2007.06.006.

Chanda S, Dasgupta UB, Guhamazumder D, Gupta M, Chaudhuri U, Lahiri S, et al. 2006. DNA hypermethylation of promoter of gene p53 and p16 in arsenic-exposed people with and without malignancy. Toxicol Sci. 2 :431-437. DOI: 10.1093/toxsci/kfj030. 
Chang Q, Pan J, Wang X, Zhang Z, Chen F, Shi X. 2010. Reduced reactive oxygen species-generating capacity contributes to the enhanced cell growth of arsenictransformed epithelial cells. Cancer Res. 12 :5127-5135. DOI: 10.1158/00085472.CAN-10-0007.

Chen CJ, Wang SL, Chiou JM, Tseng CH, Chiou HY, Hsueh YM, et al. 2007a. Arsenic and diabetes and hypertension in human populations: A review. Toxicol Appl Pharmacol. 3 :298-304. DOI: 10.1016/j.taap.2006.12.032.

Chen CJ, Chiou HY, Chiang MH, Lin LJ, Tai TY. 1996. Dose-response relationship between ischemic heart disease mortality and long-term arsenic exposure. Arterioscler Thromb Vasc Biol. 4 :504-510.

Chen CJ, Hsueh YM, Lai MS, Shyu MP, Chen SY, Wu MM, et al. 1995. Increased prevalence of hypertension and long-term arsenic exposure. Hypertension. 1 :53-60.

Chen CJ, Chen CW, Wu MM, Kuo TL. 1992. Cancer potential in liver, lung, bladder and kidney due to ingested inorganic arsenic in drinking water. Br J Cancer. 5 :888-892.

Chen CJ, Wu MM, Lee SS, Wang JD, Cheng SH, Wu HY. 1988. Atherogenicity and carcinogenicity of high-arsenic artesian well water. multiple risk factors and related malignant neoplasms of blackfoot disease. Arteriosclerosis. 5 :452-460.

Chen CL, Chiou HY, Hsu LI, Hsueh YM, Wu MM, Wang YH, et al. 2010. Arsenic in drinking water and risk of urinary tract cancer: A follow-up study from northeastern taiwan. Cancer Epidemiol Biomarkers Prev. 1 :101-110. DOI: 10.1158/10559965.EPI-09-0333.

Chen H, Li S, Liu J, Diwan BA, Barrett JC, Waalkes MP. 2004. Chronic inorganic arsenic exposure induces hepatic global and individual gene hypomethylation: Implications for arsenic hepatocarcinogenesis. Carcinogenesis. 9 :1779-1786. DOI: 10.1093/carcin/bgh161.

Chen H, Liu J, Zhao CQ, Diwan BA, Merrick BA, Waalkes MP. 2001. Association of cmyc overexpression and hyperproliferation with arsenite-induced malignant transformation. Toxicol Appl Pharmacol. 3 :260-268. DOI: 10.1006/taap.2001.9253.

Chen WT, Hung WC, Kang WY, Huang YC, Chai CY. 2007b. Urothelial carcinomas arising in arsenic-contaminated areas are associated with hypermethylation of the gene promoter of the death-associated protein kinase. Histopathology. 6 :785-792. DOI: $10.1111 / \mathrm{j} .1365-2559.2007 .02871 . x$.

Cheng Y, Geng H, Cheng SH, Liang P, Bai Y, Li J, et al. 2010. KRAB zinc finger protein ZNF382 is a proapoptotic tumor suppressor that represses multiple oncogenes and is 
commonly silenced in multiple carcinomas. Cancer Res. 16 :6516-6526. DOI: 10.1158/0008-5472.CAN-09-4566; 10.1158/0008-5472.CAN-09-4566.

Cheng YT, Li YL, Wu JD, Long SB, Tzai TS, Tzeng CC, et al. 1995. Overexpression of MDM-2 mRNA and mutation of the p53 tumor suppressor gene in bladder carcinoma cell lines. Mol Carcinog. 3 :173-181.

Chervona Y, Hall MN, Arita A, Wu F, Sun H, Tseng HC, et al. 2012. Associations between arsenic exposure and global posttranslational histone modifications among adults in bangladesh. Cancer Epidemiol Biomarkers Prev. 12 :2252-2260. DOI: 10.1158/1055-9965.EPI-12-0833; 10.1158/1055-9965.EPI-12-0833.

Chia N, Wang L, Lu X, Senut MC, Brenner C, Ruden DM. 2011. Hypothesis: Environmental regulation of 5-hydroxymethylcytosine by oxidative stress. Epigenetics. 7 :853-856.

Chiou JM, Wang SL, Chen CJ, Deng CR, Lin W, Tai TY. 2005. Arsenic ingestion and increased microvascular disease risk: Observations from the south-western arseniasis-endemic area in taiwan. Int J Epidemiol. 4 :936-943. DOI: 10.1093/ije/dyi108.

Clark SJ. 2007. Action at a distance: Epigenetic silencing of large chromosomal regions in carcinogenesis. Hum Mol Genet. R88-95. DOI: 10.1093/hmg/ddm051.

Coolen MW, Stirzaker C, Song JZ, Statham AL, Kassir Z, Moreno CS, et al. 2010. Consolidation of the cancer genome into domains of repressive chromatin by longrange epigenetic silencing (LRES) reduces transcriptional plasticity. Nat Cell Biol. 3 :235-246. DOI: $10.1038 / \mathrm{ncb} 2023$.

Coppin JF, Qu W, Waalkes MP. 2008. Interplay between cellular methyl metabolism and adaptive efflux during oncogenic transformation from chronic arsenic exposure in human cells. J Biol Chem. 28 :19342-19350. DOI: 10.1074/jbc.M802942200.

Cui X, Wakai T, Shirai Y, Hatakeyama K, Hirano S. 2006. Chronic oral exposure to inorganic arsenate interferes with methylation status of p16INK4a and RASSF1A and induces lung cancer in A/J mice. Toxicol Sci. 2 :372-381. DOI: 10.1093/toxsci/kfj159.

Dallosso AR, Oster B, Greenhough A, Thorsen K, Curry TJ, Owen C, et al. 2012. Longrange epigenetic silencing of chromosome $5 \mathrm{q} 31$ protocadherins is involved in early and late stages of colorectal tumorigenesis through modulation of oncogenic pathways. Oncogene. DOI: 10.1038/onc.2011.609; 10.1038/onc.2011.609. 
Dallosso AR, Hancock AL, Szemes M, Moorwood K, Chilukamarri L, Tsai HH, et al. 2009. Frequent long-range epigenetic silencing of protocadherin gene clusters on chromosome 5q31 in wilms' tumor. PLoS Genet. 11 :e1000745. DOI: 10.1371/journal.pgen.1000745.

Ding W, Hudson LG, Liu KJ. 2005. Inorganic arsenic compounds cause oxidative damage to DNA and protein by inducing ROS and RNS generation in human keratinocytes. Mol Cell Biochem. 1-2 :105-112. DOI: 10.1007/s11010-005-8227-y.

Du Plessis L, Dietzsch E, Van Gele M, Van Roy N, Van Helden P, Parker MI, et al. 1999. Mapping of novel regions of DNA gain and loss by comparative genomic hybridization in esophageal carcinoma in the black and colored populations of south africa. Cancer Res. 8 : 1877-1883.

Duncan CG, Barwick BG, Jin G, Rago C, Kapoor-Vazirani P, Powell DR, et al. 2012. A heterozygous IDH1R132H/WT mutation induces genome-wide alterations in DNA methylation. Genome Res. 12 :2339-2355. DOI: 10.1101/gr.132738.111; 10.1101/gr.132738.111.

Eblin KE, Hau AM, Jensen TJ, Futscher BW, Gandolfi AJ. 2008. The role of reactive oxygen species in arsenite and monomethylarsonous acid-induced signal transduction in human bladder cells: Acute studies. Toxicology. 1 :47-54. DOI: 10.1016/j.tox.2008.05.018.

Eblin KE, Bowen ME, Cromey DW, Bredfeldt TG, Mash EA, Lau SS, et al. 2006. Arsenite and monomethylarsonous acid generate oxidative stress response in human bladder cell culture. Toxicol Appl Pharmacol. 1 :7-14. DOI: 10.1016/j.taap.2006.07.004.

Edwards JR, O'Donnell AH, Rollins RA, Peckham HE, Lee C, Milekic MH, et al. 2010. Chromatin and sequence features that define the fine and gross structure of genomic methylation patterns. Genome Res. 7 :972-980. DOI: 10.1101/gr.101535.109.

Elguero B, Gueron G, Giudice J, Toscani MA, De Luca P, Zalazar F, et al. 2012. Unveiling the association of STAT3 and HO-1 in prostate cancer: Role beyond heme degradation. Neoplasia. 11 :1043-1056.

El-Masri HA, Kenyon EM. 2008. Development of a human physiologically based pharmacokinetic (PBPK) model for inorganic arsenic and its mono- and dimethylated metabolites. J Pharmacokinet Pharmacodyn. 1 :31-68. DOI: 10.1007/s10928-007-9075-z.

Epsztejn-Litman S, Feldman N, Abu-Remaileh M, Shufaro Y, Gerson A, Ueda J, et al. 2008. De novo DNA methylation promoted by G9a prevents reprogramming of 
embryonically silenced genes. Nat Struct Mol Biol. 11 :1176-1183. DOI: 10.1038/nsmb.1476.

Erler JT, Bennewith KL, Nicolau M, Dornhofer N, Kong C, Le QT, et al. 2006. Lysyl oxidase is essential for hypoxia-induced metastasis. Nature. $7088: 1222-1226$. DOI: 10.1038/nature04695.

Falcon S, Gentleman R. 2007. Using GOstats to test gene lists for GO term association. Bioinformatics. 2 :257-258.

Flanagan SV, Johnston RB, Zheng Y. 2012. Arsenic in tube well water in bangladesh: Health and economic impacts and implications for arsenic mitigation. Bull World Health Organ. 11 :839-846. DOI: 10.2471/BLT.11.101253; 10.2471/BLT.11.101253.

Foster FP, Rohe GH. 1896. Reference-book of practical therapeutics, arsenic. In Foster FP, editor. (Eds), D. Appleton and Company: 142.

Frigola J, Song J, Stirzaker C, Hinshelwood RA, Peinado MA, Clark SJ. 2006. Epigenetic remodeling in colorectal cancer results in coordinate gene suppression across an entire chromosome band. Nat Genet. 5 :540-549. DOI: 10.1038/ng1781.

Fu HY, Shen JZ. 2005. Hypermethylation of CpG island of p16 gene and arsenic trioxide induced p16 gene demethylation in multiple myeloma. Zhonghua Nei Ke Za Zhi. 6 :411-414.

Fuks F, Hurd PJ, Deplus R, Kouzarides T. 2003. The DNA methyltransferases associate with HP1 and the SUV39H1 histone methyltransferase. Nucleic Acids Res. 9 :23052312.

Futscher BW, Oshiro MM, Wozniak RJ, Holtan N, Hanigan CL, Duan H, et al. 2002. Role for DNA methylation in the control of cell type specific maspin expression. Nat Genet. 2 :175-179. DOI: 10.1038/ng886.

Garbe JC, Holst CR, Bassett E, Tlsty T, Stampfer MR. 2007. Inactivation of p53 function in cultured human mammary epithelial cells turns the telomere-length dependent senescence barrier from agonescence into crisis. Cell Cycle. 15 :1927-1936.

Gentry PR, McDonald TB, Sullivan DE, Shipp AM, Yager JW, Clewell HJ,3rd. 2010. Analysis of genomic dose-response information on arsenic to inform key events in a mode of action for carcinogenicity. Environ Mol Mutagen. 1 :1-14. DOI: 10.1002/em.20505. 
Goering PL, Aposhian HV, Mass MJ, Cebrian M, Beck BD, Waalkes MP. 1999. The enigma of arsenic carcinogenesis: Role of metabolism. Toxicol Sci. 1 :5-14.

Goldman M, Craft B, Swatloski T, Ellrott K, Cline M, Diekhans M, et al. 2013. The UCSC cancer genomics browser: Update 2013. Nucleic Acids Res. Database issue :D949-54. DOI: 10.1093/nar/gks1008; 10.1093/nar/gks 1008.

Gomez-Rubio P, Meza-Montenegro MM, Cantu-Soto E, Klimecki WT. 2010. Genetic association between intronic variants in AS3MT and arsenic methylation efficiency is focused on a large linkage disequilibrium cluster in chromosome 10. J Appl Toxicol. 3 :260-270. DOI: 10.1002/jat.1492.

Grandjean P, Murata K. 2007. Developmental arsenic neurotoxicity in retrospect. Epidemiology. 1 :25-26. DOI: 10.1097/01.ede.0000249533.77900.74.

Groner AC, Meylan S, Ciuffi A, Zangger N, Ambrosini G, Denervaud N, et al. 2010. KRAB-zinc finger proteins and KAP1 can mediate long-range transcriptional repression through heterochromatin spreading. PLoS Genet. 3 :e1000869. DOI: 10.1371/journal.pgen.1000869; 10.1371/journal.pgen.1000869.

Guallar D, Perez-Palacios R, Climent M, Martinez-Abadia I, Larraga A, Fernandez-Juan M, et al. 2012. Expression of endogenous retroviruses is negatively regulated by the pluripotency marker Rex1/Zfp42. Nucleic Acids Res. 18 :8993-9007. DOI: 10.1093/nar/gks686; 10.1093/nar/gks686.

Hansen KD, Timp W, Bravo HC, Sabunciyan S, Langmead B, McDonald OG, et al. 2011. Increased methylation variation in epigenetic domains across cancer types. Nat Genet. 8 :768-775. DOI: 10.1038/ng.865; 10.1038/ng.865.

Hawkins RD, Hon GC, Lee LK, Ngo Q, Lister R, Pelizzola M, et al. 2010. Distinct epigenomic landscapes of pluripotent and lineage-committed human cells. Cell Stem Cell. 5 :479-491. DOI: 10.1016/j.stem.2010.03.018.

Healy SM, Zakharyan RA, Aposhian HV. 1997. Enzymatic methylation of arsenic compounds: IV. in vitro and in vivo deficiency of the methylation of arsenite and monomethylarsonic acid in the guinea pig. Mutat Res. 3 :229-239.

Hitchler MJ, Domann FE. 2007. An epigenetic perspective on the free radical theory of development. Free Radic Biol Med. 7 :1023-1036. DOI: 10.1016/j.freeradbiomed.2007.06.027.

Horoszewicz JS, Leong SS, Kawinski E, Karr JP, Rosenthal H, Chu TM, et al. 1983. LNCaP model of human prostatic carcinoma. Cancer Res. 4 :1809-1818. 
Hou L, Zhang X, Wang D, Baccarelli A. 2012. Environmental chemical exposures and human epigenetics. Int J Epidemiol. 1 :79-105. DOI: 10.1093/ije/dyr154.

Huang RN, Lee TC. 1996. Cellular uptake of trivalent arsenite and pentavalent arsenate in KB cells cultured in phosphate-free medium. Toxicol Appl Pharmacol. 2 :243249. DOI: 10.1006/taap.1996.0031.

Huang X, Yuan W, Huang W, Bai Y, Deng Y, Zhu C, et al. 2006. ZNF569, a novel KRAB-containing zinc finger protein, suppresses MAPK signaling pathway. Biochem Biophys Res Commun. 3 :621-628. DOI: 10.1016/j.bbrc.2006.05.109.

Huschtscha LI, Noble JR, Neumann AA, Moy EL, Barry P, Melki JR, et al. 1998. Loss of p16INK4 expression by methylation is associated with lifespan extension of human mammary epithelial cells. Cancer Res. 16 :3508-3512.

Hutchinson J. 1887. Arsenic cancer. British Medical Journal. 1406 :1280.

IARC. 2004. Some drinking-water disinfectants and contaminants, including arsenic. IARC Monogr Eval Carcinog Risks Hum. 1-477.

Irizarry RA, Bolstad BM, Collin F, Cope LM, Hobbs B, Speed TP. 2003. Summaries of affymetrix GeneChip probe level data. Nucleic Acids Res. 4 :e15.

Ishida T, Obata Y, Ohara N, Matsushita H, Sato S, Uenaka A, et al. 2008. Identification of the HERV-K gag antigen in prostate cancer by SEREX using autologous patient serum and its immunogenicity. Cancer Immun. 15.

Javierre BM, Rodriguez-Ubreva J, Al-Shahrour F, Corominas M, Grana O, Ciudad L, et al. 2011. Long-range epigenetic silencing associates with deregulation of ikaros targets in colorectal cancer cells. Mol Cancer Res. 8 :1139-1151. DOI: 10.1158/1541-7786.MCR-10-0515.

Jensen TJ, Novak P, Wnek SM, Gandolfi AJ, Futscher BW. 2009a. Arsenicals produce stable progressive changes in DNA methylation patterns that are linked to malignant transformation of immortalized urothelial cells. Toxicol Appl Pharmacol. 2 :221229. DOI: 10.1016/j.taap.2009.08.019.

Jensen TJ, Wozniak RJ, Eblin KE, Wnek SM, Gandolfi AJ, Futscher BW. 2009b. Epigenetic mediated transcriptional activation of WNT5A participates in arsenicalassociated malignant transformation. Toxicol Appl Pharmacol. 1 :39-46. DOI: 10.1016/j.taap.2008.10.013. 
Jensen TJ, Novak P, Eblin KE, Gandolfi AJ, Futscher BW. 2008. Epigenetic remodeling during arsenical-induced malignant transformation. Carcinogenesis. 8 :1500-1508. DOI: 10.1093/carcin/bgn102.

Jiang C, Pugh BF. 2009. Nucleosome positioning and gene regulation: Advances through genomics. Nat Rev Genet. 3 :161-172. DOI: 10.1038/nrg2522.

Jo WJ, Ren X, Chu F, Aleshin M, Wintz H, Burlingame A, et al. 2009. Acetylated H4K16 by MYST1 protects UROtsa cells from arsenic toxicity and is decreased following chronic arsenic exposure. Toxicol Appl Pharmacol. 3 :294-302. DOI: 10.1016/j.taap.2009.08.027.

Jomova K, Jenisova Z, Feszterova M, Baros S, Liska J, Hudecova D, et al. 2011. Arsenic: Toxicity, oxidative stress and human disease. J Appl Toxicol. 2 :95-107. DOI: 10.1002/jat.1649; 10.1002/jat.1649.

Kaighn ME, Narayan KS, Ohnuki Y, Lechner JF, Jones LW. 1979. Establishment and characterization of a human prostatic carcinoma cell line (PC-3). Invest Urol. 1 :1623.

Kapaj S, Peterson H, Liber K, Bhattacharya P. 2006. Human health effects from chronic arsenic poisoning--a review. J Environ Sci Health A Tox Hazard Subst Environ Eng. 10 :2399-2428. DOI: 10.1080/10934520600873571.

Kenyon EM, Klimecki WT, El-Masri H, Conolly RB, Clewell HJ, Beck BD. 2008. How can biologically-based modeling of arsenic kinetics and dynamics inform the risk assessment process? - A workshop review. Toxicol Appl Pharmacol. 3 :359-368. DOI: 10.1016/j.taap.2008.06.023.

Kessel M, Liu SX, Xu A, Santella R, Hei TK. 2002. Arsenic induces oxidative DNA damage in mammalian cells. Mol Cell Biochem. 1-2 :301-308.

Kitchin KT, Ahmad S. 2003. Oxidative stress as a possible mode of action for arsenic carcinogenesis. Toxicol Lett. 1-2 :3-13.

Kligerman AD, Doerr CL, Tennant AH, Harrington-Brock K, Allen JW, Winkfield E, et al. 2003. Methylated trivalent arsenicals as candidate ultimate genotoxic forms of arsenic: Induction of chromosomal mutations but not gene mutations. Environ Mol Mutagen. 3 :192-205. DOI: 10.1002/em.10192.

Kojima C, Ramirez DC, Tokar EJ, Himeno S, Drobna Z, Styblo M, et al. 2009. Requirement of arsenic biomethylation for oxidative DNA damage. J Natl Cancer Inst. 24 :1670-1681. DOI: 10.1093/jnci/djp414. 
Kouzarides T. 2007. Chromatin modifications and their function. Cell. 4 :693-705. DOI: 10.1016/j.cell.2007.02.005.

Lehnertz B, Ueda Y, Derijck AA, Braunschweig U, Perez-Burgos L, Kubicek S, et al. 2003. Suv39h-mediated histone H3 lysine 9 methylation directs DNA methylation to major satellite repeats at pericentric heterochromatin. Curr Biol. 14 :1192-1200.

Li J, Gorospe M, Barnes J, Liu Y. 2003. Tumor promoter arsenite stimulates histone H3 phosphoacetylation of proto-oncogenes c-fos and c-jun chromatin in human diploid fibroblasts. J Biol Chem. 15 :13183-13191. DOI: 10.1074/jbc.M300269200.

Li J, Chen P, Sinogeeva N, Gorospe M, Wersto RP, Chrest FJ, et al. 2002. Arsenic trioxide promotes histone $\mathrm{H} 3$ phosphoacetylation at the chromatin of CASPASE-10 in acute promyelocytic leukemia cells. J Biol Chem. 51 :49504-49510. DOI: 10.1074/jbc.M207836200.

Li Y, Su J, DingZhang X, Zhang J, Yoshimoto M, Liu S, et al. 2011. PTEN deletion and heme oxygenase-1 overexpression cooperate in prostate cancer progression and are associated with adverse clinical outcome. J Pathol. 1 :90-100. DOI: 10.1002/path.2855; 10.1002/path.2855.

Li Y, Yang D, Bai Y, Mo X, Huang W, Yuan W, et al. 2008. ZNF418, a novel human $\mathrm{KRAB} / \mathrm{C} 2 \mathrm{H} 2$ zinc finger protein, suppresses MAPK signaling pathway. Mol Cell Biochem. 1-2 :141-151. DOI: 10.1007/s11010-007-9674-4.

Li Y, Wang Y, Zhang C, Yuan W, Wang J, Zhu C, et al. 2004. ZNF322, a novel human $\mathrm{C} 2 \mathrm{H} 2$ kruppel-like zinc-finger protein, regulates transcriptional activation in MAPK signaling pathways. Biochem Biophys Res Commun. 4 :1383-1392. DOI: 10.1016/j.bbrc.2004.10.183.

Lim SO, Gu JM, Kim MS, Kim HS, Park YN, Park CK, et al. 2008. Epigenetic changes induced by reactive oxygen species in hepatocellular carcinoma: Methylation of the E-cadherin promoter. Gastroenterology. 6 :2128-40, 2140.e1-8. DOI: 10.1053/j.gastro.2008.07.027.

Liu F, Zhu C, Xiao J, Wang Y, Tang W, Yuan W, et al. 2005a. A novel human KRABcontaining zinc-finger gene ZNF446 inhibits transcriptional activities of SRE and AP-1. Biochem Biophys Res Commun. 1 :5-13. DOI: 10.1016/j.bbrc.2005.05.069.

Liu H, Zhu C, Luo J, Wang Y, Li D, Li Y, et al. 2004. ZNF411, a novel KRABcontaining zinc-finger protein, suppresses MAP kinase signaling pathway. Biochem Biophys Res Commun. 1 :45-53. DOI: 10.1016/j.bbrc.2004.05.130. 
Liu SX, Davidson MM, Tang X, Walker WF, Athar M, Ivanov V, et al. 2005b. Mitochondrial damage mediates genotoxicity of arsenic in mammalian cells. Cancer Res. 8 :3236-3242. DOI: 10.1158/0008-5472.CAN-05-0424.

Liu Y, Jiang W, Liu J, Zhao S, Xiong J, Mao Y, et al. 2012. IDH1 mutations inhibit multiple alpha-ketoglutarate-dependent dioxygenase activities in astroglioma. $J$ Neurooncol. 2 :253-260. DOI: 10.1007/s11060-012-0914-4; 10.1007/s11060-0120914-4.

Liu Z, Sanchez MA, Jiang X, Boles E, Landfear SM, Rosen BP. 2006. Mammalian glucose permease GLUT1 facilitates transport of arsenic trioxide and methylarsonous acid. Biochem Biophys Res Commun. 2 :424-430. DOI: 10.1016/j.bbrc.2006.10.054.

Liu Z, Shen J, Carbrey JM, Mukhopadhyay R, Agre P, Rosen BP. 2002. Arsenite transport by mammalian aquaglyceroporins AQP7 and AQP9. Proc Natl Acad Sci U $S$ A. 9 :6053-6058. DOI: 10.1073/pnas.092131899.

Lleras RA, Adrien LR, Smith RV, Brown B, Jivraj N, Keller C, et al. 2011. Hypermethylation of a cluster of kruppel-type zinc finger protein genes on chromosome 19q13 in oropharyngeal squamous cell carcinoma. Am J Pathol. 5 :1965-1974. DOI: 10.1016/j.ajpath.2011.01.049; 10.1016/j.ajpath.2011.01.049.

Lu C, Ward PS, Kapoor GS, Rohle D, Turcan S, Abdel-Wahab O, et al. 2012. IDH mutation impairs histone demethylation and results in a block to cell differentiation. Nature. 7390 :474-478. DOI: 10.1038/nature10860; 10.1038/nature10860.

Majumdar S, Chanda S, Ganguli B, Mazumder DN, Lahiri S, Dasgupta UB. 2010. Arsenic exposure induces genomic hypermethylation. Environ Toxicol. 3 :315-318. DOI: $10.1002 /$ tox.20497.

Marsit CJ, Karagas MR, Danaee H, Liu M, Andrew A, Schned A, et al. 2006. Carcinogen exposure and gene promoter hypermethylation in bladder cancer. Carcinogenesis. 1 :112-116. DOI: 10.1093/carcin/bgi172.

Mass MJ, Wang L. 1997. Arsenic alters cytosine methylation patterns of the promoter of the tumor suppressor gene p53 in human lung cells: A model for a mechanism of carcinogenesis. Mutat Res. 3 :263-277.

Mihara M, Yoshida Y, Tsukamoto T, Inada K, Nakanishi Y, Yagi Y, et al. 2006. Methylation of multiple genes in gastric glands with intestinal metaplasia: A disorder with polyclonal origins. Am J Pathol. 5 :1643-1651. 
Miller WH,Jr, Schipper HM, Lee JS, Singer J, Waxman S. 2002. Mechanisms of action of arsenic trioxide. Cancer Res. 14 :3893-3903.

Minard ME, Jain AK, Barton MC. 2009. Analysis of epigenetic alterations to chromatin during development. Genesis. 8 :559-572. DOI: 10.1002/dvg.20534.

Moore LE, Smith AH, Eng C, Kalman D, DeVries S, Bhargava V, et al. 2002. Arsenicrelated chromosomal alterations in bladder cancer. J Natl Cancer Inst. 22 :16881696.

Mori Y, Olaru AV, Cheng Y, Agarwal R, Yang J, Luvsanjav D, et al. 2011. Novel candidate colorectal cancer biomarkers identified by methylation microarray-based scanning. Endocr Relat Cancer. 4 :465-478. DOI: 10.1530/ERC-11-0083; 10.1530/ERC-11-0083.

Morris MR, Ricketts CJ, Gentle D, McRonald F, Carli N, Khalili H, et al. 2011. Genomewide methylation analysis identifies epigenetically inactivated candidate tumour suppressor genes in renal cell carcinoma. Oncogene. 12 :1390-1401. DOI: 10.1038/onc.2010.525; 10.1038/onc.2010.525.

Mouron SA, Grillo CA, Dulout FN, Golijow CD. 2006. Induction of DNA strand breaks, DNA-protein crosslinks and sister chromatid exchanges by arsenite in a human lung cell line. Toxicol In Vitro. 3 :279-285. DOI: 10.1016/j.tiv.2005.07.005.

Muniz Ortiz JG, Shang J, Catron B, Landero J, Caruso JA, Cartwright IL. 2011. A transgenic drosophila model for arsenic methylation suggests a metabolic rationale for differential dose-dependent toxicity endpoints. Toxicol Sci. 2 :303-311. DOI: $10.1093 /$ tox sci/kfr074.

Nesnow S, Roop BC, Lambert G, Kadiiska M, Mason RP, Cullen WR, et al. 2002. DNA damage induced by methylated trivalent arsenicals is mediated by reactive oxygen species. Chem Res Toxicol. 12 :1627-1634.

Nishiyama H, Gill JH, Pitt E, Kennedy W, Knowles MA. 2001. Negative regulation of G(1)/S transition by the candidate bladder tumour suppressor gene DBCCR1. Oncogene. 23 :2956-2964. DOI: 10.1038/sj.onc.1204432.

Novak P, Jensen TJ, Garbe JC, Stampfer MR, Futscher BW. 2009. Stepwise DNA methylation changes are linked to escape from defined proliferation barriers and mammary epithelial cell immortalization. Cancer Res. 12 :5251-5258. DOI: 10.1158/0008-5472.CAN-08-4977. 
Novak P, Jensen T, Oshiro MM, Watts GS, Kim CJ, Futscher BW. 2008. Agglomerative epigenetic aberrations are a common event in human breast cancer. Cancer Res. 20 :8616-8625. DOI: 10.1158/0008-5472.CAN-08-1419.

Novak P, Jensen T, Oshiro MM, Wozniak RJ, Nouzova M, Watts GS, et al. 2006. Epigenetic inactivation of the HOXA gene cluster in breast cancer. Cancer Res. 22 :10664-10670. DOI: 10.1158/0008-5472.CAN-06-2761.

O'Geen H, Squazzo SL, Iyengar S, Blahnik K, Rinn JL, Chang HY, et al. 2007. Genomewide analysis of KAP1 binding suggests autoregulation of KRAB-ZNFs. PLoS Genet. 6 :e89. DOI: 10.1371/journal.pgen.0030089.

Ohm JE, McGarvey KM, Yu X, Cheng L, Schuebel KE, Cope L, et al. 2007. A stem celllike chromatin pattern may predispose tumor suppressor genes to DNA hypermethylation and heritable silencing. Nat Genet. 2 :237-242. DOI: 10.1038/ng1972.

Oka D, Yamashita S, Tomioka T, Nakanishi Y, Kato H, Kaminishi M, et al. 2009. The presence of aberrant DNA methylation in noncancerous esophageal mucosae in association with smoking history: A target for risk diagnosis and prevention of esophageal cancers. Cancer. 15 :3412-3426. DOI: 10.1002/cncr.24394; 10.1002/cncr.24394.

Okoji RS, Yu RC, Maronpot RR, Froines JR. 2002. Sodium arsenite administration via drinking water increases genome-wide and ha-ras DNA hypomethylation in methyldeficient C57BL/6J mice. Carcinogenesis. 5 :777-785.

Omura N, Li CP, Li A, Hong SM, Walter K, Jimeno A, et al. 2008. Genome-wide profiling of methylated promoters in pancreatic adenocarcinoma. Cancer Biol Ther. 7 :1146-1156.

Ooi SK, Qiu C, Bernstein E, Li K, Jia D, Yang Z, et al. 2007. DNMT3L connects unmethylated lysine 4 of histone H3 to de novo methylation of DNA. Nature. 7154 :714-717. DOI: 10.1038/nature05987.

Paez-Espino D, Tamames J, de Lorenzo V, Canovas D. 2009. Microbial responses to environmental arsenic. Biometals. 1 :117-130. DOI: 10.1007/s10534-008-9195-y.

Park JH, Kim EJ, Jang HY, Shim H, Lee KK, Jo HJ, et al. 2008. Combination treatment with arsenic trioxide and sulindac enhances apoptotic cell death in lung cancer cells via activation of oxidative stress and mitogen-activated protein kinases. Oncol Rep. 2 :379-384. 
Paton GR, Allison AC. 1972. Chromosome damage in human cell cultures induced by metal salts. Mutat Res. $3: 332-336$.

Petrick JS, Ayala-Fierro F, Cullen WR, Carter DE, Vasken Aposhian H. 2000. Monomethylarsonous acid (MMA(III)) is more toxic than arsenite in chang human hepatocytes. Toxicol Appl Pharmacol. 2 :203-207. DOI: 10.1006/taap.1999.8872.

Petzoldt JL, Leigh IM, Duffy PG, Sexton C, Masters JR. 1995. Immortalisation of human urothelial cells. Urol Res. $6: 377-380$.

Pi J, Qu W, Reece JM, Kumagai Y, Waalkes MP. 2003. Transcription factor Nrf2 activation by inorganic arsenic in cultured keratinocytes: Involvement of hydrogen peroxide. Exp Cell Res. 2 :234-245.

Pilsner JR, Liu X, Ahsan H, Ilievski V, Slavkovich V, Levy D, et al. 2009. Folate deficiency, hyperhomocysteinemia, low urinary creatinine, and hypomethylation of leukocyte DNA are risk factors for arsenic-induced skin lesions. Environ Health Perspect. 2 :254-260. DOI: 10.1289/ehp.11872.

Pilsner JR, Liu X, Ahsan H, Ilievski V, Slavkovich V, Levy D, et al. 2007. Genomic methylation of peripheral blood leukocyte DNA: Influences of arsenic and folate in bangladeshi adults. Am J Clin Nutr. 4 :1179-1186.

Portela A, Esteller M. 2010. Epigenetic modifications and human disease. Nat Biotechnol. 10 :1057-1068. DOI: 10.1038/nbt.1685.

Quenneville S, Turelli P, Bojkowska K, Raclot C, Offner S, Kapopoulou A, et al. 2012. The KRAB-ZFP/KAP1 system contributes to the early embryonic establishment of site-specific DNA methylation patterns maintained during development. Cell Rep. 4 :766-773. DOI: 10.1016/j.celrep.2012.08.043; 10.1016/j.celrep.2012.08.043.

R_Development_Core_Team. 2010. R: A language and environment for statistical computing.

Rahman A, Persson LA, Nermell B, El Arifeen S, Ekstrom EC, Smith AH, et al. 2010. Arsenic exposure and risk of spontaneous abortion, stillbirth, and infant mortality. Epidemiology. 6 :797-804. DOI: 10.1097/EDE.0b013e3181f56a0d; 10.1097/EDE.0b013e3181f56a0d.

Ralph SJ. 2008. Arsenic-based antineoplastic drugs and their mechanisms of action. Met Based Drugs. 260146. DOI: 10.1155/2008/260146. 
Ramirez T, Brocher J, Stopper H, Hock R. 2008. Sodium arsenite modulates histone acetylation, histone deacetylase activity and HMGN protein dynamics in human cells. Chromosoma. 2 :147-157. DOI: 10.1007/s00412-007-0133-5.

Rauch T, Wang Z, Zhang X, Zhong X, Wu X, Lau SK, et al. 2007. Homeobox gene methylation in lung cancer studied by genome-wide analysis with a microarraybased methylated CpG island recovery assay. Proc Natl Acad Sci U S A. 13 :55275532. DOI: $10.1073 /$ pnas.0701059104.

Reichard JF, Puga A. 2010. Effects of arsenic exposure on DNA methylation and epigenetic gene regulation. Epigenomics. 1 :87-104. DOI: 10.2217/epi.09.45.

Reichard JF, Schnekenburger M, Puga A. 2007. Long term low-dose arsenic exposure induces loss of DNA methylation. Biochem Biophys Res Commun. 1 :188-192. DOI: 10.1016/j.bbrc.2006.11.001.

Ren X, McHale CM, Skibola CF, Smith AH, Smith MT, Zhang L. 2011. An emerging role for epigenetic dysregulation in arsenic toxicity and carcinogenesis. Environ Health Perspect. 1 :11-19. DOI: 10.1289/ehp.1002114.

Reya T, Morrison SJ, Clarke MF, Weissman IL. 2001. Stem cells, cancer, and cancer stem cells. Nature. 6859 : 105-111. DOI: 10.1038/35102167.

Ringrose L, Paro R. 2007. Polycomb/trithorax response elements and epigenetic memory of cell identity. Development. 2 :223-232. DOI: 10.1242/dev.02723.

Romanish MT, Cohen CJ, Mager DL. 2010. Potential mechanisms of endogenous retroviral-mediated genomic instability in human cancer. Semin Cancer Biol. 4 :246253. DOI: 10.1016/j.semcancer.2010.05.005; 10.1016/j.semcancer.2010.05.005.

Rossi MR, Masters JR, Park S, Todd JH, Garrett SH, Sens MA, et al. 2001. The immortalized UROtsa cell line as a potential cell culture model of human urothelium. Environ Health Perspect. 8 :801-808.

Rossman TG. 2003. Mechanism of arsenic carcinogenesis: An integrated approach. Mutat Res. 1-2 :37-65.

Rossman TG, Uddin AN, Burns FJ, Bosland MC. 2001. Arsenite is a cocarcinogen with solar ultraviolet radiation for mouse skin: An animal model for arsenic carcinogenesis. Toxicol Appl Pharmacol. 1 :64-71. DOI: 10.1006/taap.2001.9277.

Rossman TG, Stone D, Molina M, Troll W. 1980. Absence of arsenite mutagenicity in E coli and chinese hamster cells. Environ Mutagen. 3 :371-379. 
Rowe HM, Friedli M, Offner S, Verp S, Mesnard D, Marquis J, et al. 2013. De novo DNA methylation of endogenous retroviruses is shaped by KRAB-ZFPs/KAP1 and ESET. Development. 3 :519-529. DOI: 10.1242/dev.087585; 10.1242/dev.087585.

Rowe HM, Trono D. 2011. Dynamic control of endogenous retroviruses during development. Virology. 2 :273-287. DOI: 10.1016/j.virol.2010.12.007; 10.1016/j.virol.2010.12.007.

Rowe HM, Jakobsson J, Mesnard D, Rougemont J, Reynard S, Aktas T, et al. 2010. KAP1 controls endogenous retroviruses in embryonic stem cells. Nature. 7278 :237240. DOI: 10.1038/nature08674; 10.1038/nature08674.

Said N, Frierson HF,Jr, Chernauskas D, Conaway M, Motamed K, Theodorescu D. 2009. The role of SPARC in the TRAMP model of prostate carcinogenesis and progression. Oncogene. 39 :3487-3498. DOI: 10.1038/onc.2009.205; 10.1038/onc.2009.205.

Schlawicke Engstrom K, Nermell B, Concha G, Stromberg U, Vahter M, Broberg K. 2009. Arsenic metabolism is influenced by polymorphisms in genes involved in onecarbon metabolism and reduction reactions. Mutat Res. 1-2 :4-14. DOI: 10.1016/j.mrfmmm.2008.07.003.

Schlesinger Y, Straussman R, Keshet I, Farkash S, Hecht M, Zimmerman J, et al. 2007. Polycomb-mediated methylation on Lys 27 of histone $\mathrm{H} 3$ pre-marks genes for de novo methylation in cancer. Nat Genet. 2 :232-236. DOI: 10.1038/ng1950.

Sciandrello G, Caradonna F, Mauro M, Barbata G. 2004. Arsenic-induced DNA hypomethylation affects chromosomal instability in mammalian cells. Carcinogenesis. 3 :413-417. DOI: 10.1093/carcin/bgh029.

Sens DA, Park S, Gurel V, Sens MA, Garrett SH, Somji S. 2004. Inorganic cadmiumand arsenite-induced malignant transformation of human bladder urothelial cells. Toxicol Sci. 1 :56-63. DOI: 10.1093/toxsci/kfh086.

Severson PL, Tokar EJ, Vrba L, Waalkes MP, Futscher BW. 2012. Agglomerates of aberrant DNA methylation are associated with toxicant-induced malignant transformation. Epigenetics. 11 :1238-1248. DOI: 10.4161/epi.22163; 10.4161/epi.22163.

Shao JY, Huang XM, Yu XJ, Huang LX, Wu QL, Xia JC, et al. 2001. Loss of heterozygosity and its correlation with clinical outcome and epstein-barr virus infection in nasopharyngeal carcinoma. Anticancer Res. 4B :3021-3029. 
Sharma S, Kelly TK, Jones PA. 2010. Epigenetics in cancer. Carcinogenesis. 1 :27-36. DOI: $10.1093 /$ carcin/bgp220.

Shi H, Shi X, Liu KJ. 2004. Oxidative mechanism of arsenic toxicity and carcinogenesis. Mol Cell Biochem. 1-2 :67-78.

Smith AH, Marshall G, Liaw J, Yuan Y, Ferreccio C, Steinmaus C. 2012. Mortality in young adults following in utero and childhood exposure to arsenic in drinking water. Environ Health Perspect. 11 :1527-1531. DOI: 10.1289/ehp.1104867; 10.1289/ehp.1104867.

Smith AH, Marshall G, Yuan Y, Liaw J, Ferreccio C, Steinmaus C. 2011. Evidence from chile that arsenic in drinking water may increase mortality from pulmonary tuberculosis. Am J Epidemiol. 4 :414-420. DOI: 10.1093/aje/kwq383.

Smith AH, Marshall G, Yuan Y, Ferreccio C, Liaw J, von Ehrenstein O, et al. 2006. Increased mortality from lung cancer and bronchiectasis in young adults after exposure to arsenic in utero and in early childhood. Environ Health Perspect. 8 :1293-1296. DOI: 10.1289/ehp.8832.

Smith AH, Lingas EO, Rahman M. 2000. Contamination of drinking-water by arsenic in bangladesh: A public health emergency. Bull World Health Organ. 9 :1093-1103.

Smith AH, Goycolea M, Haque R, Biggs ML. 1998. Marked increase in bladder and lung cancer mortality in a region of northern chile due to arsenic in drinking water. Am J Epidemiol. 7 :660-669.

Smyth GK. 2005. Limma: Linear models for microarray data. 397-420.

SOMMERS SC, MCMANUS RG. 1953. Multiple arsenical cancers of skin and internal organs. Cancer. 2 :347-359.

Stampfer MR, Yaswen P. 2003. Human epithelial cell immortalization as a step in carcinogenesis. Cancer Lett. 2 :199-208.

Stampfer MR, Bartley JC. 1985. Induction of transformation and continuous cell lines from normal human mammary epithelial cells after exposure to benzo[a]pyrene. Proc Natl Acad Sci U S A. 8 :2394-2398.

Steinmaus CM, Ferreccio C, Romo JA, Yuan Y, Cortes S, Marshall G, et al. 2013. Drinking water arsenic in northern chile: High cancer risks 40 years after exposure cessation. Cancer Epidemiol Biomarkers Prev. 4 :623-630. DOI: 10.1158/10559965.EPI-12-1190; 10.1158/1055-9965.EPI-12-1190. 
Stone KR, Mickey DD, Wunderli H, Mickey GH, Paulson DF. 1978. Isolation of a human prostate carcinoma cell line (DU 145). Int J Cancer. 3 :274-281.

Straif K, Benbrahim-Tallaa L, Baan R, Grosse Y, Secretan B, El Ghissassi F, et al. 2009. A review of human carcinogens--part C: Metals, arsenic, dusts, and fibres. Lancet Oncol. 5 :453-454.

Stransky N, Vallot C, Reyal F, Bernard-Pierrot I, de Medina SG, Segraves R, et al. 2006. Regional copy number-independent deregulation of transcription in cancer. Nat Genet. 12 :1386-1396. DOI: 10.1038/ng1923.

Suzuki MM, Bird A. 2008. DNA methylation landscapes: Provocative insights from epigenomics. Nat Rev Genet. 6 :465-476. DOI: 10.1038/nrg2341.

Takahashi M, Barrett JC, Tsutsui T. 2002. Transformation by inorganic arsenic compounds of normal syrian hamster embryo cells into a neoplastic state in which they become anchorage-independent and cause tumors in newborn hamsters. Int $J$ Cancer. 5 :629-634. DOI: 10.1002/ijc.10407.

Tan LB, Chen KT, Guo HR. 2008. Clinical and epidemiological features of patients with genitourinary tract tumour in a blackfoot disease endemic area of taiwan. BJU Int. 1 :48-54. DOI: 10.1111/j.1464-410X.2008.07565.x.

Terry MB, Delgado-Cruzata L, Vin-Raviv N, Wu HC, Santella RM. 2011. DNA methylation in white blood cells: Association with risk factors in epidemiologic studies. Epigenetics. 7 :.

Thomas DJ. 2007. Molecular processes in cellular arsenic metabolism. Toxicol Appl Pharmacol. 3 :365-373. DOI: 10.1016/j.taap.2007.02.007.

Thomas JH, Schneider S. 2011. Coevolution of retroelements and tandem zinc finger genes. Genome Res. 11 :1800-1812. DOI: 10.1101/gr.121749.111; 10.1101/gr.121749.111.

Tokar EJ, Diwan BA, Ward JM, Delker DA, Waalkes MP. 2011a. Carcinogenic effects of "whole-life" exposure to inorganic arsenic in CD1 mice. Toxicol Sci. 1 :73-83. DOI: $10.1093 /$ toxsci/kfq315.

Tokar EJ, Qu W, Waalkes MP. 2011b. Arsenic, stem cells, and the developmental basis of adult cancer. Toxicol Sci. S192-203. DOI: 10.1093/toxsci/kfq342.

Trojer P, Reinberg D. 2007. Facultative heterochromatin: Is there a distinctive molecular signature? Mol Cell. 1 :1-13. DOI: 10.1016/j.molcel.2007.09.011. 
Tseng WP. 1977. Effects and dose--response relationships of skin cancer and blackfoot disease with arsenic. Environ Health Perspect. 109-119.

Tsuda H, Takarabe T, Okada S, Uchida H, Kasamatsu T, Yamada T, et al. 2002. Different pattern of loss of heterozygosity among endocervical-type adenocarcinoma, endometrioid-type adenocarcinoma and adenoma malignum of the uterine cervix. Int J Cancer. 5 :713-717.

Turcan S, Rohle D, Goenka A, Walsh LA, Fang F, Yilmaz E, et al. 2012. IDH1 mutation is sufficient to establish the glioma hypermethylator phenotype. Nature. $7390: 479$ 483. DOI: $10.1038 /$ nature10866; 10.1038/nature10866.

Turk PW, Laayoun A, Smith SS, Weitzman SA. 1995. DNA adduct 8-hydroxyl-2'deoxyguanosine (8-hydroxyguanine) affects function of human DNA methyltransferase. Carcinogenesis. 5 :1253-1255.

Tzeng CC, Liu HS, Li C, Jin YT, Chen RM, Yang WH, et al. 1996. Characterization of two urothelium cancer cell lines derived from a blackfoot disease endemic area in taiwan. Anticancer Res. 4A :1797-1804.

Ummanni R, Jost E, Braig M, Lohmann F, Mundt F, Barett C, et al. 2011. Ubiquitin carboxyl-terminal hydrolase 1 (UCHL1) is a potential tumour suppressor in prostate cancer and is frequently silenced by promoter methylation. Mol Cancer. 129-459810-129. DOI: 10.1186/1476-4598-10-129; 10.1186/1476-4598-10-129.

US Environmental Protection Agency. 2001. National primary drinking water regulations; arsenic and clarifications to compliance and new source contaminants monitoring; final rule. Fed Regist. 66 :6976.

Uthus EO, Davis C. 2005. Dietary arsenic affects dimethylhydrazine-induced aberrant crypt formation and hepatic global DNA methylation and DNA methyltransferase activity in rats. Biol Trace Elem Res. 2 :133-145. DOI: 10.1385/BTER:103:2:133.

Vahidnia A, van der Voet GB, de Wolff FA. 2007. Arsenic neurotoxicity--a review. Hum Exp Toxicol. 10 :823-832. DOI: 10.1177/0960327107084539.

Vahter M. 2008. Health effects of early life exposure to arsenic. Basic Clin Pharmacol Toxicol. 2 :204-211. DOI: 10.1111/j.1742-7843.2007.00168.x.

Vahter M, Couch R, Nermell B, Nilsson R. 1995. Lack of methylation of inorganic arsenic in the chimpanzee. Toxicol Appl Pharmacol. 2 :262-268. DOI: 10.1006/taap.1995.1150. 
Vahter M, Marafante E. 1985. Reduction and binding of arsenate in marmoset monkeys. Arch Toxicol. 2 :119-124.

Valenzuela OL, Borja-Aburto VH, Garcia-Vargas GG, Cruz-Gonzalez MB, GarciaMontalvo EA, Calderon-Aranda ES, et al. 2005. Urinary trivalent methylated arsenic species in a population chronically exposed to inorganic arsenic. Environ Health Perspect. 3 :250-254.

Villa-Bellosta R, Sorribas V. 2010. Arsenate transport by sodium/phosphate cotransporter type IIb. Toxicol Appl Pharmacol. 1 :36-40. DOI: 10.1016/j.taap.2010.05.012.

Vire E, Brenner C, Deplus R, Blanchon L, Fraga M, Didelot C, et al. 2006. The polycomb group protein EZH2 directly controls DNA methylation. Nature. 7078 :871-874. DOI: $10.1038 /$ nature04431.

Vogel MJ, Guelen L, de Wit E, Peric-Hupkes D, Loden M, Talhout W, et al. 2006. Human heterochromatin proteins form large domains containing KRAB-ZNF genes. Genome Res. 12 :1493-1504. DOI: 10.1101/gr.5391806.

Vrba L, Garbe JC, Stampfer MR, Futscher BW. 2011. Epigenetic regulation of normal human mammary cell type-specific miRNAs. Genome Res. 12 :2026-2037. DOI: 10.1101/gr.123935.111.

Waalkes MP, Liu J, Germolec DR, Trempus CS, Cannon RE, Tokar EJ, et al. 2008. Arsenic exposure in utero exacerbates skin cancer response in adulthood with contemporaneous distortion of tumor stem cell dynamics. Cancer Res. 20 :82788285. DOI: 10.1158/0008-5472.CAN-08-2099.

Waalkes MP, Liu J, Chen H, Xie Y, Achanzar WE, Zhou YS, et al. 2004. Estrogen signaling in livers of male mice with hepatocellular carcinoma induced by exposure to arsenic in utero. J Natl Cancer Inst. 6 :466-474.

Waalkes MP, Ward JM, Liu J, Diwan BA. 2003. Transplacental carcinogenicity of inorganic arsenic in the drinking water: Induction of hepatic, ovarian, pulmonary, and adrenal tumors in mice. Toxicol Appl Pharmacol. 1 :7-17.

Wallace DC, Fan W. 2010. Energetics, epigenetics, mitochondrial genetics. Mitochondrion. 1 :12-31. DOI: 10.1016/j.mito.2009.09.006.

Wang Z, Zhao Y, Smith E, Goodall GJ, Drew PA, Brabletz T, et al. 2011. Reversal and prevention of arsenic-induced human bronchial epithelial cell malignant transformation by microRNA-200b. Toxicol Sci. 1 :110-122. DOI: 10.1093/toxsci/kfr029. 
Webber MM, Quader ST, Kleinman HK, Bello-DeOcampo D, Storto PD, Bice G, et al. 2001. Human cell lines as an in vitro/in vivo model for prostate carcinogenesis and progression. Prostate. 1 :1-13. DOI: 10.1002/pros.1041.

Weber M, Davies JJ, Wittig D, Oakeley EJ, Haase M, Lam WL, et al. 2005.

Chromosome-wide and promoter-specific analyses identify sites of differential DNA methylation in normal and transformed human cells. Nat Genet. 8 :853-862. DOI: $10.1038 /$ ng1598.

Weitzman SA, Turk PW, Milkowski DH, Kozlowski K. 1994. Free radical adducts induce alterations in DNA cytosine methylation. Proc Natl Acad Sci U S A. 4 :12611264.

Wen B, Wu H, Shinkai Y, Irizarry RA, Feinberg AP. 2009. Large histone H3 lysine 9 dimethylated chromatin blocks distinguish differentiated from embryonic stem cells. Nat Genet. 2 :246-250. DOI: 10.1038/ng.297.

WHO. 1993. Guidelines for drinking-water quality<br/>. Geneva.

Widschwendter M, Fiegl H, Egle D, Mueller-Holzner E, Spizzo G, Marth C, et al. 2007. Epigenetic stem cell signature in cancer. Nat Genet. 2 :157-158. DOI: $10.1038 /$ ng1941.

Wnek SM, Jensen TJ, Severson PL, Futscher BW, Gandolfi AJ. 2010. Monomethylarsonous acid produces irreversible events resulting in malignant transformation of a human bladder cell line following 12 weeks of low-level exposure. Toxicol Sci. 1 :44-57. DOI: 10.1093/toxsci/kfq106.

Wong SY, Crowley D, Bronson RT, Hynes RO. 2008. Analyses of the role of endogenous SPARC in mouse models of prostate and breast cancer. Clin Exp Metastasis. 2 :109-118. DOI: 10.1007/s10585-007-9126-2.

Wu DD, Xiao YF, Geng Y, Hou J. 2010a. Antitumor effect and mechanisms of arsenic trioxide on subcutaneously implanted human gastric cancer in nude mice. Cancer Genet Cytogenet. 2 :90-96. DOI: 10.1016/j.cancergencyto.2009.12.015.

Wu X, Rauch TA, Zhong X, Bennett WP, Latif F, Krex D, et al. 2010b. CpG island hypermethylation in human astrocytomas. Cancer Res. 7 :2718-2727. DOI: 10.1158/0008-5472.CAN-09-3631.

Xiang Z, Yuan W, Luo N, Wang Y, Tan K, Deng Y, et al. 2006. A novel human zinc finger protein ZNF540 interacts with MVP and inhibits transcriptional activities of the ERK signal pathway. Biochem Biophys Res Commun. 1 :288-296. DOI: 10.1016/j.bbrc.2006.06.076. 
Xiao M, Yang H, Xu W, Ma S, Lin H, Zhu H, et al. 2012. Inhibition of alpha-KGdependent histone and DNA demethylases by fumarate and succinate that are accumulated in mutations of FH and SDH tumor suppressors. Genes Dev. 12 :13261338. DOI: $10.1101 / \mathrm{gad} .191056 .112 ; 10.1101 / \mathrm{gad} .191056 .112$.

Xie Y, Trouba KJ, Liu J, Waalkes MP, Germolec DR. 2004. Biokinetics and subchronic toxic effects of oral arsenite, arsenate, monomethylarsonic acid, and dimethylarsinic acid in v-ha-ras transgenic (tg.AC) mice. Environ Health Perspect. 12 :1255-1263.

Yamashita S, Tsujino Y, Moriguchi K, Tatematsu M, Ushijima T. 2006. Chemical genomic screening for methylation-silenced genes in gastric cancer cell lines using 5-aza-2'-deoxycytidine treatment and oligonucleotide microarray. Cancer Sci. 1 :6471. DOI: 10.1111/j.1349-7006.2006.00136.x.

Yang H, Yuan W, Wang Y, Zhu C, Liu B, Wang Y, et al. 2005. ZNF649, a novel kruppel type zinc-finger protein, functions as a transcriptional suppressor. Biochem Biophys Res Commun. 1 :206-215. DOI: 10.1016/j.bbrc.2005.05.101.

Yeh KY, Chang JW, Li YY, Wang CH, Wang HM. 2011. Tumor growth inhibition of metastatic nasopharyngeal carcinoma cell lines by low dose of arsenic trioxide via alteration of cell cycle progression and induction of apoptosis. Head Neck. 5 :734742. DOI: 10.1002/hed.21535; 10.1002/hed.21535.

Yu RC, Hsu KH, Chen CJ, Froines JR. 2000. Arsenic methylation capacity and skin cancer. Cancer Epidemiol Biomarkers Prev. 11 :1259-1262.

Zhang AH, Bin HH, Pan XL, Xi XG. 2007. Analysis of p16 gene mutation, deletion and methylation in patients with arseniasis produced by indoor unventilated-stove coal usage in guizhou, china. J Toxicol Environ Health A. 11 :970-975. DOI: 10.1080/15287390701290808.

Zhao CQ, Young MR, Diwan BA, Coogan TP, Waalkes MP. 1997. Association of arsenic-induced malignant transformation with DNA hypomethylation and aberrant gene expression. Proc Natl Acad Sci U S A. 20 :10907-10912.

Zhao F, Severson P, Pacheco S, Futscher BW, Klimecki WT. 2013. Arsenic exposure induces the warburg effect in cultured human cells. Toxicol Appl Pharmacol. DOI: 10.1016/j.taap.2013.04.020; 10.1016/j.taap.2013.04.020.

Zhou X, Sun X, Cooper KL, Wang F, Liu KJ, Hudson LG. 2011. Arsenite interacts selectively with zinc finger proteins containing $\mathrm{C} 3 \mathrm{H} 1$ or $\mathrm{C} 4$ motifs. J Biol Chem. 26 :22855-22863. DOI: 10.1074/jbc.M111.232926. 
Zhou X, Li Q, Arita A, Sun H, Costa M. 2009. Effects of nickel, chromate, and arsenite on histone 3 lysine methylation. Toxicol Appl Pharmacol. 1 :78-84. DOI: 10.1016/j.taap.2009.01.009.

Zhou X, Sun H, Ellen TP, Chen H, Costa M. 2008. Arsenite alters global histone H3 methylation. Carcinogenesis. 9 :1831-1836. DOI: 10.1093/carcin/bgn063.

Zykova TA, Zhu F, Lu C, Higgins L, Tatsumi Y, Abe Y, et al. 2006. Lymphokineactivated killer T-cell-originated protein kinase phosphorylation of histone $\mathrm{H} 2 \mathrm{AX}$ prevents arsenite-induced apoptosis in RPMI7951 melanoma cells. Clin Cancer Res. 23 :6884-6893. DOI: 10.1158/1078-0432.CCR-06-0410. 